
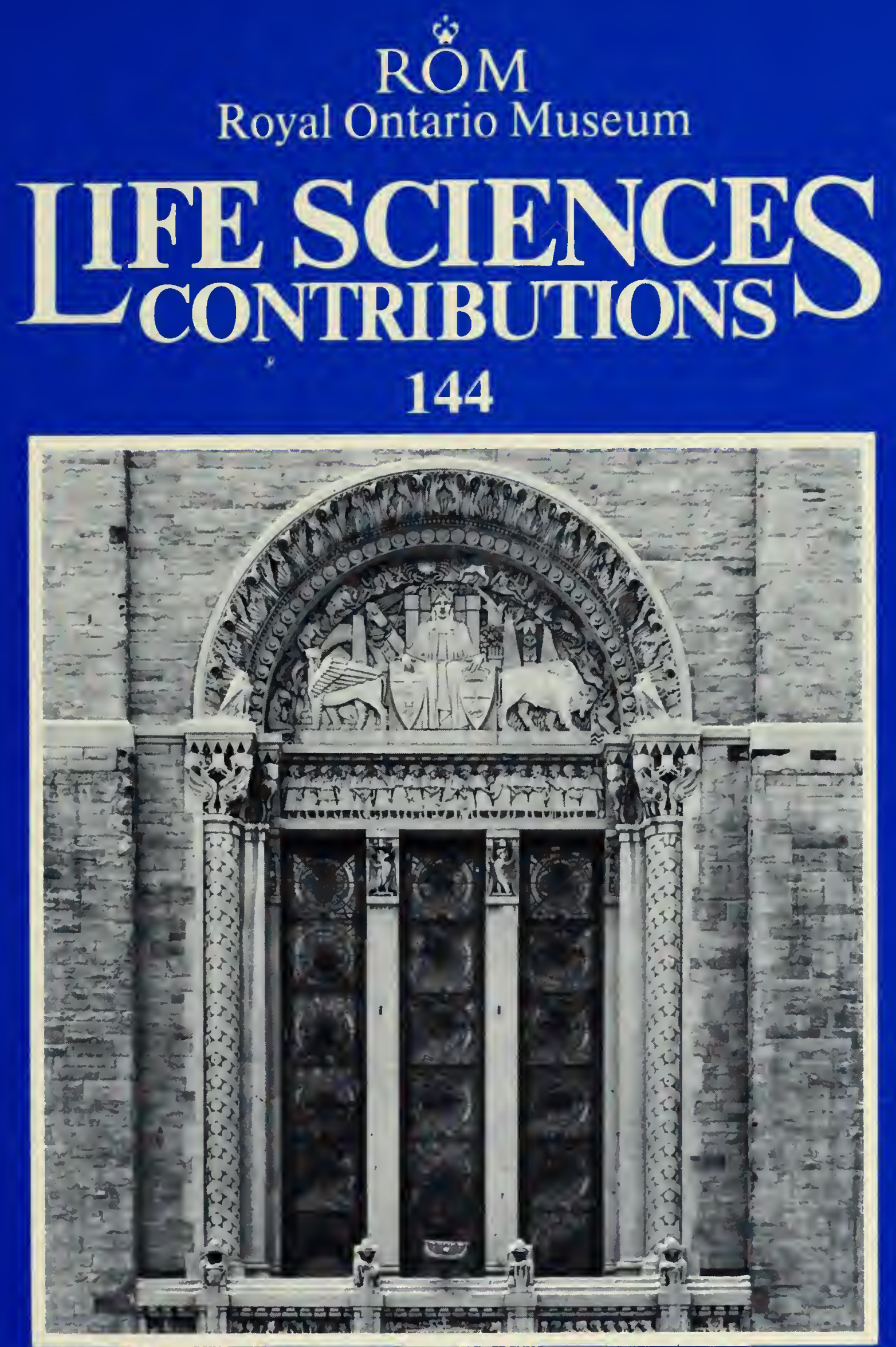

\title{
Revision of the Caddisfly Genus Psilotreta (Trichoptera: Odontoceridae)
}

\author{
C. R. Parker \\ and \\ G. B. Wiggins
}




\section{ROYAL ONTARIO MUSEUM LIFE SCIENCES PUBLICATIONS INSTRUCTIONS TO AUTHORS}

Authors should prepare their manuscripts carefully according to the following instructions; failure to do so will result in the manuscript's being returned to the author for revision. All manuscripts are considered on the understanding that they are not currently offered for publication elsewhere.

1. General Papers for publication are accepted from ROM staff members and research associates, and from researchers reporting on work done with ROM collections. Monographs on the flora and/or fauna of Ontario may be considered for publication by authors not affiliated with the ROM. Financial contributions towards publication will be welcome. Authors are expected to write clearly and concisely and to omit any material not essential for an understanding of the main theme of the paper.

2. Format Manuscripts (including captions, synonymies, literature cited, and tables) should be typed with double space on $11^{\prime \prime} \times 8 \frac{1}{2}$ " paper with a $1 \frac{1 / 2}{2}$ margin on all sides. Three xerox copies should be submitted to the Senior Editor of the Editorial Board; the original should be retained by the author(s). The submission should include a separate sheet giving the author(s) names and affiliations, the title of the publication, the series for which it is submitted, the number of typed pages, the number of tables, and the number of plates or figures. Manuscripts should normally be organized in the following order: Contents, Abstract, Introduction, Materials and Methods, Results, Discussion, Conclusions, Summary (if manuscript is long), Acknowledgements, Appendices, and Literature Cited. Authors are encouraged to include foreign-language translations of the Summary, if appropriate. Main headings should be centred; subheadings should be left-justified to the text margin. The first line of the first paragraph in each new section should not be indented. Literature citations in the text should be in the form "Jones (1972)" or "(Jones, 1972)" or "(Smith, 1960:71-79, fig. 17)".

3. Standard Sources The primary authority on questions of format and style is Guide to Authors, available from ROM Publication Services. For matters not covered in the Guide, consult CBE Style Manual (Fifth Edition). Other standard sources are as follows: for
English spelling, The Concise Oxford Dictionary; for Canadian place names and coordinates, Canada Gazetteer Atlas; for the spelling of geographic names, The Times Atlas.

4. Abstract All papers must be preceded by a short, factual abstract, about one per cent of the text in length. The abstract may be followed by four to six key words in parentheses.

5. Taxonomy The name of a taxon should be given in full in headings, at the beginnings of paragraphs, and at its first occurrence in the text. Give the authority and date, if appropriate, with the first mention of each taxon, but not thereafter. Taxonomic papers, particularly synonymies, should follow the layout in Life Sciences Contributions beginning with No. 136. International Codes of Biological Nomenclature must be followed.

6. Literature Cited A complete list of references, in alphabetical order of authors, must be given at the end of the paper. When two or more works of one author are cited, they should be listed chronologically. The names of journals should not be abbreviated. For correct bibliographic form, see Life Sciences Contributions beginning with No. 136.

7. Tables All tables should be typed on separate sheets and numbered consecutively in arabic numerals in the order of their first mention in the text. Mark the location of each table in the margin of the text.

8. Plates, Figures, and Text-figures Illustrations may be designated according to the conventions of the author's discipline; in some disciplines grouped photographs of scientific subject matter are commonly termed Plates, while line drawings and locality and other illustrations that occupy a full page or less are Text-figures. Usage must be consistent throughout the paper. A full-page illustration for a Contribution, with its caption, should be sized to fit an area of $17.3 \times$ $22.75 \mathrm{~cm}$; for Occasional Papers, the area is $14.1 \times$ $21.2 \mathrm{~cm}$. If captions are lengthy, they may be placed on the facing page. A scale or magnification factor should be included. Authors are reminded that when illustrations are reduced magnification factors will change, and that they are responsible for the conversion. For details, see Guide to Authors. 


\section{Revision of the Caddisfly Genus Psilotreta (Trichoptera: Odontoceridae)}


. 
LIFE SCIENCES CONTRIBUTIONS 144

\title{
Revision of the Caddisfly Genus Psilotreta (Trichoptera: Odontoceridae)
}

\author{
C. R. Parker \\ and \\ G. B. Wiggins
}

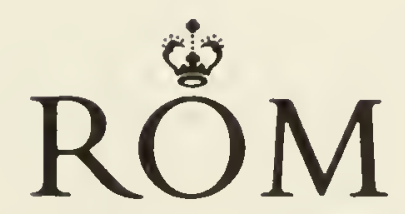

ROYAL ONTARIO MUSEUM 
The Royal Ontario Museum publishes three series in the Life Sciences. CONTRIBUTIONS: a numbered series of original scientific publications.

OCCASIONAL PAPERS: a numbered series of original scientific publications, primarily short and of taxonomic significance.

MISCELLANEOUS PUBLICATIONS: an unnumbered series on a variety of subjects.

All manuscripts considered for publication are subject to the scrutiny and editorial policies of the Life Sciences Editorial Board, and to independent refereeing by two or more persons, other than Museum staff, who are authorities in the particular field involved.

\section{LIFE SCIENCES EDITORIAL BOARD}

Senior editor: E. J. Crossman

Editor: Judith L. Eger

Editor: D. C. Darling

External editor: C. S. Churcher

Manuscript editor: E. J. Crossman

Production editor: J. E. Hawken

Charles R. Parker was a postdoctoral associate, Department of Entomology, Royal Ontario Museum, 100 Queen's Park, Toronto, Ontario M5S 2C6 and Department of Zoology, University of Toronto, Toronto, Canada; current address is National Park Service, Great Smoky Mountains National Park, Rt. 2, Box 260, Gatlinburg, Tennessee 37738, USA.

Glenn B. Wiggins is Curator-in-charge, Department of Entomology, Royal Ontario Museum, 100 Queen's Park, Toronto, Ontario M5S 2C6; and Professor, Department of Zoology, University of Toronto, Toronto, Canada.

\footnotetext{
Canadian Cataloguing in Publication Data

Parker, C. R. (Charles R.), 1948-

Revision of the caddisfly genus Psilotreta

(Trichoptera: Odontoceridae)

(Life sciences contributions, ISSN 0384-8159; I44)

Bibliography: $p$.

ISBN 0-88854-332-8

1. Caddis-flies - North America - Identification.

2. Caddis-flies - Asia - Identification.

I. Wiggins, Glenn B. II. Royal Ontario Museum.

III. Title. IV. Series.
}

QL518.04P37 $1987 \quad 595.7^{\prime} 45 \quad$ C87-095015-0

Publication date: I5 November 1987

ISBN 0-88854-332-8

ISSN 0384-8159

(C) Royal Ontario Museum, 1987

J00 Queen's Park, Toronto, Canada M5S 2C6

PRINTED AND BOUND IN CANADA AT THE ALGER PRESS 


\title{
Contents
}

\author{
Abstract 1 \\ Introduction 1 \\ Materials and Methods I \\ Locations of Specimens Examined 2 \\ Genus Psilotreta Banks 3 \\ North American Psilotreta 9 \\ Key to Adults of North American Species 9 \\ Key to Larvae of North American Species $\quad 10$ \\ Psilotreta indecisa Group 11 \\ Psilotreta indecisa (Walker) 11 \\ Psilotreta frontalis Banks 13 \\ Psilotreta labida Ross $\quad 18$ \\ Psilotreta rufa (Hagen) 21 \\ Psilotreta rossi Wallace 23 \\ Psilotreta amera (Ross) 25 \\ Asian Psilotreta 32 \\ Key to Males of Asian Psilotreta 32 \\ Psilotreta japonica (Banks) 34 \\ Psilotreta chinensis Banks 34 \\ Psilotreta kisoensis Iwata 35 \\ Psilotreta locumtenens Botoşăneanu 36 \\ Psilotreta falcula Botoşăneanu $\quad 40$ \\ Psilotreta quadrata Schmid $\quad 40$ \\ Psilotreta schmidi sp. nov. 41 \\ Psilotreta assamensis sp. nov. 41 \\ Psilotreta sp. $\quad 43$ \\ Psilotreta kwantungensis Ulmer 45 \\ Psilotreta trispinosa Schmid 47 \\ Species Not Examined 47 \\ Phylogenetic and Biogeographic Considerations 48 \\ List of Species $\quad 50$ \\ Acknowledgements 51 \\ Literature Cited 53
}




\section{Digitized by the Internet Archive in 2011 with funding from University of Toronto}




\title{
Revision of the Caddisfly Genus Psilotreta (Trichoptera: Odontoceridae)
}

\begin{abstract}
Twenty species of Psilotreta are recognized, 6 from eastern North America and 14 from Asia. Adults and larvae are described and illustrated for the North American species, and keys are provided. For the Asian species, males and females of $P$. japonica (Banks), $P$. chinensis Banks, and $P$. kwantungensis Ulmer, and larvae of $P$. kisoensis Iwata are described and illustrated; observations are made on adults of $P$. falcula Botoşăneanu, $P$. locumtenens Botoşăneanu, $P$. quadrata Schmid, and $P$.trispinosa Schmid, and on larvae and pupae of $P$. locumtenens. Two new species are described from eastern India: $P$. schmidi sp. nov. and $P$. assamensis sp. nov. A key to the males of the Asian species is presented. The larva and pupa of an undetermined species from India are described. Phylogenetic analysis indicates that the North American species form a monophyletic group, and a cladogram based on characters of adults and larvae is presented for them. Possible relationships among the Asian species are suggested based on characters of the males.
\end{abstract}

\section{Introduction}

Caddisflies of the genus Psilotreta Banks, 1899, occur in cool running-water habitats in Asia and eastern North America. Adults are cryptic and infrequently collected, but the larvae and pupae are often found in large numbers because of the gregarious habit in some species of fastening the cases for pupation in layers to the undersides of rocks. Twenty species of Psilotreta are recognized, 6 from North America and 14 from Asia. The larva of only 1 North American species, $P$. labida Ross, has been described (by Lloyd, 1921, as $P$. frontalis Banks), and that of another species, $P$. rufa (Hagen), has been illustrated (by Wiggins, 1977, as $P$. sp.). Ross (1944) provided keys to males of 5 North American species, but the females and larvae have not yet been distinguished. The purpose of this study was to make North American species of Psilotreta identifiable in larval and other stages and to place them in a phylogenetic context in the world fauna.

Males, females, and larvae are available for all 6 North American species; we have studied also males of 10 , females of 6 , and larvae of 3 species from Asia. Iwata (1928) described as new 2 species from Japan on the basis of larvae and cases. Adding to this base the published descriptions of the other Asian species, we have made limited comparisons of the known world fauna. Characters of the male genitalia indicate that the 6 North American species form a monophyletic group, and that this group can be subdivided further into two subgroups of 3 species each based on adult and larval characters. Insufficient information is available to permit an adequate phylogenetic analysis of the relationships among the Asian species.

\section{Materials and Methods}

Associated adult and larval material in the Royal Ontario Museum forms the basis of this study. Specimens from other collections, including types, have been widely used; source and deposition of all specimens examined are noted at the end of this section. Distribution maps include all peripheral localities known to us, but only representative localities are plotted in the central part of the ranges of more common species; thus, not all records listed appear on the maps.

Identification of adult males of the Nearctic species can be accomplished without reference 10 genitalia, by the presence of eversible lobes on the second segment of the maxillary palpi of two species and on the dorsum of the head of one species, but these characters may be difficult to 
detect in a retracted condition. Clearing the head or the genitalia in $\mathrm{KOH}$ solution will confirm identification. Females are usually identifiable only by examination of cleared genitalia. Characters used in larval identification rely heavily on the standardized larval chaetotaxy developed by Williams and Wiggins (1981), and work most reliably with instar $\mathrm{V}$ larvae, although earlier instars can be identified in some species. Counts of notal setae were made at $\times 80$ magnification and included all setae. To avoid obscuring other details of the illustrations, not all setae are shown in the figures. Colour patterns are helpful in larval identification, but should not be relied upon wholly because of the variability within species. No pupal characters were found to be diagnostic at the species level, but pupae can be identified by reference to the larval exuviae which remain in the case at pupation. The criteria of Wiggins (1977) were used for the distinctions made between immature stages listed in the Material Examined sections; these stages are indicated by the following abbreviations: L-larva; PP-prepupa; P-pupa; MMTmetamorphotype.

\section{Locations of Specimens Examined}

ANsP Academy of Natural Sciences, Philadelphia, Pennsylvania.

CLEM Insect Museum, Department of Entomology and Zoology, Clemson University, Clemson, South Carolina, per J. C. Morse.

CNC Canadian National Collection, Ottawa, Ontario, per F. Schmid.

CU Cornell University, Department of Entomology, Ithaca, New York, per Q. D. Wheeler.

DGD D. G. Denning, Moraga, California.

GAS G. A. Schuster, Department of Biological Sciences, Eastern Kentucky University, Richmond.

INHS Illinois Natural History Survey, Natural Resources Building, Urbana, per J. D. Unzicker.

ICH J. C. Hodges, Roswell, Georgia.

KSBS Kansas State Biological Survey, Lawrence.

LB L. Botoşăneanu, Institut voor Taxonomische Zoologie, Universiteit van Amsterdam.
MCZ Museum of Comparative Zoology, Harvard University, Cambridge, Massachusetts.

OSF O. S. Flint, Jr, Department of Entomology, National Museum of Natural History, Smithsonian Institution, Washington, D.C.

ROM Department of Entomology, Royal Ontario Museum, Toronto.

UL Université Laval, Provancher Collection, SainteFoy, Québec, per J.-M. Perron.

USNM United States National Museum of Natural History, Smithsonian Institution, Washington, D.C., per O. S. Flint, Jr.

UT University of Tennessee, Department of Zoology, Knoxville, per D. A. Etnier.

VPI Virginia Polytechnic Institute and State University, Blacksburg, per J. R. Voshell, Jr.

ZIM Zoologisches Institut und Museum, Hamburg, per H. Strumpel. 


\section{Genus Psilotreta Banks}

Psilotreta Banks, 1899:213, type species $P$. frontalis Banks, by monotypy.

Astoplectron Banks, 1914:264-265, type species Heteroplectron borealis Provancher, by original designation. Synonymy by Betten, 1934:240.

The adult is distinguished by having the separation of $R_{2}$ and $R_{3}$ markedly basad of the separation of $R_{4}$ and $R_{5}$ in both wings (Figs. 4-7, 20, 52). The larva is distinguished by a pointed anterolateral corner of the pronotum, and genae contiguous along most of the median ventral ecdysial line of the head.

\section{ADULT}

Medium sized (forewing 6-17 mm in length), black, grey, reddish or yellowish brown. Head (Figs. 1-3, 50) short and broad; antennae longer than forewing, slightly longer in male than in female, scape subequal to length of head, first two flagellar segments fused, with or without a suture line; eyes glabrous, large, slightly larger in male. Setal warts with long hairlike setae and/or scales; frons with anterolateral setal wart along anterior margin of eye below antennal socket, with or without a large median wart or pair of warts on frontoclypeus; vertex with anteromesal warts absent or situated on raised prominences separated by narrow, deep fissure extending below base of antennal sockets; narrow transverse anterior warts posterad of antennae present or absent, larger transverse to oval posterior warts near posterior margin of head, and elongate, narrow posterolateral warts extending ventrally along posterior margin of eye, or anterior and posterior warts apparently combined into one large wart (Fig. 3), or posterior

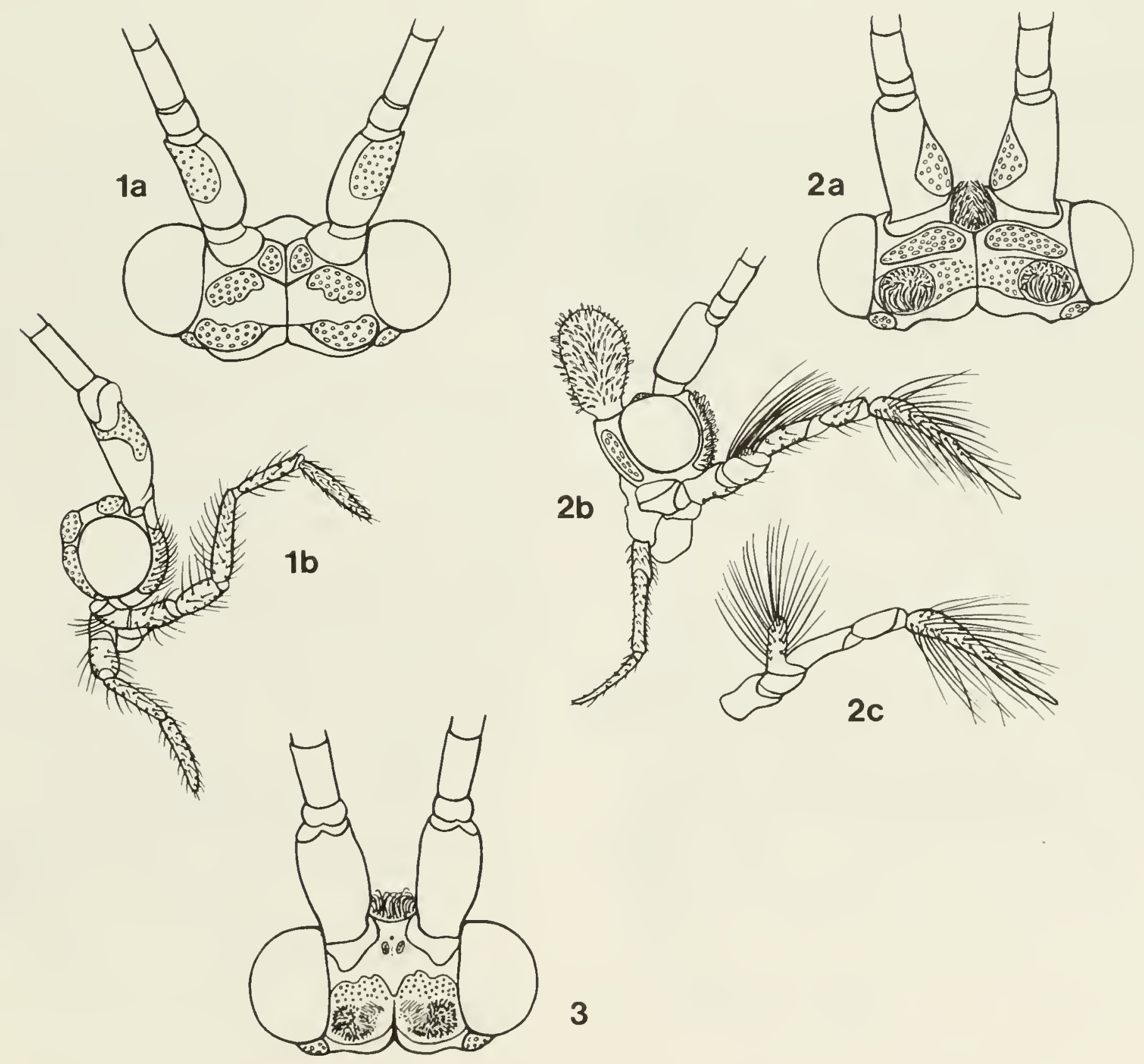

Figs. 1-3. Psilotreta spp., adults. I. P. indecisa: $a, b$, head of $\delta$-dorsal, lateral. 2. P. fromtalis: $a, b$, head of $\delta$-dorsal, lateral; $c$, maxillary palpi of $\delta$, lobe everted. 3. P. amera, head of $\delta$-dorsal. 
pair replaced by large eversible scale-covered lobes (Fig. 2). In some species vertex of male excavated (Fig. 50). Maxillary palpi five-segmented in both sexes, long, with apex of third segment reaching past base of scape, very setose, sometimes with scales intermingled, and unmodified or with dorsal eversible lobe on second segment of male of some species (Fig. 2c). Labial palpi with first segment short, second and third long, subequal.

Tibial spurs 2, 4, 4. Wings (Figs. 4-7) elongate, forewings longer and narrower than hindwings, densely hairy, with or without scattered scales; discal cell usually present, but absent in some species; $\mathrm{Cu}_{1 \mathrm{a}}$ and $\mathrm{Cu}_{1 \mathrm{~b}}$ separate in forewings of both sexes and in hindwings of female, but undivided in hindwings of male; male with $\mathrm{Cu}_{1 \mathrm{a}}$ fused with $\mathrm{M}_{3+4}$ and stems of $\mathrm{Cu}_{1}$ and $\mathrm{M}$ fused in forewings; $\mathrm{M}_{1+2}$ divided in both wings of female in some species; stigmatic region whitish opaque.

Male genitalia. Segment VII of some species with a small eversible lobe at posterior corner of pleuron, usually withdrawn and indistinct, or with narrow dorsoventral invagination near posterior margin. Segment VIII unmodified. Segment IX with anterolateral margin invaginated into VIII, heavily sclerotized, much broader and thicker below midline, with a few long setae posterolaterally and ventromesally, dorsum subtriangular or produced into a long slender process extending posteriorly beyond rest of segment, often finely granular, with sharp steep sides, or produced laterally into a small overhanging ledge, and with lateral borders fused with body of segment $\mathrm{X}$ (these segments together forming an elongate "phallus guide,' open ventrally, and into which the phallus normally is retracted); anal aperture in membranous roof of phallus guide; inferior appendages two segmented - basal segment elongate, cylindrical, slightly tapered, either somewhat curved in ventral aspect and with or without a low median lobe basally, or thick and quadrate in lateral aspect (Schmid, 1959, pl. 4, fig. 8; Botoşăneanu, 1970, pls. 3638 ), and apical segment short, rounded, tapered or foot shaped (Mosely, 1942, fig. 8; Hwang, 1957, figs. 94, 95),
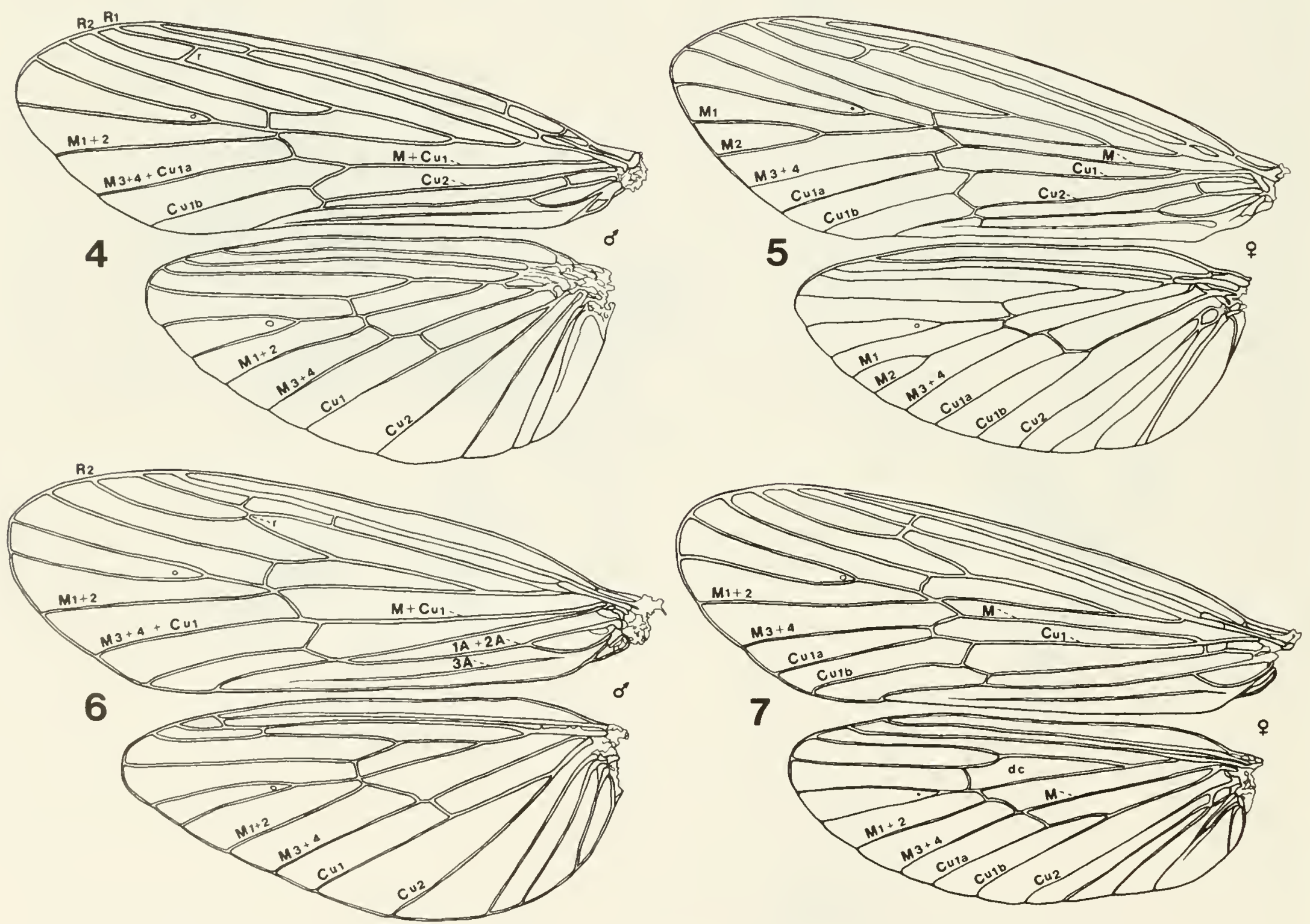

Figs. 4-7. Wings of Psilotreta spp. 4. P. indecisa O. 5. P. indecisa 9. 6. P. rufa O. 7. P. rufa 9. 
and with from two to many stout black teeth apically - both segments with numerous long setae. Segment $\mathrm{X}$ consisting of several pieces and processes variously developed in different species; pair of rounded or elongate setal warts at base; in dorsal aspect a bifid or entire, narrow median process extending posteriorly, with a few setae apically; thin, sclerotized lateral processes arising from median process, each fused partially or completely along its dorsal edge to the median process; lateral processes large, rounded or pointed, and with or without anterior projections or processes, or very narrow and sinuous, or absent; ventrally from the lateral processes arises a pair of stout, curved sclerotized intermediate appendages (sensu Schmid, 1980), which may be short and inconspicuous (Fig. 5la) or, more often, large and recurved into a ramshorn shape (Fig. 11a), and occasionally bifid; preanal appendages either large and thin, somewhat foliaceous in lateral aspect, widest just beyond base, and pointed apically, or small and subcircular with long setae.

Phallus with phallotheca sclerotized, long and cylindrical, curved, with one or both ends flared ventrally; endotheca short and membranous; parameres absent in North American species (Fig. 1ld,e), present in Asian species, varying from long, slender, acute rods (Fig. 48d,e) to broad, flat, bladelike structures (Fig. 55d,e); endotheca of one species possessing a pair of small endothecal processes arising dorsad of parameres (Fig. 5ld,e); aedeagus membranous with three or more eversible lobes, some species having a ventral sclerite (Fig. 11d,e); phallotremal sclerite long and delicate, not prominent.

Female genitalia (Figs. 12, 47). Sternum VIII rectangular in ventral aspect, with a row of fine setae along posterior edge. Sternum IX with conspicuous sclerotized triangular or hemispherical posterior portion, divided longitudinally in some species; anterior portion rectangular and usually clearly distinct from the posterior portion by less sclerotization, less pigmentation, or different texture; tergum IX fused laterally with anterior portion of sternum IX, extruded posteriorly on each side as broad, rounded lobes meeting in a posteromedian cleft, and flexibly joined to posterior edge of sternum IX; apex of posterior portion of sternum IX delineates narrow vaginal aperture. Tergum $\mathrm{X}$ fused indistinguishably with tergum IX dorsally and bearing two large, low, oval setal warts (appendages of Schmid, 1980). Vaginal chamber elongate and extending into segment VIII, with prominent posterior and anterior vaginal sclerites (sensu Unzicker, 1968), the posterior vaginal sclerites heavily sclerotized in some species and less sclerotized to membranous in others, and the anterior vaginal sclerites broadly rectangular or oval and connected to the posterior by complexly folded sclerites.
LARVA (Figs. 8, 9)

Head without secondary setae, sclerites smooth and shiny, or textured with pebbling or fissures; a prominent dorsal ridge extending posteriorly from anterolateral corner of head capsule at dorsal mandibular articulation, along inner margin of eye to about two-thirds length of head; antenna short and inconspicuous, situated near dorsal mandibular articulation, bearing an apical papilla and seta; ventral apotome short, genae contiguous for much of their length; two heavily sclerotized plates situated on maxillolabial complex at anterior border of ventral apotome between cardines (Fig. 8c). Mandibles (Fig. 8d) very broad and scoop shaped, each with apex having one or two points, dorsal margin thin, bladelike, and extending farther mesally than ventral margin; mandibles asymmetrical, with left mandible having less pronounced apex and broader dorsal mesal margin; both mandibles lacking mesal brush of setae.

Thorax and legs with numerous secondary setae. Anterolateral corner of pronotum produced into point that ranges from long and acute (Fig. 25) to short or absent (Fig. 30). Mesonotum with two plates, each with a low, sharply defined ridge along posterior margin extending from midline laterally to posteroventral corner of sclerite and ending there abruptly at a narrow excision of the posterior margin (Fig. 25) or at a light spot (weakness) in the same area (Fig. 30). Metanotum with two transverse sclerites-anterior sclerite broadly rectangular, much larger, and with many more secondary setae than the narrow posterior sclerite, which has essentially a single row of setae-and an oval lateral sclerite with numerous setae on each side of metanotum above pleurites; metanotal pleurites with primary setae 10 and 11 long and prominent, setae 19 and 20 fine and inconspicuous, secondary setae absent. Each thoracic segment with sternum sclerotized, the sternal sclerite extending completely across segment, articulating behind coxae with posterior corner of notum, and extending forwards to near anterior margin of segment; prosternite of one solid piece, mesosternites and metasternites subdivided into four plates that are readily discernible only in very dark specimens. Trochanters composed of four sclerites (Fig. 8e,f), protrochanters and mesotrochanters with secondary setae (trochanteral brush).

Abdomen with segment I lacking gills and secondary setae, a pale oval sclerite bearing paired setae 12, and a median dorsal and 2 lateral spacing humps, the lateral humps with setae 7 and 8 posteriorly and with a patch of fish-scale-like sculpturing anteriorly (Fig. 9), each scale consisting of a low crescentic mound armed with a row of approximately 30 spines. Branched gills present dorsally on segments II to VI, VII, or VIII, ventrally on II to VII or VIII, and sometimes laterally on II to III. Lateral fringe 


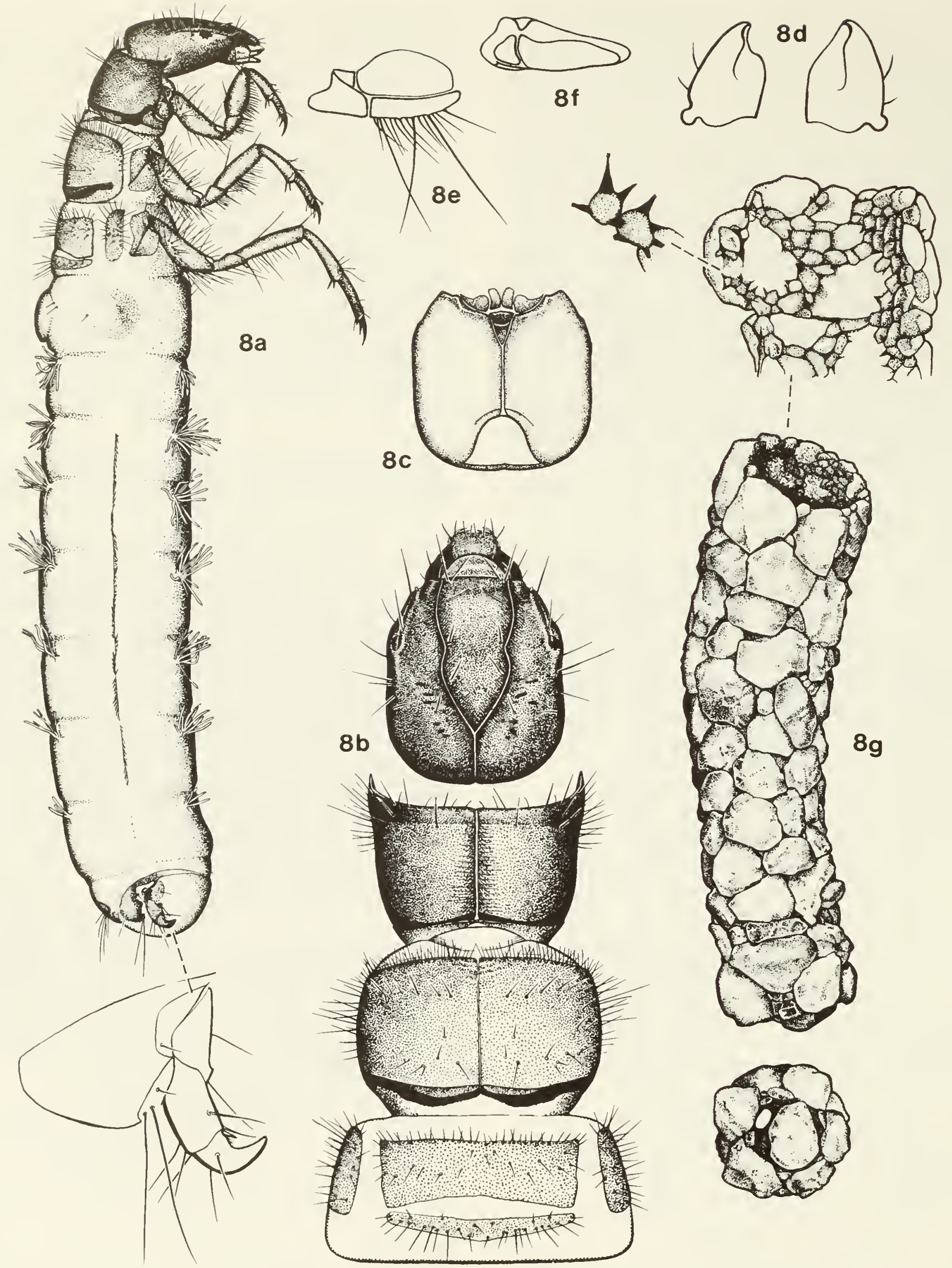

FIG. 8. Larva of Psilotreta rufa: $a$, habitus-lateral, with detail of anal proleg; $b$, head and thorax-dorsal; $c$, head-ventral; $d$, mandibles-ventral; $e, f$, right mesotrochanter-posterior, dorsal; $g$, larval case-lateral with details of construction and posterior end. 

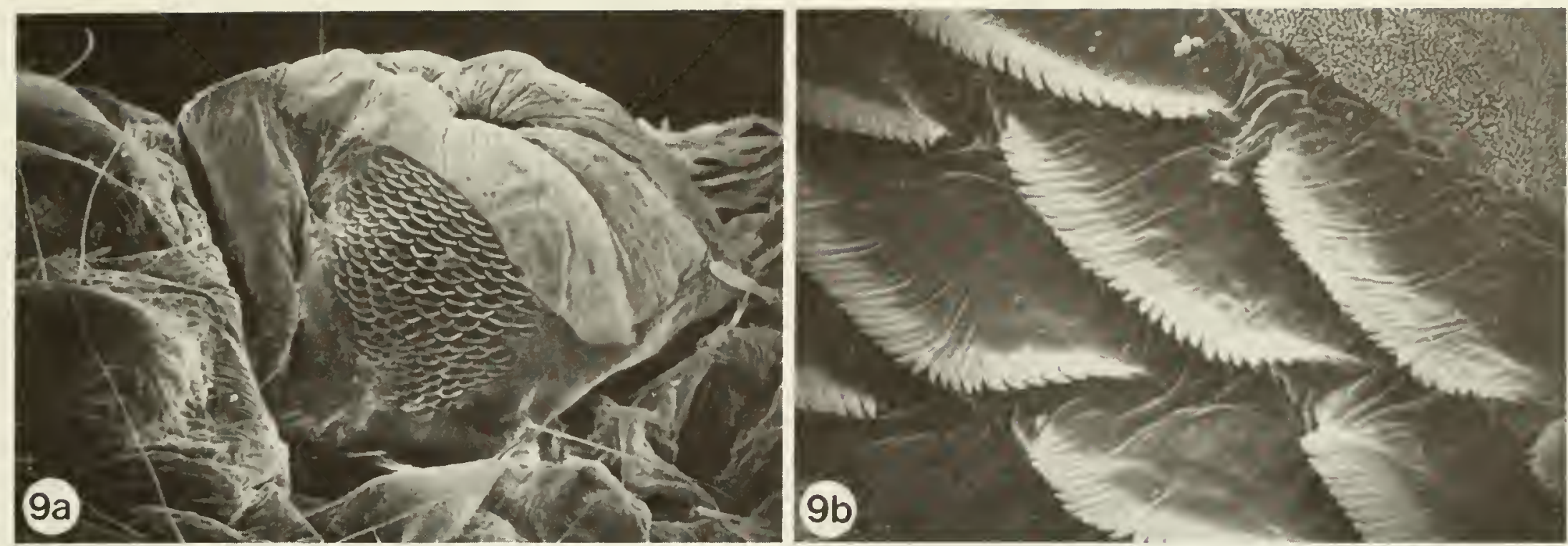

Fig. 9. Spacing hump of first abdominal segment of Psilotreta labida, dorsal aspect, right side: $a, \times 50 ; b$, $\times 940$.
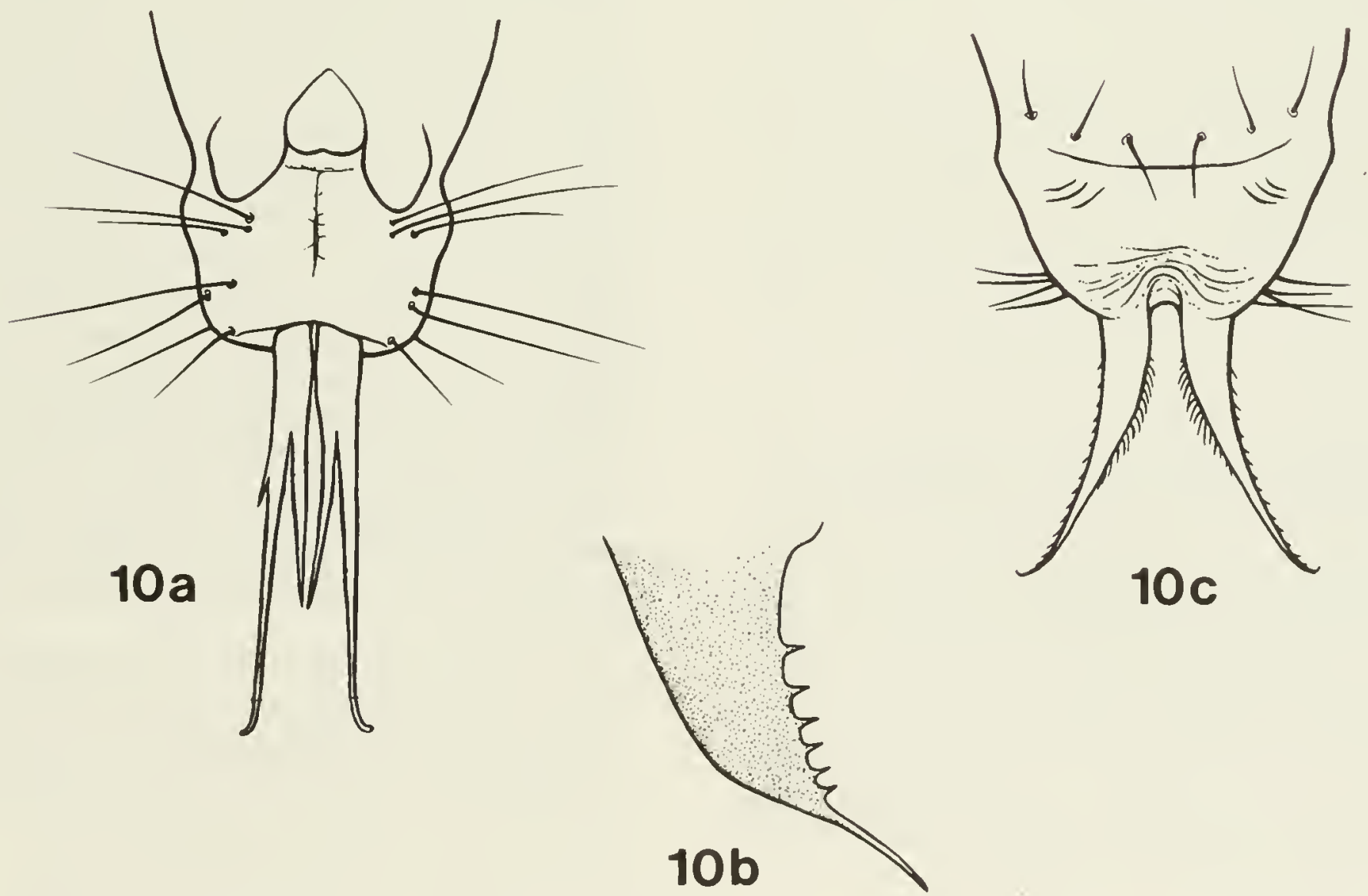

Fig. 10. Pupal structures of Psilotreta spp. $a$, Asian species, anal processes-dorsal; $b$, Asian species, mandible-frontal; $c$, North American species $(P$. indecisa), anal processes-dorsal. 
present on III to VII. Lateral tubercles present on VIII, variable in number. Dorsal sclerite of segment IX with 4 pairs of setae $(2,3,1,5$ in dorsal to lateral sequence; Williams, 1983), setae 2 and 5 large and dark, setae 3 and 1 fine and pale; seta 7 laterad of dorsal sclerite. Anal proleg with lateral sclerite large and rounded dorsally, with a prominent ventral extension; seta l present dorsally, seta 6 on membrane between lateral sclerite and ventral sole plate, setae 2, 5, and 7 on small dorsal plate, and seta 12 on ventral sole plate; no secondary setae or spines on lateral plate, dorsal plate, or ventral sole plate; anal claw slender in lateral aspect with apex broadly rounded, with 8 primary setae present and usually a brush of small secondary setae present ventrally just beyond ventral sulcus, and with 2 to 3 accessory hooks present dorsomesally.

\section{CASE (Fig. 8g)}

Cylindrical, curved, and usually tapered, although cases of mature larvae of some species have little or no taper; made of coarse sand grains closely fitted, and on the inside, of smaller sand grains filling interstices between the larger grains and firmly attached with silken bracebands between adjacent rock pieces (Fig. 8g, detail), resulting in a remarkably sturdy case resistant to crushing. Posterior end of case with (usually) a single sand grain attached over opening and small spaces around edges allowing passage of water.

\section{PUPA (Fig. 10)}

Reference to the Indian pupa in the following description is to specimens of one undetermined species from India.

Mandibles (Fig. 10b; Wiggins, 1978, fig. 14.84) terminating in a long, curved, whiplike style, the apex of which may be hooked; mesal edge of both mandibles with 9 to 10 small teeth in Nearctic species and in $P$. locumtenens Botoşăneanu and with 4 to 7 larger pointed teeth in the Indian species (Fig. 10b). Head with vertex lacking setae in Nearctic species but bearing 2 pairs of setae in $P$. locumtenens and in the Indian pupa; Nearctic species with eye bearing a seta posteriorly, $P$. locumtenens and the Indian pupa lacking ocular seta; antennal scape with a basolateral tuft of setae, the Indian pupa also having a dorsal tuft. Pronotum bearing 2 to several setae dorsally on each side. Mesonotum bearing 5 to 8 setae anterolaterally and 2 to 6 setae posteriorly between wing base and mesoscutellum on each side in Nearctic species and in $P$. locumtenens, these areas bearing 20 to 27 setae and 5 to 7 setae, respectively, in Indian pupa. Metanotum with an anterolateral and a posterolateral tuft of setae on each side.

Abdomen (Wiggins, 1978, fig. 14.85) with paired dorsal hook-plates anteriorly on segments III to VII, each having a single hook, and posteriorly on segment $\mathrm{V}$, each having two hooks, hooks raised and projecting posteriorly from anterior plates and anteriorly from posterior plates, with apex of each hook blunt in dorsal aspect. Branched gills distributed on segments as in larvae. Lateral fringe arising on posterior corner of segment VI and extending posteriorly along segment VII to end of segment VIII, the filaments fine and silky, long on VI, short anteriorly on VII and becoming longer posteriorly, very long on VIII. Antennae of most species very long and extending ventrally to segment VIII, coiling around anal processes up to two complete turns; antennae of some species entangled in the long lateral fringe of segment VIII. Anal processes undivided in Nearctic species (Fig. 10c) and in P. locumtenens, approximately $\times 10$ longer than wide at midlength, tapering to a point and curved laterally at tips, dorsoventrally flattened and bearing numerous small spines and setae along lateral margins; in Indian pupa (Fig. 10a) anal processes bifid near midlength, with mesal branch short, straight, and bearing a few spines along mesal margin, and with lateral branch longer, slightly curved laterally at tip, and bearing small spines and setae along lateral margin.

Pupal cases closed at each end by a single capstone but with a small peripheral space for water to circulate through case. Pupal cases are usually attached to a solid substrate, and in some species large aggregations of pupae are found attached in layers to the undersides of rocks. 


\section{NORTH AMERICAN PSILOTRETA}

The six North American species of Psilotreta form a natural group phylogenetically (see Phylogenetic and Biogeographic Considerations), as well as geographically. All six species are restricted to small springs, creeks, and rivers of the eastern forests.

\section{Key to Adults of North American Species}

Genitalia with elongate paired appendages

(Fig. 11). Males .................

' Genitalia lacking elongate paired appendages (Fig. 12). Females................ 7

2(1) Forewing with $\mathrm{R}_{2}$ straight or with a slight kink at junction of crossvein $r$ (Fig. 4); median dorsal process of segment $X$ reduced, membranous, and fused throughout length to lateral processes (Figs. 11, 13, 15), indecisa subgroup ............................

Forewing with distinct kink in $\mathrm{R}_{2}$ at junction of crossvein $\mathrm{r}$ (Fig. 6); median dorsal process of segment $\mathrm{X}$ prominent, elongate, and largely free from lateral processes (Figs. 17, 19, 22). rufa subgroup .................5

3(2) Maxillary palp with a membranous eversible dorsal lobe on second segment, set with brush of long silky setae; terminal segment membranous, flexible, and subequal to combined length of preceding segments (Fig. 2b,c) .... ........... Maxillary palp unmodified: terminal segment not membranous and flexible, not more than 2 $\times$ length of preceding segment (Fig. Ib) $\ldots$. ..................... indecisa, p. 11

4(3) Head dorsally with a pair of large eversible lobes (Fig. 2b), appearing as scale-covered warts when retracted (Fig. 2a); segment IX with pair of long, thin, pointed styles arising beneath preanal appendages and extending posteriorly beneath segment X (Fig. 13a); inferior appendages with terminal segment bearing two to six black teeth (Fig. 13c)....... frontalis, p. 13 4' Head lacking dorsal eversible lobes (as in Fig. 1); segment IX without styles (Fig. 15a); inferior appendages with second segment bearing three to six black teeth, one (rarely two) of which is much longer than the others (Fig. 15c) labida, p. 18 $5\left(2^{\prime}\right) \quad$ Head with anterior and posterior warts distinct (as in Fig. la); intermediate appendages C-shaped, pointed posterodorsally: lateral processes broad and rounded, each with short or long projection ventrally (Figs. 17a, 19a) ..6 Head with one pair of large warts dorsally occupying most of vertex, covered with black scales laterally and golden scales mesally (Fig. 3 ); intermediate appendages comma shaped, directed ventrally; lateral processes of segment $X$ long, thin, and sinuate, each with apex acute and directed posteroventrally (Fig. 22a)...... .....................amera, p. 25

6(5) Lateral processes of segment $X$ broad and rounded, often with a short ventral projection (Fig. 17a); dark reddish brown species ...... rufa, p. 21

6' Lateral processes of segment $X$ rounded apically, each with a long, narrow ventral projection (Fig. 19a); light grayish brown species ...................rossi, p. 23

$7\left(\mathrm{I}^{\prime}\right) \quad$ Forewing with $\mathrm{R}_{2}$ straight or with a slight bend at attachment of crossvein $\mathrm{r}$ (Fig. 5); $\mathrm{M}$ threebranched in both wings...........8

$7^{\prime} \quad$ Forewing with distinct kink in $\mathrm{R}_{2}$ at junction of crossvein $r$ (Fig. 7); M two-branched in both wings ................. 10

8(7) Sternum IX with anterior portion lightly sclerotized (apIXs, Fig. 12c), or with scattered flecks of sclerotization resulting in a granular or reticulate appearance (apIXs, Fig. 14c); posterior vaginal sclerites lightly sclerotized (Fig.

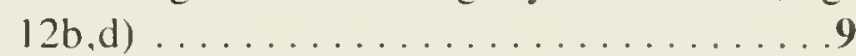

$8^{\prime} \quad$ Sternum IX with anterior portion heavily sclerotized (apIXs, Fig. 16c); posterior vaginal sclerites heavily sclerotized (Fig. 16b,d)

labida, p. 18

9(8) Sternum IX with anterior portion lacking granular or reticulate appearance (aplXs, Fig. 12c): posterior vaginal sclerites broad in ventral aspect (pvs, Fig. 12d); frontoclypeus with 5 to 10 setae............... indecisa, p. 11

9' Sternum IX with anterior portion having granular or reticulate pattern (aplXs, Fig. 14c): posterior vaginal sclerites narrow (pvs, Fig. 14d); frontoclypeus with 20 to 30 setise.

frontalis, p. 13 
10(7') Hindwing with discal cell open (Fig. 20); light grayish brown species .........rossi, p. 23

10' Hindwing with discal cell closed (Fig. 7); dark reddish brown species...........11

11(10') Sternum IX with anterolateral corners deeply invaginated (inv., Fig. 23c), tergum IX with shallow indentation (ind., Fig. 23a); posterior vaginal sclerites in ventral aspect with medial edges nearly parallel (Fig. 23d) ........... ...................mera, p. 25

11' Sternum IX with anterolateral corners not invaginated and tergum IX lacking indentations (Fig. 18a,c); posterior vaginal sclerites in ventral aspect with medial edges widely separated anteriorly, converging posteriorly until they meet or nearly meet at vaginal aperture (Fig. 18d) .................. rufa, p. 21

\section{Key to Larvae of North American Species}

Mesofemur with ventral seta 3 arising in line with dorsal seta 1 or distad of it by no more than approximately the distance between ventral setae 4 and 5 (Fig. 24); head seta 17 subequal to or greater in thickness than seta 15 and more than one-half length of seta 15 (Fig. 25), generally dark brown; head black with whitish or yellowish markings forming distinctive patterns of broad dark or light longitudinal bands that are continued to thoracic nota (Figs. 3234) . . . . . . . . . . . . . . . . . . . 2 Mesofemur with ventral seta 3 arising distad of dorsal seta I by more than the distance between ventral setae 4 and 5 (Fig. 28); head seta 17 much thinner than seta 15 and no longer than one-half length of seta 15 (Fig. 29), colourless to light brown; head uniformly reddish brown or with pale areas laterally; thoracic nota uniformly reddish brown to pale yellowish, or with indistinct darker markings marginally (Figs. 35-37) .....................4

2(1) Anterolateral corner of pronotum long and acute (Figs. 25, 27); anteroventral angle of mesepisternum generally pointed (Figs. 25, 27); head in dorsal aspect with broad black stripe widest at anterior margin of head capsule and either narrowing gradually posteriorly (Fig. 32) or of more or less uniform width throughout or widening posteriorly (Fig. 34); frontoclypeus uniformly black. . . . . . . . . . . . 3 2' Anterolateral corner of pronotum short (Fig. 26); anteroventral angle of mesepisternum short (Fig. 26); head in dorsal aspect with broad black stripe constricted anterior to eyes and narrowing gradually posteriorly; frontoclypeus black except for light areas at the anterolateral corners (Fig. 33) ......... frontalis, p. 13

3(2) Mesonotum with posterior margin dark medially, fading laterally and becoming obscure before reaching posterior inflection (Figs. 25 , 32): colour pattern as in Fig. $32 \ldots \ldots \ldots \ldots$ Mesonotum with posterior margin black at least to posterior inflection (Figs. 27, 34); colour pattern as in Fig. 34 ......... labida, p. 18

4(1') Head seta 17 much less than one-half length of seta 15 (Figs. 30, 36) .......... rossi, p. 23

$4^{\prime} \quad$ Head seta 17 about one-half length of seta 15 (Fig. 29a)...................... . .

$\mathbf{5}\left(4^{\prime}\right) \quad$ Dorsum of head appearing domed between carinae (Fig. 31b); head as long as wide (Fig. 37)

$5^{\prime} \quad$ Dorsum of head relatively flat between carinae Fig. 29b); head longer than wide (Fig. 35) ... .rufa, p. 21 


\section{Psilotreta indecisa Group}

This group, characterized by the absence of parameres in the male, comprises the six North American species and is divided into the indecisa and rufa subgroups. The distinguishing characteristics in the indecisa subgroup- $P$. indecisa (Walker), $P$. frontalis Banks, and $P$. labida Ross-are as follows: $R_{2}$ is straight or has only a slight kink at the junction of crossvein $r$ in the forewings of both sexes (Figs. 4, 5); $\mathrm{M}$ is three-branched in both wings of the female (Fig. 5); the male has the median dorsal process of segment $\mathrm{X}$ reduced, membranous, and fused throughout its length to the lateral processes (Fig. 11); the larva has head seta 17 dark brown, thicker than seta 15 , and longer than one-half the length of seta 15 (Fig. 25), and has the mesofemur with ventral seta 3 more or less in line with dorsal seta 1 , or distad of it by approximately the distance between ventral setae 4 and 5 (Fig. 24). The rufa subgroup- $P$. rufa (Hagen), $P$. rossi Wallace, and $P$. amera (Ross) - is distinguished as follows: $R_{2}$ is distinctly kinked at the junction of crossvein $r$ in the forewings of both sexes (Figs. 6,7); $\mathrm{M}$ is two-branched in both wings of the female (Fig. 7); the median dorsal process of segment $X$ in the male is a prominent, elongate process largely free of the lateral processes beyond its base (Fig. 17); the larva has head seta 17 colourless to clear brown, much thinner than seta 15 , and no longer than one-half the length of seta 15 (Fig. 29), and has the mesofemur with ventral seta 3 situated distad of dorsal seta 1 by a distance clearly greater than that between ventral setae 4 and 5 (Fig. 28).

\section{Psilotreta indecisa (Walker)}

Goera indecisa Walker, 1852:95. Holotype ơ (British Museum [Natural History]), St Martin's Falls, Albany River, Hudson Bay, Ontario.

Leptocerus indecisus-Hagen, 1861:279.

Heteroplectron borealis Provancher, 1877:263. Holotype q (UL), Québec. NEW SYNONYMY.

Heteroplectron indecisus-Betten, 1934:237 (Calamoceratidae).

Heteroplectron indecisum-Milne, 1936:80.

Psilotreta indecisa-Betten and Mosely, 1940:46-49, fig. 22.

Psilotreta indecisa-Ross, 1944:286, fig. 956.

Psilotreta indecisa-Schmid, 1983:46-47, figs. 258, 262269, 283, map 21.

This species is readily distinguished from the others in the indecisa subgroup by the unmodified maxillary palpi of the male, as well as by details of the genitalia of both sexes as set out in the key. The larva is distinguished by the attenuated posterior dark ridge of the mesonotum, the acute anterolateral corner of the pronotum, and the colour pattern.

\section{ADULT}

Forewing 10-14 $\mathrm{mm}$ in length. Antennae dark brown basally, becoming paler apically, with numerous closely appressed, short brown setae; antennae long and slender, about $1.2 \times$ forewing length in female, $1.7 \times$ in male; scape (Fig. 1a) $4 \times$ longer than pedicel, first two flagellar segments fused and $2.5 \times$ length of pedicel. Maxillary palpi (Fig. Ib) identical in both sexes, unmodified, with many long erect setae on first three segments and shorter, recumbent setae on last two segments; labial palpi with long erect setae, first segment two-thirds length of second and third segments. Frontoclypeus convex, appearing slightly swollen ventrally, with a few (5-10) scattered setae. Thorax dark brown to blackish dorsally, lighter laterally and ventrally; legs light brown. Forewings brown with faint irrorations; hindwings lighter with numerous long, unmodified setae in anal area. Abdominal terga and sterna light to dark brown; pleura whitish.

Male genitalia (Fig. 11). Segment VII with pleural membranes forming distinct enlarged lobe posteriorly. Segment IX with apical segment of inferior appendages possessing five to nine short, black, mesally curved teeth; number of teeth often different on right and left sides of same individual. Segment $X$ with lateral processes projecting posteriorly nearly as far as tips of inferior appendages; lateral processes broad in lateral aspect (Fig. 11a), subparallel in basal half, tapering to sharp, laterally curved point apically, and with actual shape differing considerably between specimens.

Phallus (Fig. 11d,e) long, with phallotheca heavily sclerotized, cylindrical and narrow basally, and having ventral lip enlarged apically; endotheca short; aedeagus with large dark phallotremal sclerite and indistinct ventral sclerite, and with four membranous apical lobes when fully everted.

Female genitalia (Fig. 12). Genitalia typical for genus. Anterior portion of sternum IX lightly sclerotized; posterior vaginal sclerites broad and lightly sclerotized.

\section{LARVA (Figs. 24, 25, 32)}

Colour pattern with frontoclypeal apotome entirely black; parietals each with black stripe along frontoclypeal ecdysial lines, the two stripes meeting at coronal ecdysial line and continuing posteriorly to margin of head capsule. the whole appearing as broad, triangular black stripe, parietals vary from reddish brown to whitish dorsally. becoming black below eye, and fading to dark reddish brown along ventral ecdysial line and along posterior 

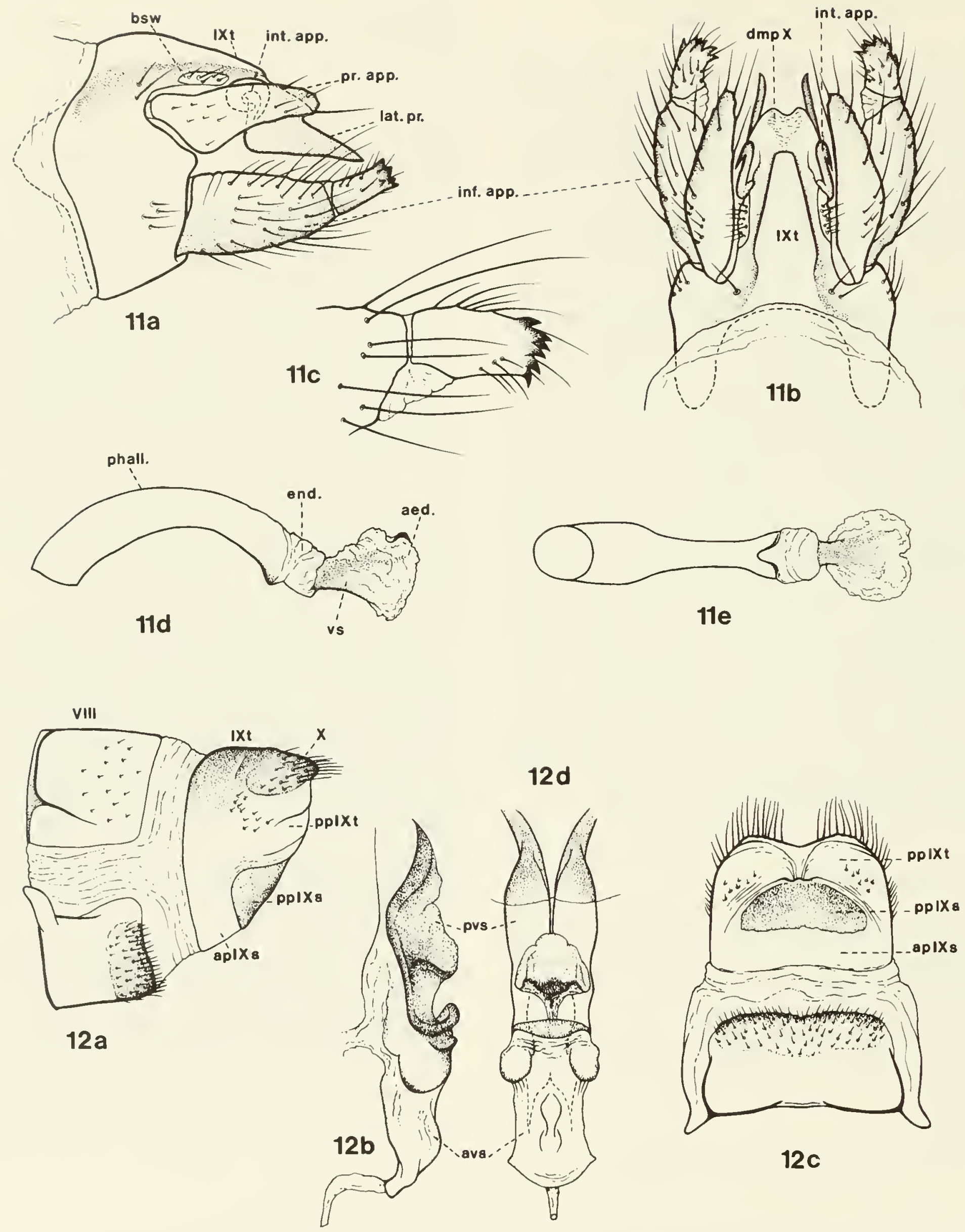

Figs. 11, 12. Psilotreta indecisa. 11, a,b, o genitalia-lateral, dorsal; $c$, apical segment of inferior appendage - ventral; $d, e$, phallus - lateral, ventral (aed.—aedeagus; bsw - basal setal wart; dmpX —median dorsal process of segment X; end.-endotheca; inf. app.-inferior appendage; int. app.--intermediate appendage; IXt—tergum segment IX; lat. pr.-lateral process of segment X; phall.—phallotheca; pr. app.preanal appendage; vs-ventral sclerite of aedeagus). $12 . a, c$, $q$ genitalia-lateral, ventral; $b, d$, vaginal apparatus-lateral, ventral (apIXs_anterior portion of sternum IX; avs-anterior vaginal sclerite; IXttergum segment IX; ppIXs - posterior portion of sternum IX; ppIXt-posterior portion of tergum IX; pvsposterior vaginal sclerite). 
margin of head capsule; pronotum black to dark reddish brown with pale spot posteromesally on each sclerite; mesonotal and metanotal sclerites progressively lighter posteriorly, so that posterior metanotal sclerite is light yellowish; pleural sclerites dark reddish brown to black, coxae and trochanters reddish brown with black dorsally, femora black dorsally and reddish brown ventrally, and tibiae and tarsi black.

Head (Fig. 32) longer than wide, narrowest anteriorly; seta 17 dark brown, thicker than seta 15 , subequal in thickness to seta 14 (Fig. 25). Pronotum with projection of anterolateral corner about $0.2-0.4 \times$ middorsal length of pronotum. Mesonotum with dark marking of posterior ridge not extending laterad to posterior inflection; mesepisternum with anteroventral projection prominent, long (Fig. 25). Metanotum (Fig. 32) with anterior sclerite bearing 32-47 setae, posterior bearing 17-23, each lateral bearing 29-38. Abdominal segment VIIl bearing 6-24 lateral tubercles on each side. Abdominal gills: dorsal-11 18-27, III 22-38, IV 15-20, V 12-17, VI 0-7, V11 0-5; ventral-11 12-23, I11 20-34, IV 14-15, V 19-20, VI 1718, VII 13-15. Larva up to $12 \mathrm{~mm}$ in length; head up to 1.1 $\mathrm{mm}$ in width across eyes. Larval case up to $14 \mathrm{~mm}$ in length.

\section{NOTES}

We have examined the type of Heteroplectron borealis Provancher. It is a female identical in all respects with $P$. indecisa females; accordingly we designate the name a junior subjective synonym of Psilotreta indecisa (Walker).

\section{HABITAT AND BIOLOGY}

According to Hilsenhoff (1981), P. indecisa lives 'in small, sand- and gravel-bottomed creeks, where larvae feed on algae in the sand.' Collection records of ROM field parties indicate that this species also occurs in moderatesized rivers with strong current, and in water temperatures of $14-23^{\circ} \mathrm{C}$.

\section{DISTRIBUTION (Fig. 38)}

The northernmost and westernmost of the Nearctic Psilotreta: New Brunswick, New Hampshire, Nova Scotia, Ohio, Ontario, Québec, Pennsylvania, Wisconsin.

\section{MATERIAL EXAMINED AND ADDITIONAL RECORDS}

NEW BRUNSWICK-Nipisquit R., 12.viii.1980, L (ROM). NEW HAMPSHIRE-Coos Co., Colebrook, 19.vi-20.vii (fide Morse and Blickle, 1953). NOVA SCOTIA-Baddeck Forks, 1.vii.1936, 1 ㅇ (ROM). OHIO_Portage Co., W. Branch, Mahoning R., v-vi (fide McElravy et al., 1977). ONTARIO-Algonquin Prov. Pk: str. crossing Hwy 60, $4.4 \mathrm{mi}$. e. Opeongo L. Rd, 11.v. 1972, L (ROM 720118); Madawaska R. crossing Hwy 60, 29-31.v.1972 (preserved 6.vii.1972), P (Rом
720203); same, 27-28.ix.1972, L (Rом 720244). Cochrane Dist.: Ft Albany, 52 $\mathrm{N}$, 29.vi.1942, 1 \& (ROM); Pitopiko R. between Longlac and Hearst on Rt. 11, 25.vi.1971 (emerged and preserved 27.vi-18.viii.1971), L P, 1 † 5 ९ (Rом 710472); St Martin's Falls, Albany R., holotype o (BMNH, not examined). Grey Co., North Spey R., Hwy 10 s. Rockford, 21.v.1976, o P (ROM). Hastings Co., Thurlow Twp, Latta, Moira R. below bridge, Conc. V1, 15.x.1968, L (ROM). Nipissing Dist., Samuel de Champlain Prov. Pk ca 9 mi. w. Mattawa, Pautois Cr. at Hwy 17, 22.v. 1977 (preserved 1.viii.1977), P (ROM 770036). Carleton Co., Richmond, Jock R., 20.v.1948, 3 o (ROM). Sudbury Dist., $34.2 \mathrm{mi}$. w. Timmins, Eastman Cr. crossing Hwy 101, 23.v. 1972 (preserved 3.viii. 1972), PP (вом 720181). Thunder Bay Dist.: Geraldton, Creelman's Cr., shallow rapids, 13.vi.1966, P (ROM); $13.6 \mathrm{mi}$. sw. Geraldton crossing Rt. 11, 22-23.vi. 1971, L P (ROM 710451 ); $11.1 \mathrm{mi}$. ne. Jellicoe, Sturgeon R. at Rt. 11, 22.vi.1971 (emerged and preserved 23.vi-26.vii. 1971), L P, 2 o 4 \& (ROM 710450); Kakabeka Falls Prov. Pk, Kaministikwia R., 19.vi.1971, L (ROM 710434). PENNSYLVANIA - Crawford Co.: Linesville Cr., 2.x.1965, L; same, 5.vi.1968, 2 oे 1 \%; same, 22.v.1971, 1 of 1 \%; same, 22.v.1973, 10 ơ; same, 22.v.1977, 10 o 5 ; same, 22.x.1977, L; all USNM. QUÉBEC-C.(henal?) Ste Catherine, 15.vi.1955, 7 o (ROM). Gatineau Co., Wakefield, 4.vi.1935, 1 o 4 \& (ROM). Île Ste Hélène, 5.vi.1965, P; same, 9.vi.1965, P; same, 10.vi.1965, P; same, 18.x.1965, L (ROM). (St Helen's Island) Montréal, St Lawrence R., L (fide Corbet et al., 1966). Lake St John Co., Mistassini, 10.vii.1954, 1 o 2 ㅇ (fide Harper et al., 1975). Mistassini Post, 28.vii. 1956, 1 ठ (ROM). Parc du Mont Tremblant: 16-17.vi, 2 oे (fide Roy and Harper, 1975); Rivière du Diable, 9.vi, adults (fide Robert, 1960). Rivière Nabisipi, 11.vii.1962, I ơ (fide Harper et al., 1975). Saguenay Co., 32 km e. Sept-Îles, Matamek R. nr Matamek Res. Stn, $50^{\circ} 17^{\prime} \mathrm{N} \times 5^{\circ} 57^{\prime} \mathrm{W}, 15,20$.vii.1974, L PP P, of $q$ (fide Williams and Williams, 1979). Sherbrooke Co., Sherbrooke, vi.1894, \& (MCZ). WISCONSIN-10,20.vi (fide Longridge and Hilsenhoff, 1973; Hilsenhoff, 1981). Florence Co.: Pine R., 10.vi, adults; same, 16.xi, L (fide Longridge and Hilsenhoff, 1972).

\section{Psilotreta frontalis Banks}

Psilotreta frontalis Banks, 1899:213. Holotype đ̇ (MCZ), Sea Cliff, New York.

Heteroplectron indecisum-Milne, 1936:80.

Heteroplectron gameta Ross, 1939:69, fig. 10.

Psilotreta frontalis-Betten and Mosely, 1940:49; as synonym of $P$. indecisa.

Psilotreta frontalis—Ross, 1944:286-287, figs. 86, 955A; $H$. gameta synonym of $P$. frontalis. 
Psilotreta hansoni?-Morse et al., 1980, table 9; status uncertain, probably synonym of $P$. frontalis.

Psilotreta sp.-Morse et al., 1980, table 9.

Psilotreta frontalis-Schmid, 1983:47, figs. 259, 274 277, map 12.

This species is readily distinguished by eversible lobes on the maxillary palpi and head of the male, and by details of the genitalia of both sexes as set out in the key. The larva can be distinguished by the short projections of the anterolateral corner of the pronotum and of the mesepisternum, the large number of setae on the metanotal sclerites, and the colour pattern.

\section{ADULT}

In general appearance similar to $P$. indecisa; maxillary palpi of female identical with $P$. indecisa, but maxillary palpi of male (Fig. 2b,c) with eversible gland dorsally on second segment and with numerous long silky setae forming brush when lobe is retracted; first, second, and fourth segments subequal and short, third segment subequal to first two combined, fifth subequal to first four combined and flexible, with dark appressed setae. Frontoclypeus of female identical in shape with those of $P$. indecisa and $P$. labida females, but with numerous (20-30) yellowish setae; male with frontoclypeus a little swollen and with thick patch of scales covering setal warts on either side next to eyes, these patches extending dorsally between antennae. Male with dorsum of head bearing two large, eversible, scale-covered lobes (Fig. 2a,b) that appear as large setal warts when retracted.

Male genitalia (Fig. 13). Abdominal segment VII with pleural membranes forming enlarged lobe posteriorly. Segment IX with long, thin, acute style projecting posteriorly from below insertion of preanal appendages, and with apical segment of inferior appendage having two to five black teeth. Segment $X$ similar in all respects to $P$. indecisa.

Female genitalia (Fig. 14). Anterior portion of sternum IX with granular or reticulate appearance (Fig. 14c); posterior vaginal sclerites narrow (Fig. 14d).

LARVA (Figs. 26, 33)

Coloration highly variable, most specimens as illustrated (Fig. 33), but some very dark with light areas reduced, and some very light with median dark stripe. A broad black stripe extending dorsally over head capsule, widest at level of eyes where it extends full width of head capsule between eyes, gradually narrowing posteriorly; parietals with lateral light areas extending to anterolateral corners of frontoclypeus in all but darkest specimens, and widening gradually posteriorly; postgenae and genae very dark, becom- ing lighter along midventral ecdysial line; pronotal and mesonotal sclerites with lateral and middorsal black stripes becoming narrower posteriorly as longitudinal light stripes become larger posteriorly; mesonotum with black marking of posterior ridge extending past inflection to ventral margin; metanotum with anterior and lateral sclerites brown, posterior sclerite yellow; legs with coxae light brown, each successive segment darker than the preceding, claws dark.

Pronotum with projection of anterolateral corner short (Fig. 26), about $0.2 \times$ middorsal length of tergite, and usually slightly upcurved. Mesepisternum with anteroventral corner short. Metanotum (Fig. 33) with anterior sclerite bearing 56-90 setae, posterior bearing 19-32, each lateral bearing 37-50. Abdominal segment VIIl bearing 4 13 lateral tubercles on each side. Abdominal gills: dorsalII 21-26, III 25-31, IV 17-23, V 12-16, VI 1-12, VII 0I0, VIII 0-9; lateral-II 0-5, III 0-8; ventral-II 15-23, III 21-31, IV 18-23, V 15-22, VI 15-22, VII 12-21, VIII $0-16$. Length of larva up to $14 \mathrm{~mm}$; width of head across eyes up to $1.4 \mathrm{~mm}$. Larval case up to $16 \mathrm{~mm}$ in length.

\section{NOTES}

Psilotreta frontalis was described in 1899 and $P$. labida in 1944; much confusion exists in the literature prior to 1944 concerning the identity of $P$. frontalis, and many of the earlier records should be referred to $P$. labida. Unfortunately, since the ranges of these two species are largely sympatric (Fig. 38), it is not always possible to ascertain which species an author actually dealt with, and in fact it is clear that some authors dealt with both. Lloyd (1921), Sibley (1926), and Betten (1934) all worked with material collected at McLean Bog, New York. We have examined specimens from the Cornell University collection used by these authors and have found both $P$. frontalis and $P$. labida represented but all specimens identified as $P$. frontalis. The description and illustration of larvae by Lloyd lack the details concerning structural features used here to distinguish these species, but the colour pattern of the larva he illustrated is much more like that of $P$. labida than that of $P$. frontalis. Sibley described only pupae, which cannot be distinguished at the species level. Illustrations of the male by Betten (1934, pl. 27, figs. 9, 10; pl. 28, figs. 7,8) are clearly of $P$. labida rather than $P$. frontalis; the apical segment of the inferior appendage has an obvious mesal spine much larger than the other spines, and the lateral aspect of segment IX shows no indication of the style found in $P$. frontalis. We conclude that these three authors dealt with a mixture of both species, but primariiy with $P$. labida, which Lloyd and Betten, at least, illustrated as $P$. frontalis.

Denning (1948) described Psilotreta hansoni on the basis of a single male from Massachusetts; $P$. hansoni differs from $P$. frontalis in lacking the style on segment IX. Our examination of the holotype of $P$. hansoni revealed 


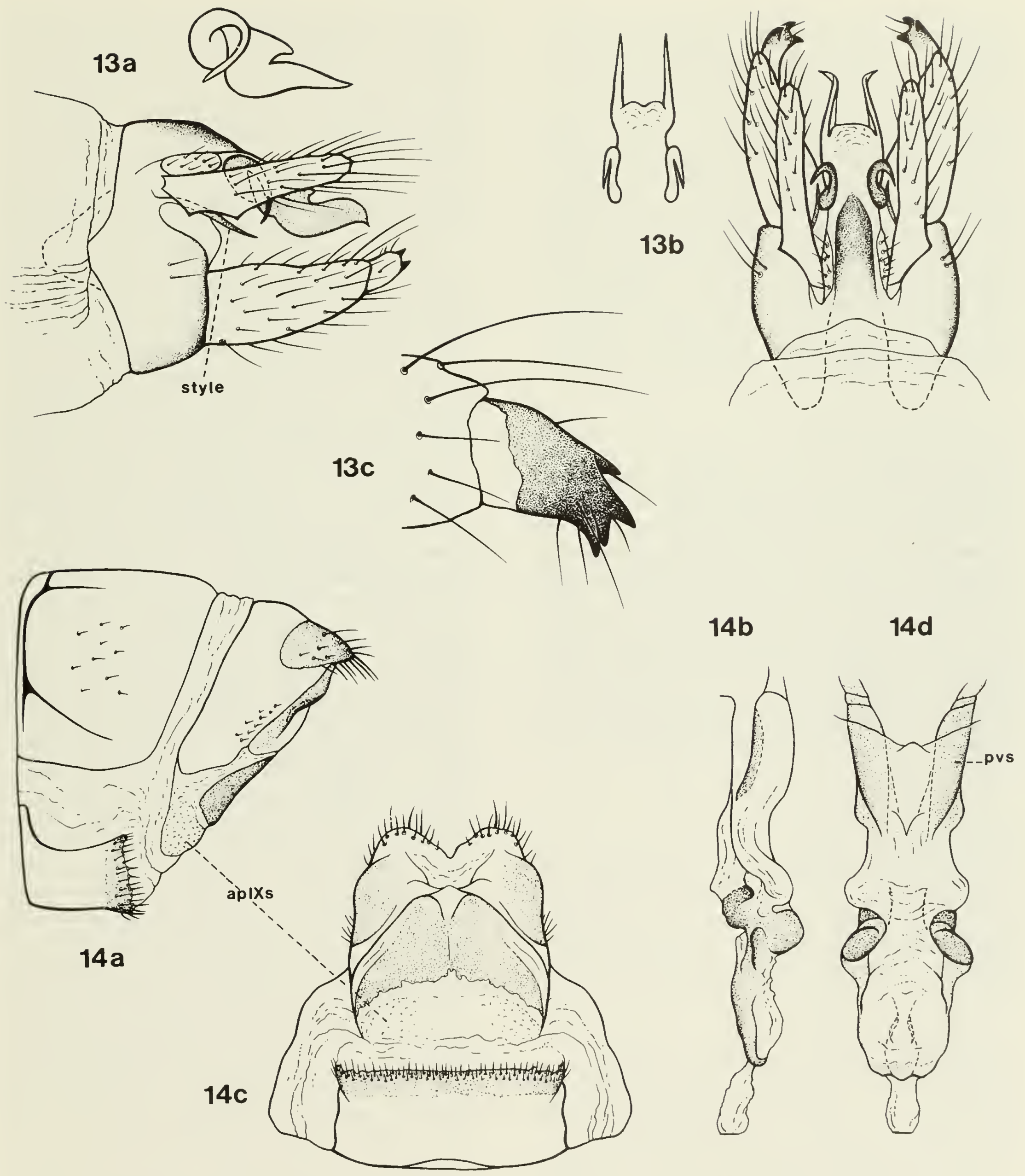

FIGS. 13, 14. Psilotreta frontalis. 13, $a, b, \delta$ genitalia-lateral, dorsal (with detail of variation in lateral processes of segment X); $c$, apical segment of inferior appendage-ventral. 14. a,c, $\&$ genitalia-lateral, ventral; $b, d$, vaginal apparatus-lateral, ventral (aplXs-anterior portion of sternum $1 \mathrm{X}$; pvs-posterior vaginal sclerite). 
that it has the eversible lobes on the second segment of the maxillary palpi and on the head as found in $P$.frontalis. In addition, we examined the two male specimens from South Carolina listed by Morse et al. (1980) as $P$. hansoni?; one is clearly a specimen of $P$. frontalis in which the style of segment IX is present; the other specimen lacks the style, but has eversible lobes on the head and maxillary palpi and in all other respects is indistinguishable from $P$. frontalis. No other specimens of $P$. frontalis that we examined lack the style. Although we cannot rule out the possibility that $P$. hansoni is a valid species differing from $P$. frontalis only by the absence of the style from segment IX, we believe that it is more likely that $P$. hansoni represents an unusual variant of $P$. frontalis; we therefore consider $P$. hansoni to be a species of doubtful validity, probably a synonym of $P$. frontalis.

\section{HABITAT AND BIOLOGY}

As discussed above, much of the published information on the biology of $P$. frontalis probably refers to $P$. labida, or to both species. Our observations indicate that $P$. frontalis is found primarily in well-shaded springs and spring-fed streams. Larvae can be observed crawling about in sandybottomed areas, and pupae are found attached to the undersurfaces of rocks in the stream or buried in the gravel up to $6 \mathrm{~cm}$ deep in marginal areas where no surface water is present. In South Carolina instar III larvae were observed (by C. R. Parker) feeding on Goniobasis snails; larvae attacked the snails through the shell opening. In one instance, two larvae were observed attacking the same snail.

\section{DISTRIBUTION (Fig. 38)}

$P$. frontalis reaches the easternmost extent of North America and extends farther south than any other Psilotreta: Connecticut, Delaware, Florida, Georgia, Massachusetts, New Brunswick, Newfoundland, New Hampshire, New Jersey, New York, North Carolina, Pennsylvania, Québec, South Carolina, Tennessee, Vermont, Virginia.

\section{MATERIAI, EXAMINED AND ADDITIONAL, RECORDS}

CONNECT1CUT-Hartford Co., Granby, McLean Wildlife Refuge, 7.vi.1962, 2 ơ (USNM). Litchfield Co., W. Woodbury, 21.iii.1952, L (OSF). DELAWARE-Kent Co., New Castle Co., Sussex Co. (fide Lake, 1984). FLORIDA-Gadsden Co., Bear Cr. 1 mi. n. Hwy 65C, 13.v.1970, 2 đ 1 (INHS). GEORGIA-Dawson Co., Amicalola Cr. at St. Pk, 17.v.1982, L, 1 o P 1 \& P (JCH). Greene Co., Cable Branch, 8.ii.1982, L (JCH). Lumpkin Co.: Jakes Branch, 8.ii.1982, L; same, 14.v.1982, 2 ơ $(\mathrm{JCH})$. Rabun Co.: Chattahoochee Nat. For. s. Tate City,
Tate Branch at Tate Br. Cpgrd, 16-17.v.1970, P (OSF); same, 17.v. 1970, P (ROM 700343). Union Co.: Vogel St. Pk, Wolf Cr., 7.iii. 1981, L (ClEM); same, 30-31.v.1980, 14 ơ (CLEM). MAINE-Isle au Haut Twp, off Stonington Hbr, Laundry Brook, 15.vi. 1981, L (ROM 811098). MASSACHUSETTS-1 $\delta$ (ROM). Franklin Co.: Colrain, sm. str. on Rt. 33, 796-V, 20.v.1972, L P (INHS); Leverett, Roaring Brook, of o (fide Neves, 1979); Sutherland, North Mountain Pond Rd, ơ o (fide Neves, 1979). Hampshire Co.: Amherst, 11.iv. 1953, L PP (OSF); nr Chesterfield, 6.vii. 1958, L (OSF); Cummington, 22.iii.1954, L; same, 30.iv. 1954, PP (OSF); Middlefield, Factory Brook, ơ oै (fide Neves, 1979); Westhampton, str. nr South and Stage Rds, 9.vi.1968, 2 ( (ROM). Suffolk Co., Jamaica Pl., 7.vi, 1 ( $q$ (OM). NEW BRUNSWICK - Charlotte Co., Waweig R. at Hwy 765, 45 $14^{\prime} \mathrm{N} \times 67^{\circ} 08^{\prime} \mathrm{W}$, 14.viii.1980, L (ROM 801048). NEWFOUNDLANDAvalon Peninsula: nr Bay Bulls, 21.vi. 1961, 1 \& 1 (fide Denning, in litt.); same, 27.vi.1961, 1 \& (USNM); Long Cove, 2.vi.1961, 1 o (fide Denning, in litt.); Loon Bay, 12.vii.1961, 1 o (fide Denning, in litt.). NEW HAMPSHIRE - Coos Co.: Base Rd nr Ammonoosuc R., sm. str., 9.vii.1977, L PP P, 1 đ (CLEM); Cutler R., Pinkham's Notch, 8-9.vii.1977, 1 ठ (CLEM); Fabyan, 3.viii. 1958, L (OSF); Jefferson Notch Rd, Abenaki Brook, 7-8.vii.1977, 3 o 1 ㅇ (CLEM). Grafton Co., Plymouth, Fox Inlet \#3, 25.iv. 1969, L (USNM). Stratford Co.: Lee, 7.vi.1965, 1 (INHS); same, 30.vi (fide Morse and Blickle, 1953). NEW JERSEY-Bamber Lake: 31.iii.1962, L; same, 22.iv.1962, L (USNM). Mt Misery, 16.ix.1962, L (USNM). Ocean Co.: Lakehurst, Wrangle Brook, 16.v.1962, PP P (USNM); sphagnum bog, 16.v. 1962, P (ROM); Wrangle Brook Rd, 20.vi. 1955, 1 d; same, 23.vi.1955, 1 ㅇ (cU); Old Hurricane Brook on Beckerville Rd, 19.viii.1975, L (GAs); trib. to Middle Br. at bridge on Dover Rd, 17.viii.1975, L (KSBS). NEW YORK-Herkimer Co., Old Forge, 31.vii.1905, 1 ; same, 18.viii.1905, L (cu). Nassau Co., Sea Cliff, vi, lectotype $\delta$ (fide Banks, 1899). Sullivan Co., Roscoe, \#5, 4.iv. 1959, PP (OSF). Tompkins Co.: Ithaca, Mud Cr. nr Freeville (fide Lloyd, 1921); McLean, vi, 2 \& P, 1 \& (cu); 1 mi. e. McLean, Sphaerium Brook, Lloyd-Cornell Reservation, 16-23.vi, adults (fide Sibley, 1926); Termonch L., Trout Branch, \#4, 4.iv.1954, PP (OSF). NORTH CAROLINA-Avery Co., Stacked Rock Cr. at F. S. Rd 192. 3.5 km s. F. S. Rd 1514, xii.1975, L (CLEM). Blue Ridge Parkway: milepost 250.7, 17.ix.1958, L (OSF and ROM); milepost 251, 22.v.1959, L PP P, 1 ơ 4 ㅇ (OSF); spring, 2.ix.1959, L (OSF); sm. str. above falls, 2.ix.1959, L (ROM). Buncombe Co.: Bent Cr. nr Asheville, 4 o; same, 20.v.1950, L, 1 d; same, 21.v.1950, 1 \%; same, 22.v.1950, 2 б; same, 23.v.1950, 1 d; same, 24.v.1950, 3 o 1 q ; same, 26.v.1950, 8 o 6 우 ; same, 29.v.1950, 2 ठै; same, 10.v.1951, ठै P; same, 13.v-2.vi.1951, ठే ठే; 
same, 14.v.1951, 1 б; same, 15.v-2.vi.1951, 우; same,

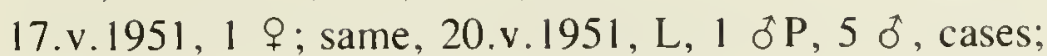
same, 21.v.1951, 1 \%; same, 22.v.1951, 2 đ; same, 13.vi.1951, 1 J; same, 16.vi.1951, 1 q; same, 25.v.1953, 1 q (CU); Black Mtn, 13.v.1952, 1 q; same, 15.v.1952, 1 o 5 \%; same, 17.v.1952, 1 o; same, 19.v.1952, 2 우 ; same, 20.v.1952, 1 ठ; same, 21.v.1952,

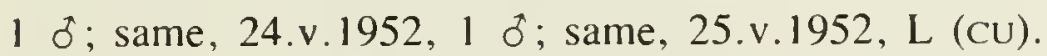
Jackson Co.: Cashiers, Greens Cr., 11.ix.1958, L; same, 14.ix.1958, L (ROM). Macon Co.: Highlands, 38.vi.1961, 5 o 2 \& (USNM); unnamed cr. 4 rd mi. n. Highlands on U.S. Hwy 64, NC \#14, 17.v.1979, P (CLEM); Clear Cr., 10.ix.1958, L (OSF); same, 6.vi. 1961, 1 \& (USNM); Green's Cr., 19.v.1959, P (OSF); Whiteside Cove, 11,14.ix.1958, L (OSF); Highlands Biol. Stn, 1.vii.1958, PP P (OSF); same, 21.ii.1981, PP (CLEM); at Highlands inflow str. s. end L. Revenel, \#12, 17.v.1979, P (CLEM); str. entering reservoir, 26.iv.1980, L (GAS); Nantahala Nat. For., cpgrd, 20.vi.1981, P (CLEM); Skitty Cr., nw. Highlands, 20.vi.1981, L P (CLEM); ca 5 mi. w. Highlands on U.S. 64, NC \#11, 16.v.1979, L PP P (KSBS); same, 31.viii.1980, L (CLEM); same, 20.vi.1981, L P (ClEM). McDowell Co.: Crabtree Meadows, sm. trib. above falls, 2.ix.1959, L (ROM); Blue Ridge Pkwy, 56.vi.1962, 2 o 2 (USNM). Orange Co., Chapel Hill, 1 ๙ (cu). Swain Co., Great Smoky Mtns Nat. Pk: Couches Cr. at Rt. 441, 2.x.1967, L (ROM); Deep Cr. Cpgrd, Juneywhank Falls, 21.v.1970, 1 (ROM 700366); New Found Gap along Little Pigeon R., 13.vi. 1935, holotype d Heteroplectron gameta Ross (fide Ross, 1939);* Smokemont Cpgrd, 11-14.v.1970, 3 \& (OSF); Smokemont Cpgrd at Bradley Fk of Oconaluftee R., 2.x.1967, L (ROM). Transylvania Co.: Davidson R. nr Ecusta. 3 oे; same, 7.v.1952, 1 ठ; same, 14.v.1952, 1 ठ (cu); White Water R. at Rt. 171 n. Salem, 18.v.1970, 2 \& (ROM 700353); same, 2 ㅇ (USNM). Yancey Co.: Black Mtns, Hemphill Spring, $4760 \mathrm{ft}, 1-2 . v i i .1979,1 \delta$ (CLEM); South Toe R., Black Mtn Cpgrd, 8.viii. 1980, L (CLEM); sm. feeder str. ca 3 mi. n. Blue Ridge Pkwy Cpgrd (se. foot of Mt Mitchell), NC \#4, 14.v.1979, PP P (KSBs); sm. trib., Black Mtn Cpgrd, 8.viii.1980, L P (CLEM). PENNSYLVANIA-Carbon Co.: e. Hickory Run St. Pk, Laurel Run crossing Rt. 534, 20.iv.1968, PP (ROM); Swamp Run crossing Rt. 534, 20.iv.1968, L (ROM). Chester Co., Atglen, Glen Run, 2-3.vi.1977, 3 oे (CLEM). Lancaster Co., Welsh Mtn, New Holland Watershed Area, 19-20.vi. 1978, 3 ठ 2

\footnotetext{
* Ross's designation for this locality appears to be in error. Newfound Gap is on the border between North Carolina and Tennessec, but Little Pigeon River is in Tennessee about $10 \mathrm{~km}$ downhill from the Gap. In Tennessee, the nearest named creck to the Gap is Walker Camp Prong; in North Carolina, the nearest named creck is Becch Flats Prong.
}

q (CLEM). Lycoming Co., 5 mi. n. Trout Run, str. beside Rt. 15, 7.v.1968, PP (ROM). Tioga Co., Liberty, 29.v.1939 (fide Hyland, 1948). QUÉBEC-Argenteuil Co., Harrington, str. in Can. Ind. Pulp For., 21.vii.1966, L (ROM). Parc du Mont Tremblant: 16-17.vi (fide Roy and Harper, 1975); Rivière du Diable, 9.vi (fide Robert, 1960); Tremblant, str. 2 mi. nw. Rivière du Diable, 16.vii.1969, L (ROM). Rouville Co., Mont St-Hilaire, West Creek, 1966-1968, L, 3 \& 2 \& (ROM). St-Laurent (fide Roy and Harper, 1979). Système du St-Laurent, des Outaouais (fide Roy and Harper, 1979). SOUTH CAROLINA-Barnwell Co.: Savannah R. Plant, Upper Three Runs Cr. at SRP Rd 8-1, 4.xii.1976, L; same, 29.jii.1977, 2 ठే; same, 12.iv.1977, 1 q; same, 3.v.1977, 2 q; same, 1213.iv.1979, 2 \&; same, 27.x.1979, L; same, 8.i.1980, PP; same, 7.ii.1980, PP; same, 24.iv.1980, P, 1 q; same, 4.x.1980, L; same, 18.x.1980, L (CLEM). Oconee Co.: Chattooga R., e. fk, U.S. Fish Hatchery, 28.iii.1980, PP; same, 2.iv.1981, L; same, 29.v.1981, 1 q MMT (CLEM); Chattooga R. at Ellicott's Rock, 27.ix.1978, L (CLEM); Crane Cr. at Tamassee Rd 3.8 mi. e. SC \# 107, 7.ix.1980, L (CLEM); n. Salem on Rt. 171, glades area, 18.v.1970, L (ROM 700352); Stumphouse Tunnel, $7 \mathrm{mi}$. w. on SC \# 107 from SC \#28, 22.xi.1976, L (CLEM); 6 mi. s. Walhalla, Crane Cr. n. Tamassee, U.S. Fish Hatchery, 2627.v. 1980, 2 o (CLEM); s. Walhalla Fish Hatchery and Rt. 109, str. crossing rd to Burrell's Ford Cpgrd, 19.v. 1970, L PP P (RoM 700351). Pickens Co.: Clemson, trib. Camp Cr., 20.iii.1963, P (Clem); $9 \mathrm{~km}$ nw. Clemson, Clemson Univ. For., Wildcat Cr., 1968-1969, 1 đ 1 \%; same, 28.iii.1973, L P; same, 22.ix.1976, L; same, 22.ix.1976, L; same, 21.ix.1978, L; same, 21.ix.1978. L; same, 5.x.1978, L; same, 11.iv.1979, PP; same, 5-6.v.1979, 5 ठ; same, 5.x.1979, L; same, 13.iv. 1981. L PP P. 7 o $7 q$ MMT (Clem); Fox Cr., Six Mile, 18.x. 1967, L; same, 1819.x.1977, L; same, 19.x.1977, L (CLEM); Indian Cr., Issaqueena For., 13.iv.1979, P (CLEM); Rock Quarry, 28.iii.1968, L (CLEM); Six Mile Cr., 8.ix.1965, L (Cl.EM); Wildcat Cr., 24.ix.1975, L; same, 5.5 mi. nw. Clemson, 28.iii.1973, L P (CLEM). Sumter Nat. For.: str. in Yellow Branch Picnic Area, ca $1500 \mathrm{ft}, 19 . \mathrm{v} .1970$, L P. $1 \delta$ (USNM); same, L P, 1 đ (ROM 700356). TENNESSEECarter Co., Roan Mtn St. Pk, outflow of seepage area nr trib. Dave Miller Hollow Branch, 7.v.1977, L P (UT). Davidson Co.: Little Marrowbone Cr., 14.iv.1954, L: same, 14.iv.1955, 1 q; same, 2.v.1955, 1 q (fide Edwards, 1966). Dickson Co.: Montgomery Bell St. Pk. str. at entr., 17.iv. 1955, L (fide Edwards, 1966); Greenbriar Cove, 4.iv.1941, L P (OSF). Monroe Co., str. at Betsy Coker restaurant, Rt. 68, 22.iv.1977. P (UT). Sequatchie Co., Sequatchie R., 26.vii.1953, L (fide Edwards, 1966). Sevier Co., e. slope of Webb Mtn. George Cox property, 17.iv-17.v.1975, 2 o (GAs). Great Smoky Mtns Nat. Pk: Cole Branch of Little R. at Rt. 441. 
I.x.1967, L (ROM); Jakes Branch nr Elkmont Cpgrd, 10.iv.1981, L (GAS); Little R. at Elkmont Cpgrd, 10.iv. 1981, L (GAS); spring $0.5 \mathrm{mi}$. n. Greenbriar Ranger Stn, 1.iv.1977, L (KSBS). Unicoi Co., pond $2 \mathrm{mi}$. up Rocky Fork Cr., U.S. 23, 7.v. 1977, L P (UT). Williamson Co., Leipers Fork Cr., 24.vii.1953, L (fide Edwards, 1966). VERMONT - L (cu). Windsor Co., just s. West Bridgewater, sm. str. crossing Rt. 100, 26.vii.1969, L (ROM 690376). VIRGINIA-Str. on Rt. 104, 0.4 mi. e. junction with 22, 2.v.1970, 1 of (INHS). Fairfax Co., George Mason Univ., 11.vi.1973, 1 ठ (INHS). Fauquier Co.: Catharpin Cr., Jackson Hollow, 8.v.1962, PP P; spring, 10.v. 1974, L PP P; upper springs and creek, Rt. 629, 9.vi.1962, L P, 1 ơ 1 q (USNM). Frederick Co., 8 mi. nw. Winchester, vi. 1976, L (UsNM). Giles Co., Hunter Cr. at Mountain L. Biol. Stn, 18.iv. 1968, L (ROM). Grayson Co., Laurel Cr., Rt. 603, 22.iv.1979 (emerged 14.v. 1979), P. 2 o 1 ㅇ (vPI). Rockbridge Co., Cave Mtn Lake Area \# 12, 29.iii. 1957, PP (OSF). Shenandoah Nat. Pk, Skyline Dr. milepost 79, 24.vi. 1961, P (USNM). Smyth Co.: Hungry Mother St. Pk, Marion, 26.iv.1979, PP P (UT); n. side White Top Mtn, 21 mi. n. Grayson Co. Line on s. side Virginia Co. Rd 600, sm. str., Va \#2, 11.v.1979, L (ksBs); Jefferson Nat. For., Mt Rogers, sm. str. and seepages 1.4 mi.n. Grayson Co. Line on Rt. 600, Va \# 1, 10.v. 1979, L (KsBs); sm. str. nr trail to Mt Rogers, Grindstone Cpgrd, Va \#4, 11.v.1979, PP (KSBS). Spotsylvania Co., unnamed trib. Massaponax $\mathrm{Cr}$, 1 mi. s. 4-mile Fork, Rt. 208, P (UsNm). Washington Co., Straight Branch, Beartree Camp, 12.vi.1979, 1 के 1 으 (USNM).

\section{Psilotreta labida Ross}

Psilotreta labida Ross, 1944:287, fig. 954A,C. Holotype ơ (INHS), Cedar River near Indian Lake, Adirondack State Park, New York.

Adults of this species are separated from $P$. indecis $a$ and $P$. frontalis by the modified maxillary palpi and unmodified posterior warts on the head of the male, and by details of the genitilia of both sexes as set out in the key. The larva can be distinguished by the acute projection of the anterolateral corner of the pronotum, the long, blunt mesepisternal projection, the extension of the black marking of the posterior ridge of the mesonotum at least as far as the posterior inflection, and the colour pattern.

\section{ADULT}

Frontoclypeus of female as in $P$. indecisa; frontoclypeus of male similar to that of $P$. frontalis but with patches of scales less dense. Maxillary palpi identical with those of $P$. frontalis in both sexes. Head of male lacking large, scale- covered eversible lobes, instead with pair of lunate setal warts (as in Fig. Ia). Male with setae on undersurface of anal area of hindwing slightly flattened.

Male genitalia (Fig. 15). Segment VII with pleural membranes bearing a distinct enlarged lobe posteriorly. Segment IX lacking posteriorly projecting style; inferior appendage with apical segment bearing two to five short, stout black teeth laterally and apically and one long, pointed, mesally directed tooth, which (rarely) may be paired. Segment $X$ similar to $P$. indecisa and $P$. frontalis.

Female genitalia (Fig. 16). Anterior portion of sternum IX heavily and uniformly sclerotized; posterior vaginal sclerites heavily sclerotized and broad.

LARVA (Figs. 27, 34)

Colour pattern similar to $P$. indecisa, but dorsal black stripe of head much broader posteriorly with little or no taper from front to rear; extent of light and dark areas variable among populations, some having light areas reduced as to appear almost completely black, others with light areas very large so that nota are predominantly light.

Pronotum with projection of anterolateral corner acute, shorter in most specimens of $P$. labida than in most specimens of $P$. indecisa but with the same range of size overall. Mesonotum with posterior ridge black as far as posterior inflection, black stripe extending ventrally past inflection to ventral edge of sclerite; mesepisternum with anteroventral projection long and narrow. Metanotum (Fig. 34) with anterior sclerite bearing 29-66 setae, posterior bearing 17-30, each lateral bearing 24-43. Abdominal segment VIII bearing 8-18 lateral tubercles on each side. Abdominal gills: dorsal-II 20-32, III 28-46, IV 1828, V 14-29, VI 10-29, VII 5-16, VIII 0-10; lateral-II 0-6, III 0-9; ventral-II 13-28, III 24-34, IV 18-33, V 18-30, VI 16-27, VII 16-25, VIII 13-16. Larva up to 13 $\mathrm{mm}$ in length; head up to $1.2 \mathrm{~mm}$ in width across eyes. Larval case up to $16 \mathrm{~mm}$ in length.

\section{HABITAT AND BIOLOGY}

As discussed under $P$. frontalis, many of the published observations on the habitat and biology of that species actually refer to $P$. labida, or to mixtures of $P$. frontalis and $P$. labida. We have found that larvae of $P$. labida occur in small spring-fed streams $1-3 \mathrm{~m}$ wide and in large rivers at least $15 \mathrm{~m}$ wide. Larvae are found on the sides and lower surfaces of rocks and are notable for their markedly gregarious habits at pupation. In large populations it is not uncommon to find a single rock with several layers of pupal cases attached one atop another with old cases from previous years still attached on the lower layers. 

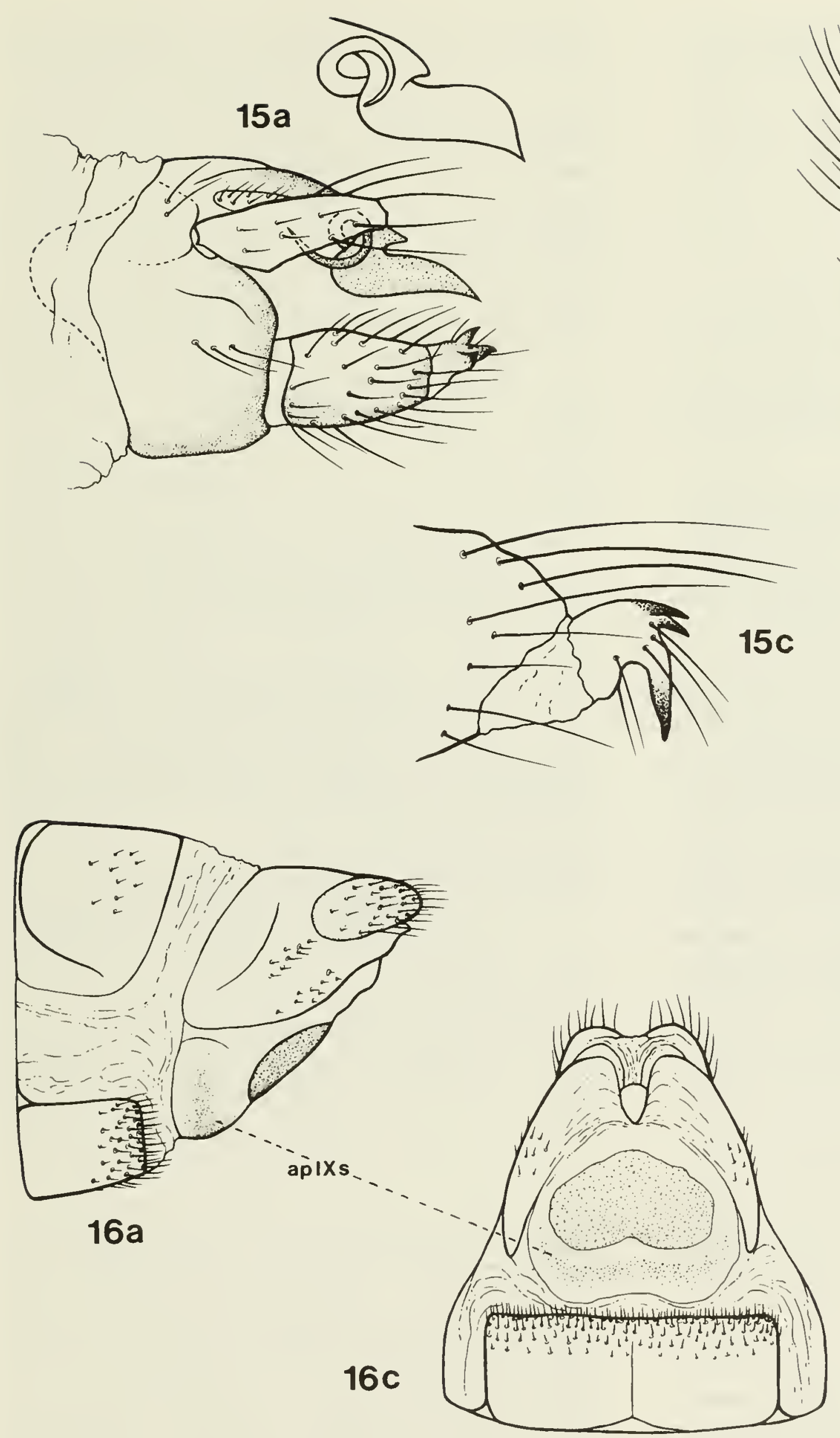

$16 b$

$16 d$
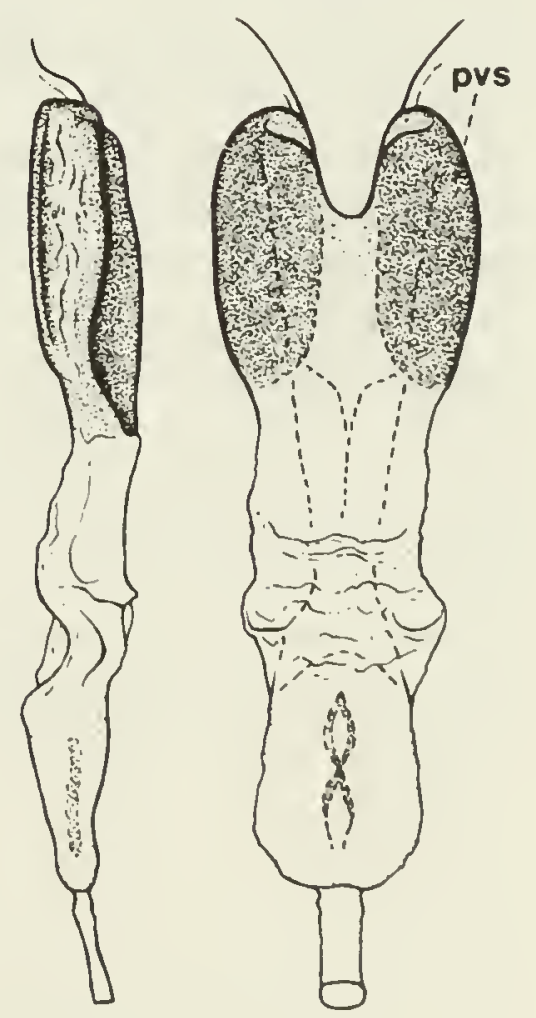

Figs. 15, 16. Psilotreta labida. 15, a,b, o genitalia-lateral (with detail of variation in lateral process of segment X), dorsal: c, apical segment of inferior appendage-ventral. I6. a.c. I genitalia-lateral, ventral; b.d, vaginal apparatus-lateral, ventral (aplXs-anterior portion of sternum IX; pvs-posterior vaginal sclerite). 
DISTRIBUTION (Fig. 38)

$P$. labida has a more restricted range than $P$. indecisa or $P$. frontalis, extending neither as far north nor as far south: Connecticut, Georgia, Kentucky, Maine, Maryland, Massachusetts, New Hampshire, New Jersey, New York, North Carolina, Pennsylvania, Tennessee, Virginia, West Virginia

\section{MATERIAL EXAMINED AND ADDITIONAL RECORDS} CONNECTICUT-Tolland Co., Storrs, 10.vi.1954, 1 q (INHS). GEORGIA-Rabun Co., Tate City, Tate Br. Cpgrd, 17.v. 1970, P (preserved 22.vi. 1970) (ROM). KENTUCKY-McCreary-Wayne Co. Line, Little S. Fork at Cumberland R., mi. 12.5 at Corder Cr., 1.xi.1980, L (GAS). MAINE-Penobscot Co., Passadumkeag, 29.vi.1956, I 우 (CU). MARYLAND-Garrett Co.: 6.vi.1931, paratype ơ (USNM); ca $1.5 \mathrm{mi}$. e. Friendsville, river beside rd, 9.v.1968, P (ROM). MASSACHUSETTS-Hampshire Co.: N. Amherst, Cushman Br., 4.v.1954, PP (OSF); Middlefield, Factory Brook, v, vi, ơ के (fide Neves, 1979); Pelham, 10.vi.1939, I के (DGD); Williamsburg, Rt. 143, 16.vi. 1958, L PP P (OSF). NEW HAMPSHIRE-Coos Co.: Ammonoosuc R., Zealand Camp, \#11, 11.vi.1957, PP; same, 25.viii. 1957, L (OSF); Jefferson, 28.vi.1965, 8 o 2 우 (INHS); Dundee, \#26, 14.vi.1957, P (OSF). Grafton Co., Whitcheville Brook nr Benton, 21.vi.1941, 2 o paratypes (fide Ross, 1944). Stratford Co.: Durham (fide Morse and Blickle, 1953); Lee (fide Morse and Blickle, 1953). NEW JERSEY-Passaic Co., Passaic, 8.vi, 1 ơ (MCZ). Sussex Co., Stokes St. For, beaver pond at Big Flatbrook $\mathrm{Cr}$. by Steam Mill Camp, 3.ix.1975, L (KSBS). NEW YORK-Adirondack St. Pk: Cedar R. nr Indian L., 20.vi. 1941, holotype ठ, allotype,+ 2 o 1 ㅇ paratypes (fide Ross, 1944); small cr. nr Tahawus, 20.vi.1941, paratype o (fide Ross, 1944). Albany Co., Nassau, 2.vi.1906, 2 o I $q$ (cu). Beaverkill R., e. branch, 6.vii.1959, L (OSF). Chemung Co., Van Etten, McCorn Cr. CYL-5, 27.viii.1975, L (CU). Delaware Co.: Beaverkill R. at Rt. 17 (exit 92) nr Simcoe Stn, 19.v. 1979, L PP (Rом 790002); same, 22.v. 1979, P (ROM 790003); Horton, emerged 8.v.1976, 2 o 1 웅 same, 5.vi.1966, 4 ơ 4 ; 2 ㅇ (USNM). Hamilton Co., Wells, 17.vi.1925, I ò (cU). Sacadaga R., Sport Isl., 19.vi.1900, 1 đ (MCZ). St Lawrence Co.: Ogdensburg, 11.viii. 1906, L; same, 21.viii, empty cases (CU). Steuben Co.: 4 mi. wnw. Avoca (just w. Bloomerville), Castle Cr. \#14, 17.viii. 1978, L (kSBS); same, 29.xii. 1977, L (KSBs). Sullivan Co.: Rockland, 1,2,4.iv.1959, L; same, 6.vi.1959, P; same, 6.xii. 1959, L PP (OSF); Roscoe, Little Beaverkill R., 13.ii.1977, L 13 of o MMT (USNM); same, 6.vi.1959, P (OSF). Tompkins Co.: Danby, Michigan Hollow Str., 3.vii. 1959, L; same, 23.ix. 1956, L (OSF); Freeville, 7.ii.1915, 1 ; same, 6.vii.1913, I के 1 (CU); 1thaca, 8.vi, I $q$ (CU); McLean, 1 \%; same, 2.vi, L P; same, 28.vii, ठP (cu); same, 13.vi. 1935, paratype ठ (fide Ross, 1944); same, 1.v.1959, PP (OSF); McLean Bogs Reserve, 3.vi.1939, 2 으 (cU); McLean Reserve, Sphaerium Brook, 22.vi.1956, P (OSF); same, 29.v. 1959 (preserved 23.vi. 1959), L P (ROM); same, PP (OSF); Mich. Swamp, 6.x.1914, I $q$ (CU); Slaterville Springs, Wildflower Preserve, 7.vi.1958, P (OSF). Warren Co., North Cr., 4.vii.1918, 1 \& (CU). NORTH CAROLINA-Buncombe Co.: Black Mtns, 31.v-4.vi.1912, 1 ; same, vi.1912, 1 o (CU); Swannanoa, 26.v.1933 (fide Denning, 1950). Swain Co.: Great Smoky Mtns Nat. Pk, 7.vii.1961, 2 ठै 2 \% MMT (USNM); Bryson City, Deep Cr. at Deep Cr. Cpgrd, 13.ix.1958, L; same, 21.v.1970, L PP P (ROM 700365). ONTARIO_Grey Co., North Spey R., Hwy 10 just s. Rockford, 21.v.1976, P (ROM). PENNSYLVANIA-3 $q$ (CU). Monroe Co.: Analomink, 6.vi.1907,

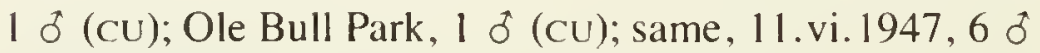
6 f (CU); nr Swiftwater (Lot 258), 1928, 2 o 1 q paratypes (fide Ross, 1944). Potter Co., $10 \mathrm{mi}$. n. Coudersport, str. crossing rd $0.5 \mathrm{mi}$. w. Rt. 44, 15.iv. 1968, L (ROM). Union Co., Penn's Cr., 16.v.1938, paratype ठð (fide Ross, 1944). Wayne Co., Gouldsboro, 19.ix.1958, L (ROM). TENNESSEE-Blount Co., trib. to Little R. at Townsend, 19.ii.1973, L P (UT). Cheatham Co., Big Marrowbone Cr., 2.v.1954, 2 ơ (fide Edwards, 1966). Davidson Co., Little Marrowbone Cr., 15.iv. 1954, adults (fide Edwards, 1966). Dickson Co.: str. at entr. to Montgomery Bell St. Pk across U.S. 70, 18.iv.1955, 1 б (fide Edwards, 1966); same, 2.v. 1975, L P (UT); same, L P (GAS). Franklin Co., $4 \mathrm{mi}$. W. Winchester, Wellington Mills, Owl Hollow Cr. 1.5 mi. n. Rt. 50, 14-15.v. 1970, L PP P (ROM 700338). Grundy Co., Monteagle, 12.vi, 1 우 (CU). Hamilton Co., Chattanooga, Rt. 11, Sta. 8, Tenn. \#490a, 17.xii.1956, L (USNM). Marion Co., Martin Spring, 1.viii.1955, L, 3 \% 6 \& (fide Edwards, 1966). Overton Co.: 0.5 mi. w. Alpine on Rt. 52, Means Cr., 30.ix.1967, L; same, 13.iv.1978, L (ROM 780063). Pickett Co., 7.2 air mi. n. Jamestown, Wolf R., second bridge on county rd off U.S. 127, 22.x.1977, L (UT). Sevier Co.: Elkmont, fk Little Pigeon R., 27.v. 1934, paratype ô (fide Ross, 1944); e. slope Webb Mtn, George Cox property, 17.iv-17.v.1975, 2 o (UT). Wayne Co., Eagle Cr. at dirt rd $6.1 \mathrm{mi}$. from Lookout Tower off Clifton Turnpike (between Tenn. \#114 and U.S. 64), 15.iii.1972, L (UT). VIRGINIA-Bath Co., ca 5 mi. n. Mountain Grove, Back Cr. on Rt. 600, 2.vi.1972, I đ (USNM); Curles Neck Bridge, 19.iv.1938, paratype ठै (fide Ross, 1944). Giles Co.: Little Walker Cr. at Rt. 100 s. Pearlsburg, 10.viii.1968, L (ROM); White Gate, Walker Cr., 29.ix. 1977, L (USNM). Hyland Co.: e. fk Potomac R., Rt. 220, 18-20.v.1963, P, I ठ (USNM); 5 mi. sw. Monterey, Jackson R. beside Rt. 84, 5.x.1967, L (ROM). Madison Co., Graves Mill, Rapidan R., 800 ft, 18.iv.1975, L 
(USNM). Montgomery Co.: Mill Cr., Rt. 785, 29.iii.1977, $\mathrm{P}$ (emerged 15.iv.1977), 3 oै 1 \&; same, 11.iv.1978 (emerged and preserved 28.iv. 1978), L PP P, 7 क 2 q (USNM); same, 1 o 1 (ROM). Rockbridge Co.: nr Cave Mtn Area, \#25, 11.ix. 1957, L (OSF); Greys Run, Goshen Wildnerness Mgmt Area, 11.vi.1977, 1 o (vPI). Shenandoah Nat. Pk: Pass Run, 11.vi.1961, L PP P, 1 đ MMT (USNM); Thornton R., 8.vii.1961, PP P; same, 27.v.1962, P (USNM). Smyth Co., Crewey Br., Rt. 610, 30.iii.1979, 10 of 11 q (VPI). Wythe Co., $1.8 \mathrm{mi}$. w. Wytheville, Reed Cr. at Rt. 11, 4.x.1967, L (ROM). WEST VIRGINIAPendleton Co., Gandy Cr., Spruce Knob, 22.vi.1973, 1 ठ (USNM).

\section{Psilotreta rufa (Hagen)}

Molanna rufa Hagen, 1861:276. Lectotype ð (MCz), Trenton Falls, New York, Osten Sacken, 1858.

Heteroplectron? dissimilis Banks, 1897:30. Lectotype q (MCZ), Sea Cliff, Long Island, New York, vi. NEW SYNONYMY.

Astoplectron connexa Banks, 1914:265.

Molarnodes rufa-Milne, 1934:9, 11.

Heteroplectron indecisum-Milne, 1936:57, 80.

Heteroplectron rufa-Ross, 1938:20, as synonym of $P$. indecisum.

Psilotreta rufa-Ross, 1944:286-287, 300, fig. 952A-C; A. connexa synonym of $P$. rufa.

Psilotreta rufa-Wallace, 1970:244, fig. 4.

Psilotreta rufa-Schmid, 1983:48, figs. 278-282.

This species is distinguished from others in the rufa subgroup by the details of genitalia given in the key. The larva is distinguished by the shape of the head and of the anterolateral corner of the pronotum and by the condition of the setae as outlined in the key.

\section{ADULT}

Forewing 9-11 mm in length. Coloration almost uniformly dark reddish brown with antennae, legs, and abdomen paler. Antennae long and slender, 1.2-1.7 $\times$ forewing length; scape 3.5-4.0 $\times$ pedicel length; first two fused segments of flagellum 2.3-2.7 $\times$ pedicel length. Maxillary palpi with first two segments subequal in length, approximately three-quarters length of third and fourth segments, and fifth segment about twice length of first. Labial palpi short, with many short setae, first segment two-thirds length of second, and one-half length of third. Frontoclypeus with large convex wart medially, covered with long setae projecting dorsally. Vertex with anteromesal setal warts very small or absent; anterior warts divided into numerous small areas arranged transversely behind anteromesal warts, with largest contiguous areas laterad; posterior setal warts large, discrete, and transversely lunate.

Male genitalia (Fig. 17). Abdominal segment VII with pleural membrane unmodified. Segment IX with apical segment of each inferior appendage bearing three to six sharp black teeth apicomesally. Segment X with dorsomedian lobe rarely extending beyond midlength of lateral processes in dorsal aspect, and with apex entire or bifid and bearing a few to several setae; lateral processes triangular in dorsal aspect, highly variable in lateral aspect, ranging from simple broad, bluntly rounded plates to narrow, sinuous plates with a pronounced apicoventral projection (Fig. 17a).

Female genitalia (Fig. 18). Anterolateral region of sternum IX lacking indentations, but this area may appear slightly granular. Posterior vaginal sclerites with mesal edges approximate posteriorly, diverging rapidly, and widely separated anteriorly.

LARVA (Figs. 8, 28, 29, 35)

Sclerites uniformly reddish brown, although posterior sclerites may be lighter than more anterior sclerites. Head longer than wide (Fig. 35), and in lateral aspect posterodorsal angle more or less squared; dorsum relatively flat between carinae (Fig. 29b); seta 17 thinner than, and usually about one-half as long as, seta 15 (Fig. 29a). Pronotum with projection of anterolateral corner short, about $0.2 \times$ middorsal length of pronotum. Mesonotum with black marking along posterior ridge extending laterad to posterior inflection; mesepisternum lacking projection of anteroventral corner. Metanotum (Fig. 35) with anterior sclerite bearing 60-67 setae, posterior bearing 21-30, each lateral bearing 35-43. Abdominal segment VIII bearing 0 10 lateral tubercles on each side. Abdominal gills: dorsalII 12-16, III 13-17, IV 9-13, V 7-10, VI 4-7, VII 3-6, VIII 0-3; ventral-II 9-I1, III 16-20, IV 12-16, V 8-12, VI 9-11, VII 0-11, VIII 0-4. Larva up to $12 \mathrm{~mm}$ in length; head up to $1.1 \mathrm{~mm}$ in width across eyes. Larval case up to $11 \mathrm{~mm}$ in length.

\section{NOTES}

We examined the female lectotype of Heteroplectron? dissimilis Banks, 1897, and found it to be identical with females of $P$. rufa. We therefore place $H$. dissimilis as a junior subjective synonym of Psilotreta rufa (Hagen).

\section{HABITAT AND BIOLOGY}

$P$. rufa larvae occur in small spring seeps and spring-fed streams. Graham (1982) studied a small population in a spring seep in southeastern Pennsylvania; larvale required 


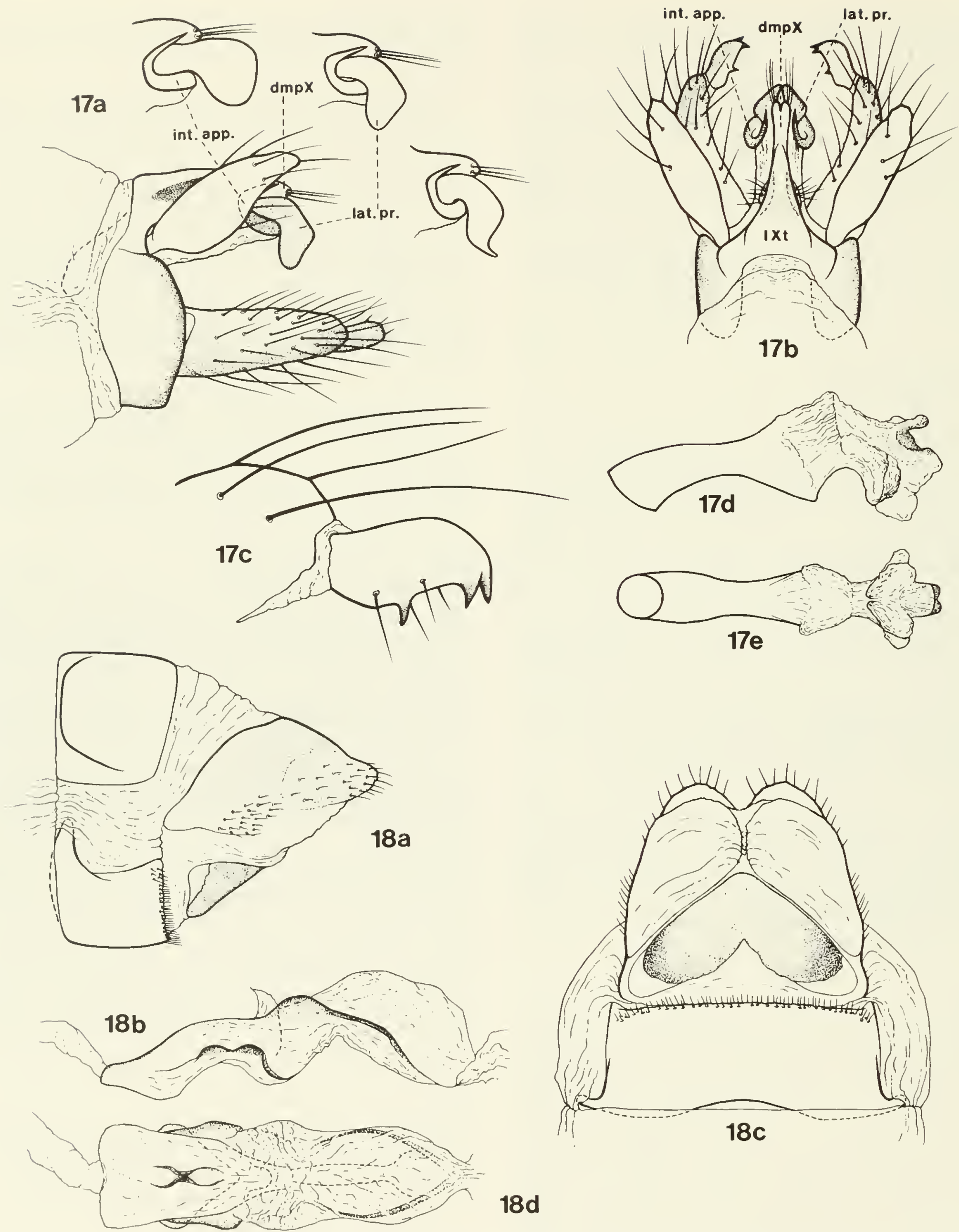

FIGS. 17, 18. Psilotreta rufa. 17, $a, b, \delta$ genitalia-lateral (with detail of variation in lateral process of segment X), dorsal; $c$, apical segment of inferior appendage - ventral; $d, e$. phallus-lateral, ventral (dmpXdorsal median process of segment X; int. app. - intermediate appendage; IXt—tergum of segment :X; lat. pr.-lateral process). 18. a,c, + genitalia-lateral, ventral; $b, d$, vaginal apparatus-lateral, ventral. 
two years to complete development, growth was temperature-dependent, occurring from May to October, and optimum growth was at $15^{\circ} \mathrm{C}$ which was reached during early spring and late fall.

\section{DISTRIBUTION (Fig. 39)}

This is the most widely distributed of the three species of the rufa subgroup: Alabama, Delaware, Kentucky, Massachusetts, Mississippi, New York, North Carolina, Pennsylvania, Tennessee, Vermont, Virginia.

\section{MATERIAL EXAMINED AND ADDITIONAL RECORDS}

ALABAMA-Cleburne Co., trib. Shoal Cr. $5.8 \mathrm{mi}$. from Ala \#73, R9E-T155-28NW, 22.iv.1973, 1 ठ (UT). DELAWARE-New Castle Co. (fide Lake, 1984). KENTUCKY-Mammoth Cave Nat. Pk, Good Spring, 20.v.1957, 5 ơ (1NHS). MASSACHUSETTS-Berkshire Co., Mount Greylock, I5.vi, I ơ (ROM). MISSISSIPPILafayette Co., $6 \mathrm{mi}$. e. Oxford, Hopewell L. (fide Holzenthal et al., 1982). Marshall Co.: Wall Doxey St. Pk, Rt. 7 s. Holly Springs, sm. spring str., 12.v.1970, L (ROM 700332); Spring Lake, v (fide Holzenthal et al., 1982); w. side Spring Lake, spring seep, 15.v. 1980, L (CLEM); same, 16.v. 1980, L (Paul Lago, University of Mississippi). Tishomingo Co., luka (fide Holzenthal et al., 1982). NEW YORK-Tompkins Co.: Ithaca, Dryden, Ellis Hollow, spring, 4.x.1956, L; same, 31.i.1957, L; same, 17.ii.1957, PP; same, 12.iii.1957, L (OSF); same, 11.vi.1956, 1 б (ROM); Ellis, spring, 5.v.1956, L; same,

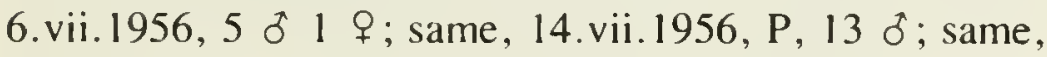
17.ix.1956, L (OSF); Ellis Hollow Rd, spring seepage, 29.v. 1959, PP (ROM); same, 23.vi.1956, P (OSF). NORTH CAROLINA-Macon Co.: trib. Chattooga R. e. Highlands, \#2, 6. vii. 1958, L (OSF); str. feeding Cliffside L. (Skitty Cr.) at cpgrd ca $6 \mathrm{mi}$. nw. Highlands, 27.iv. 1980, L PP (GAS). Transylvania Co., n. Salem, White Water R. at Rt. 171, 18.v.1970, P (ROM 700353). PENNSYLVANIA-Chester Co.: Atglen, Glen Run, 2.iv. 1977, P; same, 24.iv.1977, L PP P, \& MMT; same, 2-3.vi.1977, 14 ơ 1 \& (CLEM). Fulton Co.: Chestnut Bridge Hollow, 21.vi.1976, L P (CLEM); Crystal Spring, 29.vi.1976, I ठै I \& MMT; same, 31.vii.1976, 1 ơ (CLEM). TENNESSEE-Chester Co., at spring ne. Henderson, 21.vi.1959, 1 ơ (INHS). Franklin Co.: Wellington Mills, 19.iv.1955, 1 ठ; same, 26.iv.1955, 2 o; same, 30.iv. 1955, I o (fide Edwards, 1966). Hardin Co., Cave Hollow Br. of Turkey Cr., 15.v. 1978, P (uT). Sevier Co., Great Smoky Mtns Nat. Pk, str. 10.2 mi. e. Gatlinburg entr. on Rt. 44l, 20.v.1970, PP (ROM 700361). VERMONT-Windham Co., Brattleboro, 14.vii, I đ (ROM). VIRGINIA-Albemarle Co., s. fk Mooremans R. above Charlottesville Reservoir, 13.iv.1974, PP (USNM). Shenandoah Nat. Pk: Ivy Creek, 2700 ft, 18.ix. 1958, L (ROM); Piney R., 1100 ft, 28.v.1977, 6 o I ㅇ (USNM). Skyline
Drive, milepost 79, 18.ix.1958, L; same, milepost 79.5, 23.v.1959, PP P; same, milepost 79.6, \#27, 12.ix.1957, L (CLEM).

\section{Psilotreta rossi Wallace}

Psilotreta rossi Wallace, 1970:243-245, figs. 1-3. Holotype $\delta$ (INHS), Coweeta Hydrological Laboratory, Macon County, North Carolina.

Adults of this species are distinguished from other North American Psilotreta by their pale grayish coloration, the open discal cell in the hindwing of the female, and details of the genitalia of both sexes as outlined in the key. The larva is distinguished by the very small projection of the anterolateral corner of the pronotum and the short head seta 17.

\section{ADULT}

Forewing 9-10 mm in length. Coloration pale yellowish to grayish brown, abdomen purplish. Antennae 1.4-1.5 $\times$ forewing length; scape 4.5-5.0 $\times$ pedicel length; first two fused flagellar segments $3.0-3.3 \times$ pedicel length. Palpi identical with those of $P$. rufa except male maxillary palpi with a few dark, scalelike setae ventrally along length of first two and base of third segments. Frontoclypeus with median wart narrower than in $P$. rufa and constricted below middle; vertex with anteromesal warts larger, anterior warts smaller and narrower, and posterior warts more triangular than in $P$. rufa. Hindwing of female with discal cell open apically.

Male genitalia (Fig. 19). Abdominal segment VII with pleural membrane unmodified. Segment IX with apical segment of inferior appendage not truncate in lateral or ventral aspects (Fig. 19c), and with mesal surface concave and possessing a sharp black tooth on the basomesal corner and one to three teeth apically. Segment X with dorsomedian lobe almost always extending beyond midlength of, and often entirely beyond apex of, lateral process in dorsal aspect, apex bifid and bearing several setae (Fig. 19b); lateral processes semicircular or triangular in dorsal aspect, short and broadly rounded apically, with a narrow posteriorly curved projection from the apicoventral border in lateral aspect (Fig. 19a), this projection moderately long and blunt; intermediate appendages as in $P$. rufa.

Female genitalia (Fig. 21). Anterolateral corner of sternum IX with a small depression; posterior vaginal sclerites broadly oval and lightly sclerotized.

LARVA (Figs. 30, 36)

Head and pronotum dark reddish brown, mesothoracic and 

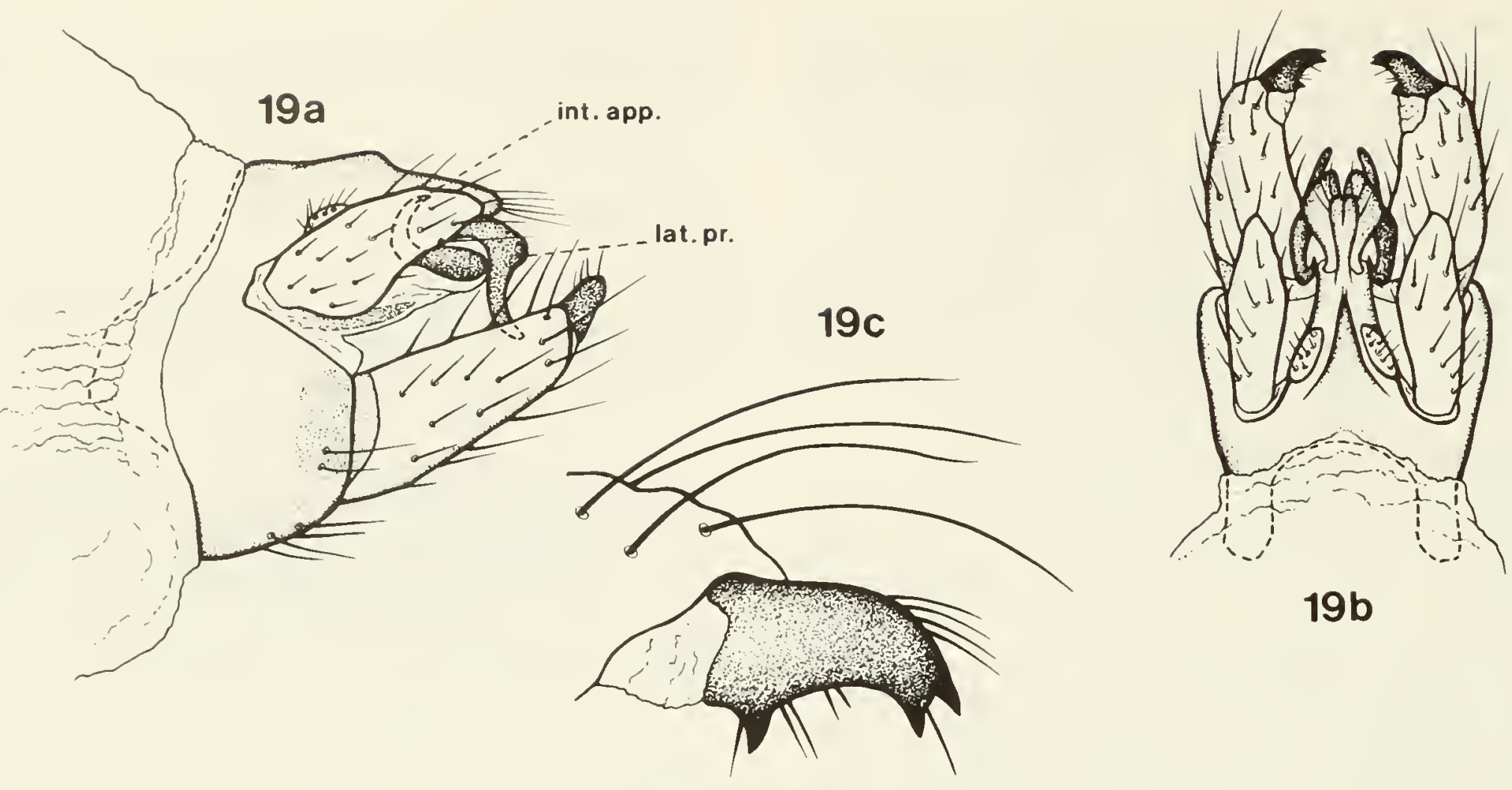

$19 b$
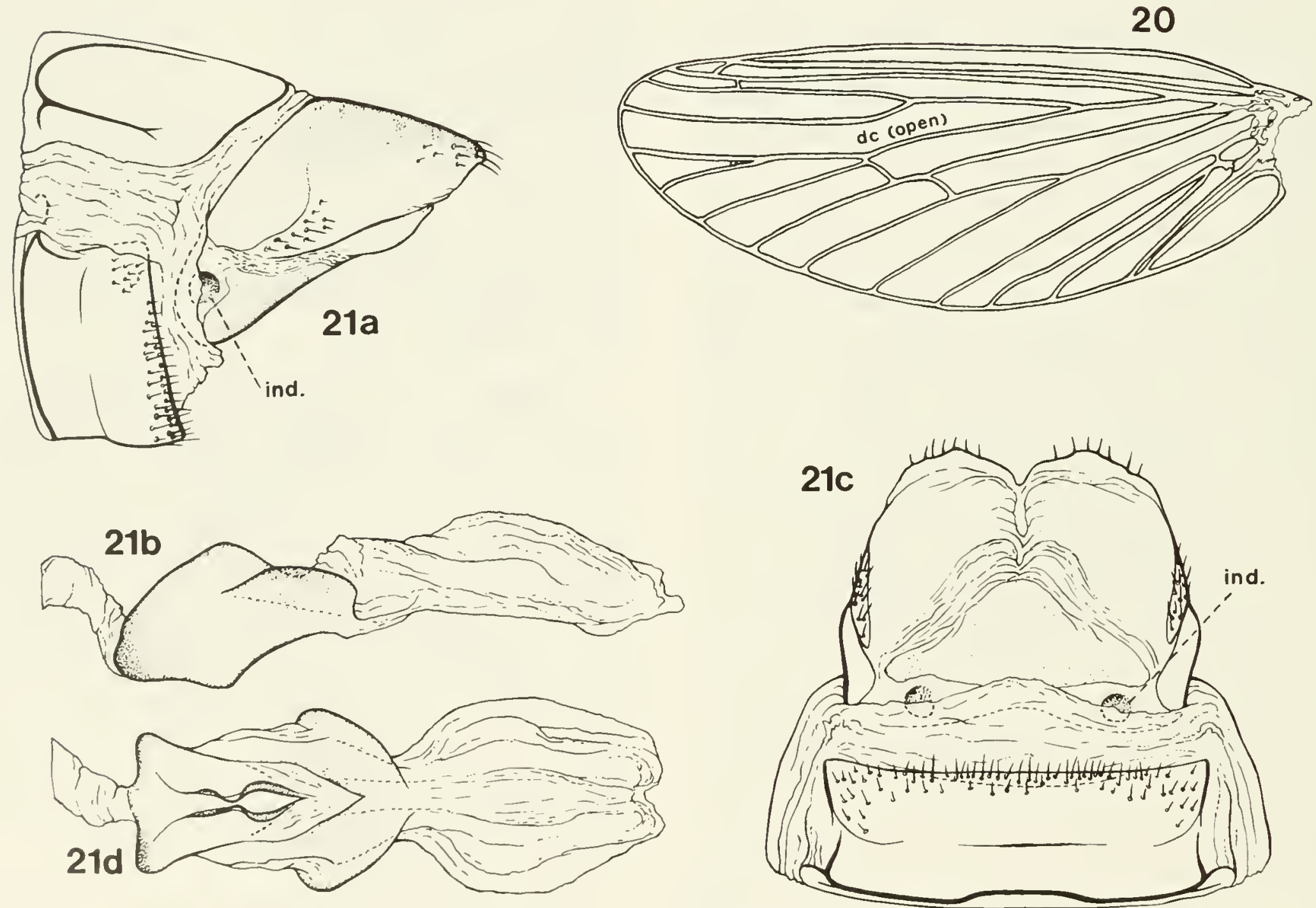

Figs. 19-21. Psilotreta rossi. 19. $a, b, \delta$ genitalia-lateral, dorsal; $c$, apical segment of inferior appendage-ventral (int. app.-intermediate appendage; lat. pr.-lateral process). 20. $q$ hindwing. 21. a,c, 운 genitalia-lateral, ventral; $b, d$, vaginal apparatus-lateral, ventral (ind.-indentation). 
metathoracic sclerites paler; legs light brown basally, dark apically, with dark borders. Head subcircular (Fig. 36), with area between lateral carinae slightly domed (Fig. $30 \mathrm{~b}$ ), and appearing more wrinkled and less shiny than on other Psilotreta; seta 17 much shorter than seta 15, clear and thin. Pronotum with projection of anterolateral corner short. Mesonotal sclerites with dark marking of posterior ridge extending to posterior inflection, which is represented as a light spot (Fig. 30a). Metanotum (Fig. 36) with anterior sclerite bearing 86-90 setae, posterior bearing 3740 , each lateral bearing 43-50. Abdominal segment VIII bearing 3-4 lateral tubercles on each side. Abdominal gills: dorsal-II 10, III 16, IV $11, \mathrm{~V}$ 7-8, VI 4-5, VII 2; ventral-II 7-9, II1 16-18, IV 8-12, V I1, VI 10, VII 910. Larva up to $11 \mathrm{~mm}$ in length; head up to $1.0 \mathrm{~mm}$ in width across eyes. Larval case up to $12 \mathrm{~mm}$ in length.

\section{HABITAT}

$P$. rossi larvae have been collected from small spring seeps.

\section{DISTRIBUTION (Fig. 39)}

$P$. rossi is known only from the mountains of North Carolina, Virginia, and West Virginia.

\section{MATERIAL EXAMINED AND ADDITIONAL RECORDS}

NORTH CAROLINA-Macon Co.: Coweeta Hydrobiological Lab., 15.vi.1970, holotype oे (fide Wallace, 1970); Cullasaja R. 5 mi. from Highlands on U.S. 64, 18.vi.1976, 1 (GAS); Wayah Bald, 8.vi.1961, 1 o MMT (USNM); sm. spring str. 2.7 mi. from Wayah Bald Rd on For. Serv. Rd 69, 20.v.1970, L (ROM 700363). Transylvania Co.: 4 mi. s. Blue Ridge Pkwy on NC \#215, sm. roadside seepage, \#8, 15.v.1979, 1 ơ (KSBS); same, L PP P, 2 o 1 \& MMT (CLEM). VIRGINIA-Grayson Co.: series of spring-fed strs off Mt Rogers Trail into Lewis Fork, 20.vi.1981, 4 ठ (ROM); spring seep-bog along Forest Rd 89, 13.viii.1979, 1 of 2 क (VPI). Shenandoah Co.: nr Liberty Furnace, Little Sluice Mtn trail, springs, 21.vii.1974, I o; same, 27.x.1974, L (USNM). WEST VIRGINIA-Pocahontas Co.: Right Fork Tea Cr., red spruce forest, small spring with sedge, Monongahela Nat. For., 4.vii.1984, 18 o (USNM); small seep to Hills Cr., Hills Creek Scenic Area, Rt. 39, Monongahela Nat. For., 20.xi. 1982, L (USNM).

\section{Psilotreta amera (Ross)}

Heteroplectron amera Ross, 1939:68, fig. 8. Holotype ơ, allotype $q$ (INHS), Parksville, Tennessee.

Psilotreta amera-Ross, 1944:286, 300, fig. 953A,B.

The adult of this species are distinguished by the very large setal warts on the head of the male, and by the distinctive genitalia of both sexes. The larva is distinguished by the circular domed head.

\section{ADULT}

Forewing $10-11 \mathrm{~mm}$ in length. Antennae $1.2-1.5 \times$ forewing length; scape 3.5-4.I $\times$ pedicel length; first two fused flagellar segments 2.0-2.6 $\times$ pedicel length. Maxillary palpi as in $P$. rossi. Frontoclypeus with median wart large; vertex of female with warts identical to $P$. rufa; vertex of male (Fig. 3) with very small anteromesal warts, anterior pair of warts either absent or fused with posterior pair, and posterior pair greatly enlarged, occupying entire posterior half of head, each one having raised prominence near midline of head thickly covered with erect brown setae and dense pile of erect blackish setae on rest of wart, resulting in distinct two-toned appearance.

Male genitalia (Fig. 22). Segment VII with narrow dorsoventral invagination near posterior edge of pleural membranes. Segment IX with apical segment of inferior appendages small, and bearing one basal and one apical long black curved tooth. Segment X with apexes of dorsomedian process bifid and widely separated (Fig. 22b), extending considerably beyond bases of lateral processes in some specimens (Fig. 22a); lateral processes narrow throughout, sinuate and directed posteroventrally, and ending in sharp points; intermediate appendages short, arcuate but not curled, and ending in sharp ventrally directed points.

Female genitalia (Fig. 23). Segment IX with median plate deeply invaginated at anterolateral corner (Fig. 23a); tergum IX with shallow indentation laterally. Posterior vaginal sclerites narrow, parallel sided, and approximately uniformly separated throughout their length (Fig. 23d).

LARVA (Figs. 31, 37)

Coloration and shape of head similar to $P$. rossi. Head setation and shape of pronotum similar to $P$. rufa. Head strongly domed (Fig. 3lb), subcircular in dorsal aspect (Fig. 37); in lateral aspect, posterodorsal angle of head rounded (Fig. 31a). Metanotum (Fig. 37) with anterior sclerite bearing 60-63 setae, posterior bearing 20-24, each lateral bearing 41-47. Abdominal segment VIII bearing 23 lateral tubercles on each side. Abdominal gills: dorsalII 7. III 15-16, IV 6-9, V 6-7, VI 4-6, VII 3, VIII 2; ventral-II 3-4, III 17, IV 8, V 6, VI 7, VII 7-8. Larva up to $9 \mathrm{~mm}$ in length; head up to $1.1 \mathrm{~mm}$ in width across eyes. Larval case up to $10 \mathrm{~mm}$ in length.

\section{HABITAT}

Like $P$. rossi, $P$. amera larvale apparently inhabit small spring seeps. 


\section{DISTRIBUTION (Fig. 39)}

$P$. amera has the most restricted range known for any North American species, a relatively small area in the vicinity of Great Smoky Mountains National Park: Georgia, North Carolina, South Carolina, Tennessee.

\section{MATERIAL EXAMINED AND ADDITIONAL RECORDS}

GEORGIA-Lumpkin Co., 3 mi. s. Neels Gap, Chestatee Br., 23.v.1946, 1 ㅇ (1NHs). NORTH CAROLINA-Haywood Co., trib. w. fk Pigeon R., 1 mi. s. Sunburst Cpgrd on NC \#215, NC \#6, 15.v.1979, L (ksBs). Macon Co., Nantahala Nat. For, Cullasaja R. nr U.S. 64 at entr. Cliffside L. Rec. Area, 17.v.1979, P (KsBS). Swain Co., Great Smoky Mtns Nat. Pk, Smokemont Cpgrd and nearby, 11-14.v.1970, PP P (USNM). SOUTH CAROLINA-Oconee Co.: Sumter Nat. For., str. in Yellow Br. Picnic Area, ca $1500 \mathrm{ft}, 19 . \mathrm{v} .1970,3$ \% MMT 3 q MMT (ROM 700356); 5 mi. nw. Tamasee, sm. spr. brook above Wash Br. of Townes Cr., 26.v. 1980, 2 đ; same, 23.vi. 1980, 7 ơ (CLEM); 6 mi. s. Walhalla, Crane Cr., U.S.
Fish Hatchery n. Tamasee, 26-27.v.1980, $1 \delta$ (CLEM). Pickens Co., $9 \mathrm{~km}$ nw. Clemson, Wildcat Cr., 1819.v.1979, 1 ơ; same, 30.ix.1961, P (CLEM). TENNESSEE-Blount Co.: Tenn. \#73 ca $3 \mathrm{mi}$. w. fk Little Rat, trib. to Laurel Br. on Cadestone Rd, 11.iv. 1981, PP P (GAS); Great Smoky Mtns Nat. Pk, trib. to Little R. 0.5 mi. above fk, 4.v.1981, P (UT); Spicewood Br., trib. w. prong Little R., 11.iv.1981, PP (GAs); same, 4.v.1981, P (UT). Cocke Co., English Cr. at Carson's Spring nr Newport, 38.vi.1946, 1 đ̛ (1NHS). Great Smoky Mtns Nat. Pk, 1978, 1 ơ (UT). Knox Co., 1.v.1963, q MMT (CLEM). Polk Co.: first rock-face str. below Coker $\mathrm{Cr}$., 5-200 $\mathrm{m}$ above Hiwassee R., 12.v.1977, L PP P, ơ and 9 MMT (UT); streams between Coker Cr. and Lars Cr. at Hiwassee R., 8.iv.1977, PP (UT); trib. Hiwassee R. 2.6 mi. from Hwy 411, Quinn Springs For. Serv. Cpgrd, L PP P, $\delta$ and $q$ MMT (UT); Parksville, 25.iv. 1938, holotype ơ, allotype \&, paratype ơ (fide Ross, 1939). Sevier Co.: Great Smoky Mtns Nat. Pk, Jakes Br. nr Elkmont Cpgrd, 10.iv.1981, PP (GAS); e. slope Webb Mtn, George Cox property, 17.iv17.v.1975, 1 ठै (UT). 


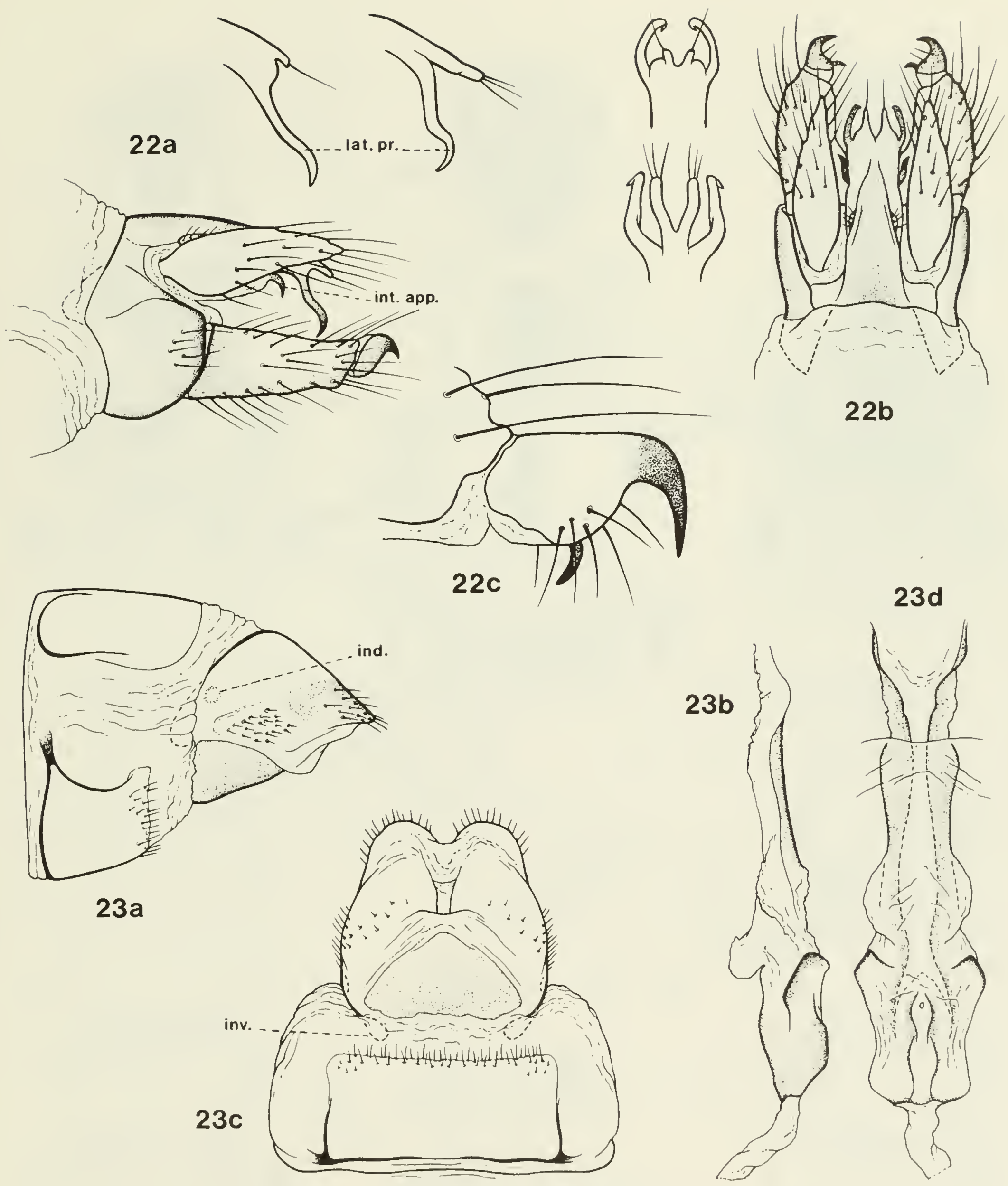

Figs. 22, 23. Psilotreta amera. 22. $a, b, \delta$ genitalia-lateral, dorsal (with detail of variations of median dorsal and lateral processes of segment X); c, apical segment of inferior appendage-ventral (int. app.intermediate appendage; lat. pr.—lateral process). $23 . a, c, q$ genitalia-lateral, ventral; $b, d$, vaginal apparatus-lateral, ventral (ind.-indentation; inv._invagination). 

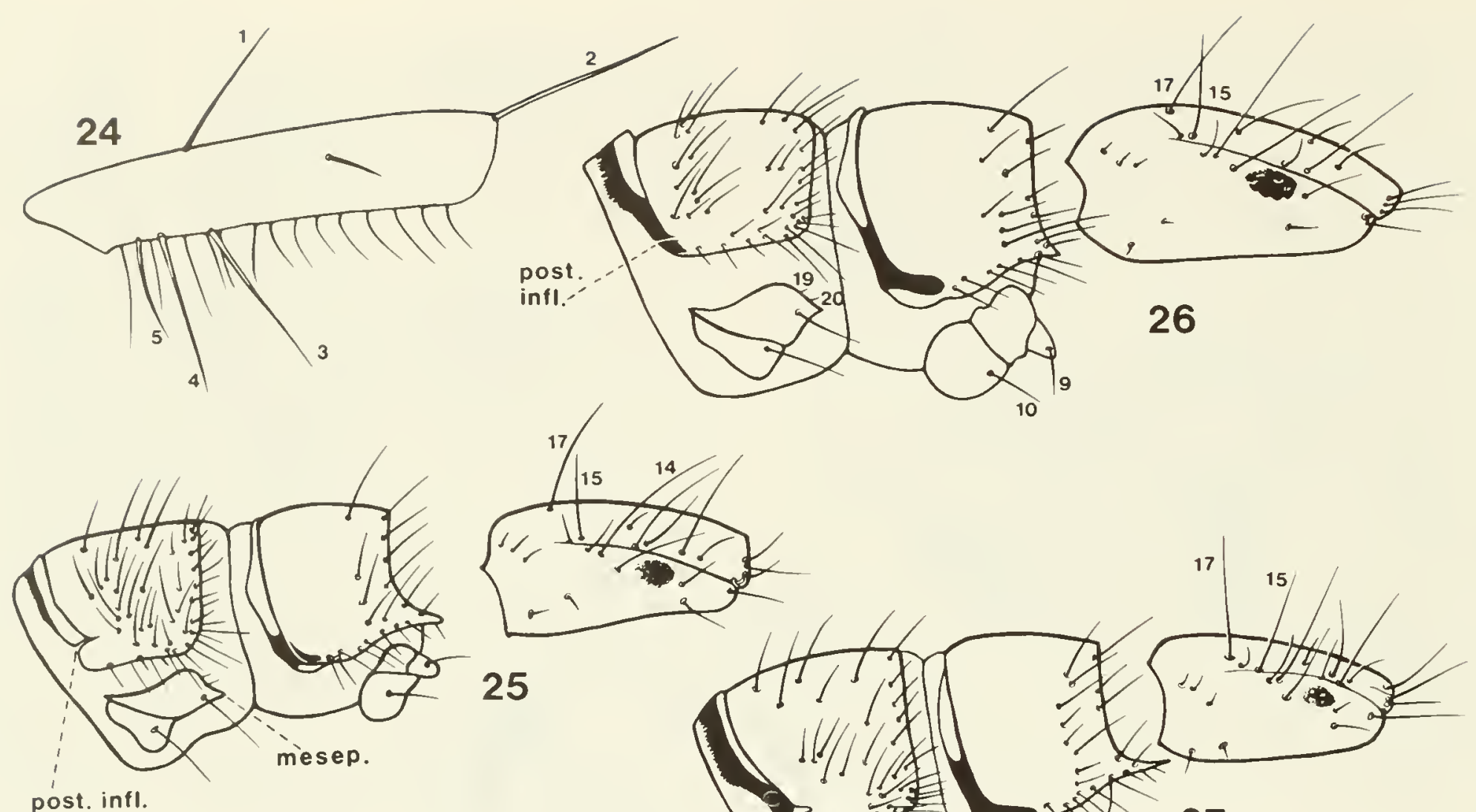

oost mint
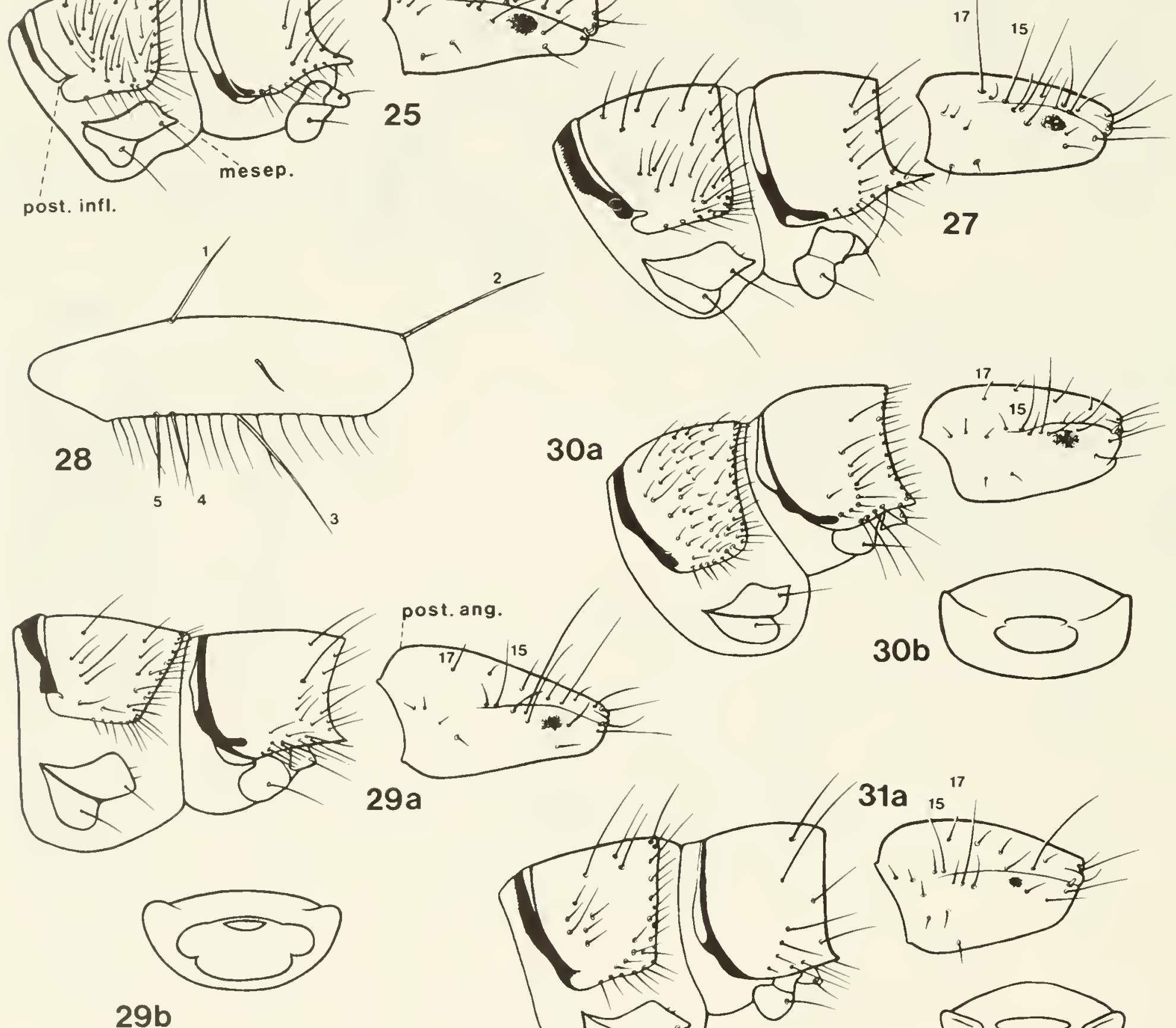

$29 a$
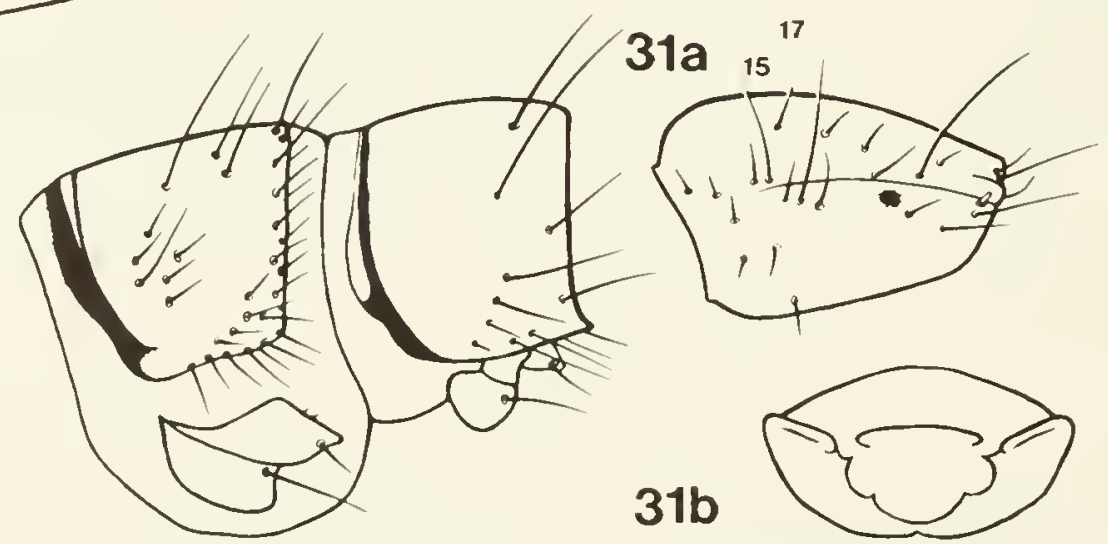

Figs. 24-31. Larvae of Psilotreta spp. 24, 28. Left mesofemur-anterior. 25-27. Head, prothorax, and mesothorax-lateral. 29-31. Head, prothorax, and mesothorax-lateral (detail of head in frontal aspect). (Abbreviations: mesep.-mesepisternum, anteroventral angle; post. ang.-posterior angle of head; post. infl.-posterior inflection.) 24, 25. P. indecisa. 26. P. frontalis. 27. P. labida. 28, 29. P. rufa. 30. P. rossi. 31. P. amera. 

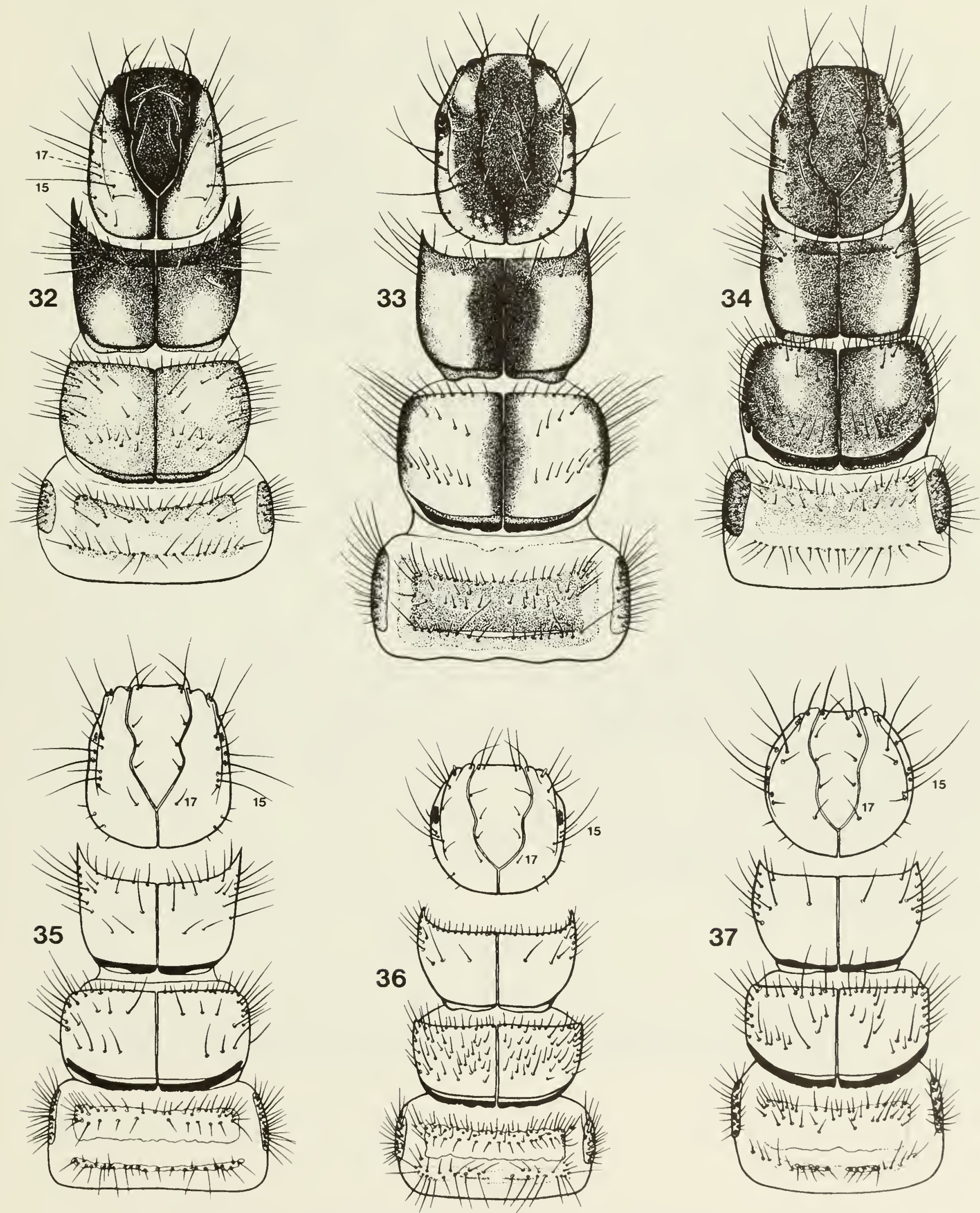

Figs. 32-37. Larvac of Psilotreta spp., head and thorax-dorsal. 32. P. indecisa. 33. P. fromalis, 34. P. labida. 35. P. rufa. 36. P. rossi. 37. P. amera. 


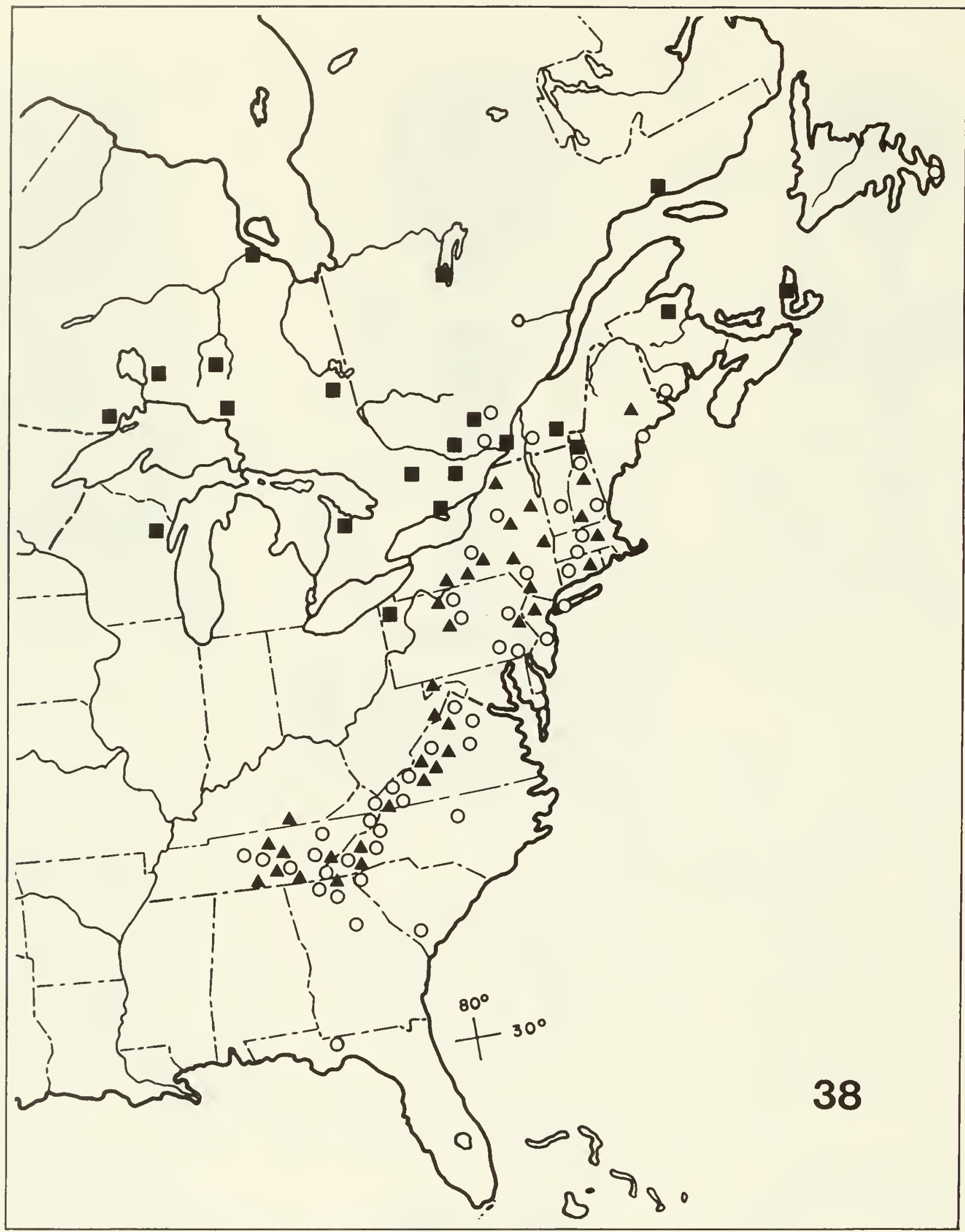

FIG. 38. Distribution of Psilotreta spp.: $P$. indecisa-squares; $P$. frontalis-circles; $P$. labida-triangles. 


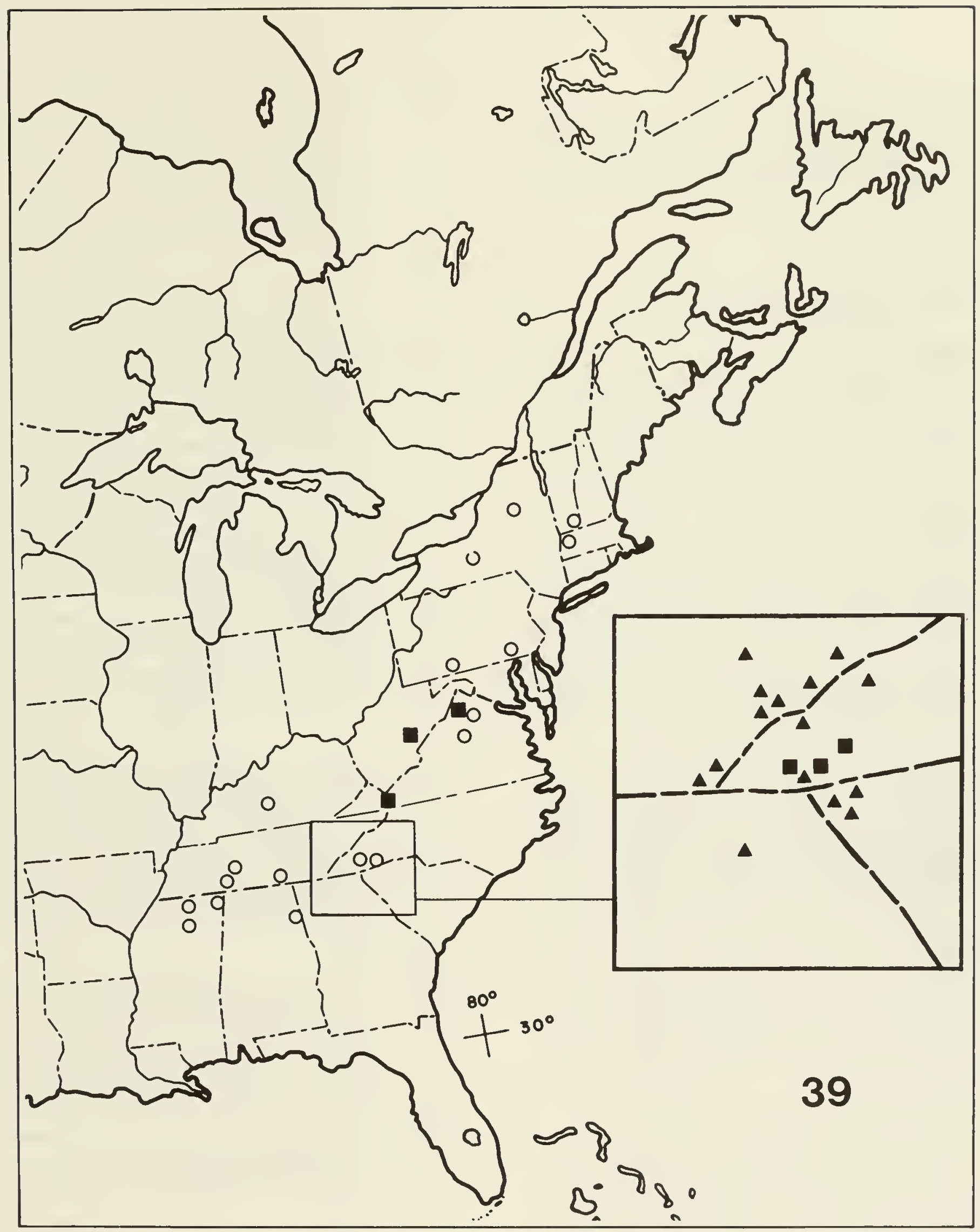

FIG. 39. Distribution of Psilotreta spp.: P. rufa-circles; $P$. rossi-squares; $P$. amera-triangles. 
The 14 species of Psilotreta now known from Asia are a heterogeneous assemblage. We have examined males of 10 species, females of 6 , and larvae of 3 , and offer a key to the males; females and larvae are insufficiently known to provide keys.

\section{Key to Males of Asian Psilotreta}

$3\left(I^{\prime}\right) \quad$ Segment $X$ with median dorsal process completely fused to lateral processes, forming hood over intermediate appendages and lateral processes; intermediate appendages straight, slender, directed anteroventrad (Schmid, 1959, pl. IV, fig. 8)............ quadrata, p. 40 $3^{\prime} \quad$ Segment $X$ with median dorsal process free of lateral processes (Fig. 46a), or if fused not forming a hood (Fig. 48a); intermediate appendages of different shapes but not slender, straight, or directed anteroventrad .......4

4(3') Segment $X$ with preanal appendages short, median dorsal process fused with lateral processes; lateral processes each with a projection arising from anteroventral corner, with a distinct dorsal lobe and a prominent horn curved posteroventrally, and ending in a sharp point; intermediate appendages arising beneath lateral processes, curving dorsally around anteroventral projections of lateral processes, and each tapering to a sharp point which is directed ventrolaterally close to apex of each lateral process (Fig. 48)...........chinensis, p. 34 $4^{\prime} \quad$ Segment $X$ with preanal appendages long and foliose in lateral aspect (Fig. 46a), median dorsal process free of lateral processes, and lateral processes not as above ............5

5(4') Inferior appendages each with apical segment foot shaped in dorsal aspect (Mosely, 1942, fig. 8 ), or at least with a prominent lobe along outer margin (Hwang, 1957, fig. 94)..........6

5' Inferior appendages each with apical segment not foot shaped, and without lobes (Figs. 51a, 53a) ....................... . . .

6(5) Intermediate appendages curved, each tapering to a point directed ventrolaterally; lateral processes each with a recurved anteroventral projection, tapered and pointed (Hwang, 1957, fig. 93); wings lacking discal cell (Hwang, 1957, fig. 92) ............... orientalis, p. 50

6' Intermediate appendages much as above, but each with a dorsal accessory hook (Mosely, 1942, fig. 7); lateral processes apparently lacking; wings with discal cell (Mosely, 1942, fig. 6) ...................... . . 50 
7(5') Segment $X$ having lateral processes bean shaped in lateral aspect and without projections; inferior appendages each with basal segment bearing a small apicoventral process (Botoşăneanu, 1970, pls. XXXVl-XXXVIII) .....8

$7^{\prime} \quad$ Segment $X$ having lateral processes of various shapes and with (Fig. 46a) or without (Fig. 53a) projections; inferior appendages each with basal segment lacking apicoventral process (Fig. 5la.c) ..................10

8(7) Segment $X$ in dorsal aspect with median dorsal process narrow and pointed apically; intermediate appendages long and narrow, each with a subapical spine; phallotheca with ventral surface strongly sclerotized to apex; parameres long, narrow, and pointed (Botoşăneanu, 1970, pl. XXXVI)..............kisoensis, p. 35

$8^{\prime} \quad$ Segment $X$ in dorsal aspect with median dorsal process more robust and apex expanded and bilobed; intermediate appendages either long and narrow or more robust but without a subapical spine; phallotheca with ventral surface membranous to apex; parameres as above or short and blunt (Botoşăneanu, 1970, pls. XXXVII, XXXVIII) ..............99

9(8') Parameres short and blunt, strongly decurved ventrally; inferior appendages each with apicoventral projection of basal segment prominent; head with frontoclypeal wart large and bearing numerous long, erect setae; vertex with a deep groove along coronal sulcus (Botoşăneanu, 1970, pl. XXXVII)......... falcula, p. 40

9' Parameres long, pointed, and only slightly decurved apically; inferior appendages each with apicoventral projection of basal segment weakly developed, not prominent; head with frontoclypeal warts paired, small, and bearing normal setae; vertex without groove (Botoşăneanu, 1970, pl. XXXVIII)

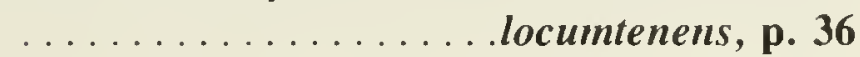

$10\left(7^{\prime}\right) \quad$ Phallus with parameres long, slender, and acute (Fig. 53d,e) ..................11
10' Phallus with parameres variously formed, not long, slender, and acute (Figs. 46d,e; 5ld,e)

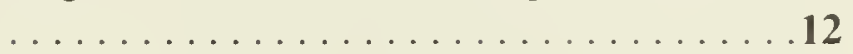

11(10) Segment $X$ with lateral processes each having an acute ventral projection, and intermediate appendages each having two acute, curved projections, so that three distinct acute projections are visible in lateral aspect (Schmid, 1965, pl. VII, fig. 9) ............trispinosa, p. 47

11' Segment $X$ with lateral processes each reduced to inconspicuous low ridge (Fig. 53a) ....... $\ldots \ldots \ldots \ldots \ldots$ assamensis, p. 41

12(10') Segment $X$ with intermediate appendages both broad and bifid apically in lateral aspect (Kimmins, 1964, fig. 40); median dorsal process a short cordate lobe in dorsal aspect (Kimmins, 1964, fig. 41) ........... quinlani, p. 50

12' Segment $X$ with intermediate appendages small and simple (Fig. 46a); median dorsal process elongate, bifid, or truncate apically, not cordate (Fig. 46b) .................... 13

13(12') Inferior appendages uniformly cylindrical in lateral aspect (Fig. 46a) and each with a low, rounded median lobe in ventral aspect (Fig. $46 c$ ); segment $X$ with lateral processes each having a narrow, acute projection directed posteriorly; intermediate appendages short and pointed ventrad (Fig. 46a); phallus without pair of accessory processes above parameres; parameres narrow in lateral aspect (Fig. 46d,e) japonica, p. 34

13' Inferior appendages each with a ventral projection in lateral aspect (Fig. 5la) and with a prominent, angulate basomedian lobe in ventral aspect (Fig. 51c); segment $X$ with lateral processes each having a relatively broad, rounded projection directed posteriorly; intermediate appendages a pair of small, low inconspicuous lobes (Fig. 5la); phallus with a pair of small accessory appendages situated dorsad of the large, broad parameres (Fig. 51d,e) ........ 


\section{Psilotreta japonica (Banks)}

Odontocerum japonicum Banks, 1906:110. Holotype $q$ (MCZ, Type 11837), Gifu, Japan.

Odontocerum japonicum-Ulmer, 1907a:5I-52, figs. 7679 .

Psilotreta japonica-Ulmer, 1907b:126, figs. 157, 158.

Psilotreta kyotoensis Iwata, 1928:118, 124-125, figs. 213,

214. Synonymy by Tsuda (1942b).

Psilotreta japonica-Tsuda, 1959:143, fig. 256.

This species is most similar to $P$. schmidi sp. nov., from which it is distinguished by the narrow, acute lateral processes, the small, acute, and projecting intermediate appendages of segment $X$, and the less prominent development of the ventromesal angle of the basal segment of the inferior appendages.

\section{ADULT}

Forewing $10-11 \mathrm{~mm}$ in length. Coloration black dorsally; legs and palpi dark brown; forewings brown with faint irroration. Each wing with discal cell long and widest at origin of vein $R_{2}$, with $R_{2}$ kinked at junction of crossvein $r$, and lacking scales. Scape subequal in length to head. Maxillary palpi broken on males examined, first three segments cylindrical and unmodified, second segment shortest and third longest; on females, first three segments similar, segments four and five subequal, each slightly longer than segment three. Labial palpi in both sexes with each segment slightly longer than preceding segment, last segment thinner than the first two. Setal warts of vertex similar to those of $P$. indecisa, anterior warts close to antennal sockets, posterior warts ovoid.

Male genitalia (Fig. 46). Segment VIl with pleural membranes each bearing a small lobe posteriorly. Segment IX typical for genus; dorsolateral piece extremely narrow, dorsum slightly longer than wide and produced laterally into thin ledge, which overhangs base of segment $\mathrm{X}$ and obscures circular basal setal warts in dorsal aspect; basal segment of inferior appendage dark in basal fourth and lacking setae, the remainder light, with low, broad median basal lobe, and with numerous long setae, which are subcylindrical and slightly tapered; apical segment dark and setose, slightly tapered in lateral aspect, obliquely truncate in ventral aspect, and with numerous small black spines apically. Segment $X$ with median dorsal process large, apex flared, bifid, and bearing several setae, and in lateral aspect deeply excavate basodorsally; lateral processes long, acute, posteriorly directed, arising from posterior edge of body of segment $\mathrm{X}$; intermediate appendages short, stout, pointed, darkly sclerotized, arising beneath bases of lateral processes, directed ventrolaterad, and curved slightly caudad; preanal appendages broad, foli- aceous, broadest in basal fourth and tapering apically, extending almost to apex of segment $X$, with numerous long setae apically and ventrally.

Phallus with two parameres arising close together on venter of endotheca, rounded apically in lateral aspect, pointed in ventral aspect; aedeagus long with sclerotized ventral plate.

Female genitalia (Fig. 47). Females of $P$. japonica are distinguished from those of $P$. kwantungensis by a median sulcus in the posterior portion of sternum IX, from $P$. chinensis by lack of a lateral depression in the tergum of segment IX and by the anterior vaginal sclerites being shorter than the posterior, from $P$. falcula and $P$. locumtenens by the setal warts of the tergum of segment IX being produced only slightly, and from $P$. assamensis sp. nov. by details of the shape and orientation of the vaginal sclerites. General structure similar to North American species. Apex of segment $X$ in lateral aspect angular. Posterior portion of sternum IX with distinct longitudinal median sulcus. Vaginal chamber with anterior and posterior portions approximately equal in length; sclerites of posterior portion convoluted in lateral aspect, broad and widely separated in ventral aspect; anterior portion with apical corners produced as rounded lobes.

\section{LARVA}

The larva of $P$. japonica was described as $P$. kyotoensis (Iwata, 1928), a name later synonymized with $P$. japonica (Tsuda, 1942b). We have seen no specimens.

\section{MATERIAL EXAMINED}

JAPAN. Gifu, holotype $q$, paratype $q$ (MCZ). Kyoto, 8.v.1953, I ơ (P. W. Oman) (USNM).

\section{NOTE}

When Banks described $P$. japonica, he indicated that he had two specimens, but no holotype was designated at the time. His material, which we have examined, consists of the two females listed above, one of which now bears a red MCZ type label (11837), presumably affixed by Banks himself at some time after publication of the description.

\section{Psilotreta chinensis Banks}

Psilotreta chinensis Banks, 1940:219-220, pl. 27, fig. I; pl. 30, figs. 67, 68, 70. Holotype of (USNM, Type 53194), China, Szechwan near Washan, 1220-1830 m, vii.

The male of $P$. chinensis is distinguished from all others in the genus by the absence of the discal cell of the forewing, $\mathrm{R}_{2+3}$ being fused with $\mathrm{R}_{3+4}$ for most of their lengths, and 
by the preanal appendages being very short. The forewing of the male of $P$. orientalis also appears either to lack the discal cell or at least to have the discal cell open apically, but the preanal appendages are long.

\section{ADULT}

Forewing $12 \mathrm{~mm}$ in length in male, $15 \mathrm{~mm}$ in female. Coloration light brown in male, darker in female. Although Banks described $P$. chinensis as having venation similar to $P$. japonica, with a discal cell, the male lacks a discal cell (Fig. 52). Stem of $\mathrm{R}_{3+4+5}$ fused throughout length to anastomosis; $R_{2}$ arising about halfway between origins of $R_{1}$ and $R_{3}$ and kinked at crossvein $r ; R_{4}$ and $R_{5}$ stalked; a narrow fold of membrane overlapping $R_{3+4+5}$ dorsally from behind, this vein bearing numerous stiff setae ventrally; forewings covered with setae intermingled ventrally with scattered scales. Forewing of female with a long, narrow discal cell; $\mathrm{R}_{2}$ arising in basal fourth and kinked at crossvein $r$. Hindwings of both sexes each with long discal cell; $\mathrm{R}_{2}$ arising in basal fourth. Maxillary palpi in both sexes with each segment slightly longer than the preceding and heavily setose, male with scattered scales on basal segments. Labial palpi having first segment short, second and third segments longer and subequal, and long setae. Face of male with elongate lateral setal warts next to eyes having long setae and short scales; frontoclypeus with a narrow scale-filled indentation extending dorsally between antennae and continuous on vertex (Fig. 50); on vertex anteromedian pair of warts on raised surfaces on either side of indentation, anterior pair ovate, and posterior pair large and transverse, widest laterally and narrowing medially. Female lacking indentation and scales, but otherwise similar to male. Pronotum of male with scales intermingled among long, silky setae; female lacking scales on pronotum.

Male genitalia (Fig. 48). Segment IX typical for genus; longer in ventral half, with narrow, subtriangular posteromedian lobe dorsally and low anterior lobe laterally; inferior appendages long; basal segment extending beyond lateral process and cylindrical with many setae; apical segment approximately one-third length of basal segment, cylindrical, and truncate apically with numerous small black teeth and short setae. Segment $X$ with basal setal wart circular, distinct; median dorsal process short, projecting only slightly posterad of segment IX, bifid apically, and completely fused to lateral processes; lateral processes each with large anteroventral projection bearing long, decurved, tapered spine ventrally and short blunt projection dorsally; intermediate appendages arising on body of segment $X$, each beneath anterolateral projection of lateral process, extending as large spine curving posterodorsally above lateral process, and ending in sharp ventrally directed point; in lateral aspect intermediate appendage and spine of lateral process nearly forming circle with points meeting posteriorly; preanal appendages short, ovate, and bearing numerous setae.

Phallus with phallotheca long, narrow, and cylindrical; endotheca short, with pair of long, sharply pointed parameres arising ventrolaterally and extending two-thirds length of aedeagus; aedeagus large, membranous, in ventral aspect roughly triangular with two pairs of lobes laterally and single lobe posteromedially, and in lateral aspect with phallotremal sclerite forming bilobed projection dorsally.

Female genitalia (Fig. 49). The female of $P$. chinensis is distinguished from the others we have examined by the tergum of segment IX, which has a broad depression laterally, and by the vaginal chamber, on which the anterior portion is clearly longer than the posterior portion and the sclerites of the posterior portion are weak and indistinct. Segment IX with broad, shallow depression laterally; posterior portion of sternum IX with obvious median longitudinal sulcus, apex of each half produced posteriorly. Segment $X$ with apex rounded in lateral aspect. Vaginal chamber with anterior portion longer than posterior portion, anterolateral corners produced laterad, and posterior portion having weak and indistinct internal sclerites.

\section{LARVA}

Unknown.

\section{MATERIAL EXAMINED}

CHINA-Szechwan, near Washan, 4000-6000 ft, vii, holotype $\delta$, paratype + (USNM); paratypes 1 o 3 을 (MCZ). Szechwan, Long Ch'i, 17-18.vii.1938, 1 ठ (USNM).

\section{Psilotreta kisoensis Iwata}

Psilotreta kisoensis Iwata, 1928:117, 124-125, figs. 211, 212.

Psilotreta armata Martynov, 1933:144-145, figs. 7-10.

Psilotreta kisoensis-Uéno, 1935:84-85, fig. 59.

Psilotreta kisoensis-Tsuda, 1942a:285 (P. armata Martynov as synonym).

Psilotreta kisoensis-Tsuda, 1959:143, fig. 255.

Psilotreta kisoensis-Botoşăneanu, 1970:313-316, pl. 36. figs. $1-4$.

This species originally was based on larvae and on adults subsequently described as $P$. armata by Martynov (1933), which later was reduced to synonymy with $P$. Kisoensis by Tsuda (1942a). Botoşăneanu (1970) has provided excellent illustrations of the adults and at the same time described two closely related species, $P$. locumtenens and $P$. falcula. We have examined two males of $P$. kisoensis from Japan. 


\section{ADULT}

The male of $P$. kisoensis is easily distinguished from those of $P$. locumtenens and $P$. falcula by the characters given in the key. To published descriptions we add the following observations: head unmodified, warts on frontoclypeus not enlarged and not bearing abundant long erect setae, vertex without groove.

We did not have access to female specimens, but Botoşăneanu (1970) has illustrated the vaginal sclerites.

\section{LARVA (Figs. 40-42)}

The larva of $P$. kisoensis has been described several times since its original description. Botoşăneanu (1970) has suggested that descriptions by Lepneva (1958, 1966) may apply to $P$. locumtenens or $P$. falcula rather than to $P$. kisoensis. We have examined larvae in the ROM collection from Japan that may be $P$. kisoensis, and we have examined larvae from North Korea sent to us by Dr Botoşăneanu that we believe to be $P$. locumtenens on the basis of a female metamorphotype. The larvae from Japan and North Korea differ slightly but significantly in colour pattern, and we concur with Botoşăneanu that the larva described by Lepneva is more likely to be $P$. locumtenens than $P$. kisoensis. Although the associations are not firm, especially that for $P$. kisoensis, we treat the larvae tentatively under these names.

The larvae of $P$. kisoensis and $P$. locumtenens are similar in morphology and have been adequately described and figured by Lepneva (1958, 1966). We describe here only those features of colour pattern and setation that differ between the two forms or that our study of the Nearctic species has indicated are useful in distinguishing larvae.

Head similar to $P$. locumtenens (see Lepneva, 1966, fig. 677 -note that the setae are mislabelled in fig. 677 , the seta labelled 15 is actually 13 , and that labelled 16 is 15 ; seta 16 is not illustrated, but is extremely fine, clear, and recumbent, positioned near the base of 15 and directed towards 17). Thorax with dark areas diffuse, much less distinct than in $P$. locumtenens, and spread over a wide area of the nota as blotches rather than stripes. Legs darker in most specimens of $P$. kisoensis than in $P$. locumtenens.

Head longer than wide, narrowest anteriorly, not domed dorsally; seta 17 dark brown and slightly shorter and thicker than seta 15. Mesofemur (Fig. 42) with seta 3 situated distad of dorsal seta 1 by approximately the distance between setae 4 and 5. Segment VIII with 12-17 tubercles laterally. Abdominal gills: dorsal-II 12-16, III 16-19, IV 13-15, V 11-16, VI 7-9, VII 4-6; lateral-III 3-4; ventral-II 7-12, III 16-18, IV 12-20, V 10-15, VI 8-14, VII 8-14, VIII 0-6. Larva up to $11 \mathrm{~mm}$ in length; head up to $1.1 \mathrm{~mm}$ in width across eyes. Larval case typical for genus, up to $15 \mathrm{~mm}$ in length.

\section{MATERIAL EXAMINED}

JAPAN-Fukuoka Prefecture: Wakamatsu, 27.vii. 1952, I o (CNC); Sendai, 3.v. 1952, I o (CNC). Nara Prefecture: Yoshino-Kumano Nat. Pk, str. crossing rd $0.3 \mathrm{~km}$ above Mameo, 23.iii.1977, L PP (preserved 19.v.1977) (ROM 770029); Omata River $5.5 \mathrm{~km}$ upstr. Omata, large sidepool, 20.iii. 1977, L (ROM 770023).

\section{NOTE}

Tsuda (1942a) synonymized $P$. armata Martynov, 1933 , under $P$. kisoensis Iwata, 1928. However, Martynov's illustrations of the male genitalia of $P$. armata do not show any indication of the large intermediate appendages found in $P$. kisoensis, which should be visible in the dorsal aspect, at least; nor is any mention made of intermediate appendages in the accompanying description, which is complete in most other aspects, including the description of the pleural abdominal lobes of segment VIl. It will be necessary to restudy the type of $P$. armata to determine its status.

\section{Psilotreta locumtenens Botoşăneanu}

Psilotreta locumtenens Botoşăneanu, 1970:313-314, pl. 38, figs. 1-5; pl. 39, fig. 2, ơ ․ Holotype ô (Zoological Institute, Polish Academy of Sciences, Warsaw), North Korea, Hamgjong-pukto Province, River Porochon about $2 \mathrm{~km}$ northwest of Kjong-song, 4.vi.1965.

This species is most closely related to $P$. falcula and $P$. kisoensis. We have examined uncleared male and female paratypes, a female metamorphotype, pupae, and larvae.

\section{ADULT}

The male can be distinguished by characters given in the key. To the original description we add the following observations: head unmodified; frontoclypeus with a pair of small discrete setal warts on either side of median groove, these warts bearing long setae; vertex without a groove, with anteromesal and anterior warts absent and with posterior warts small, rounded, and separated mesally by approximately twice the diameter of one wart.

The females may be distinguished from all other species except $P$. falcula (and $P$. kisoensis?) by the elongation of the setal wart of the tergum of segment $X$, and from all species by details of the vaginal sclerites (see Botoşăneanu 1970, pl. 39, fig. 2). To the original description we add the following observation: tergum of segment $X$ with setal warts elongated posteriorly on either side as fingerlike processes. 

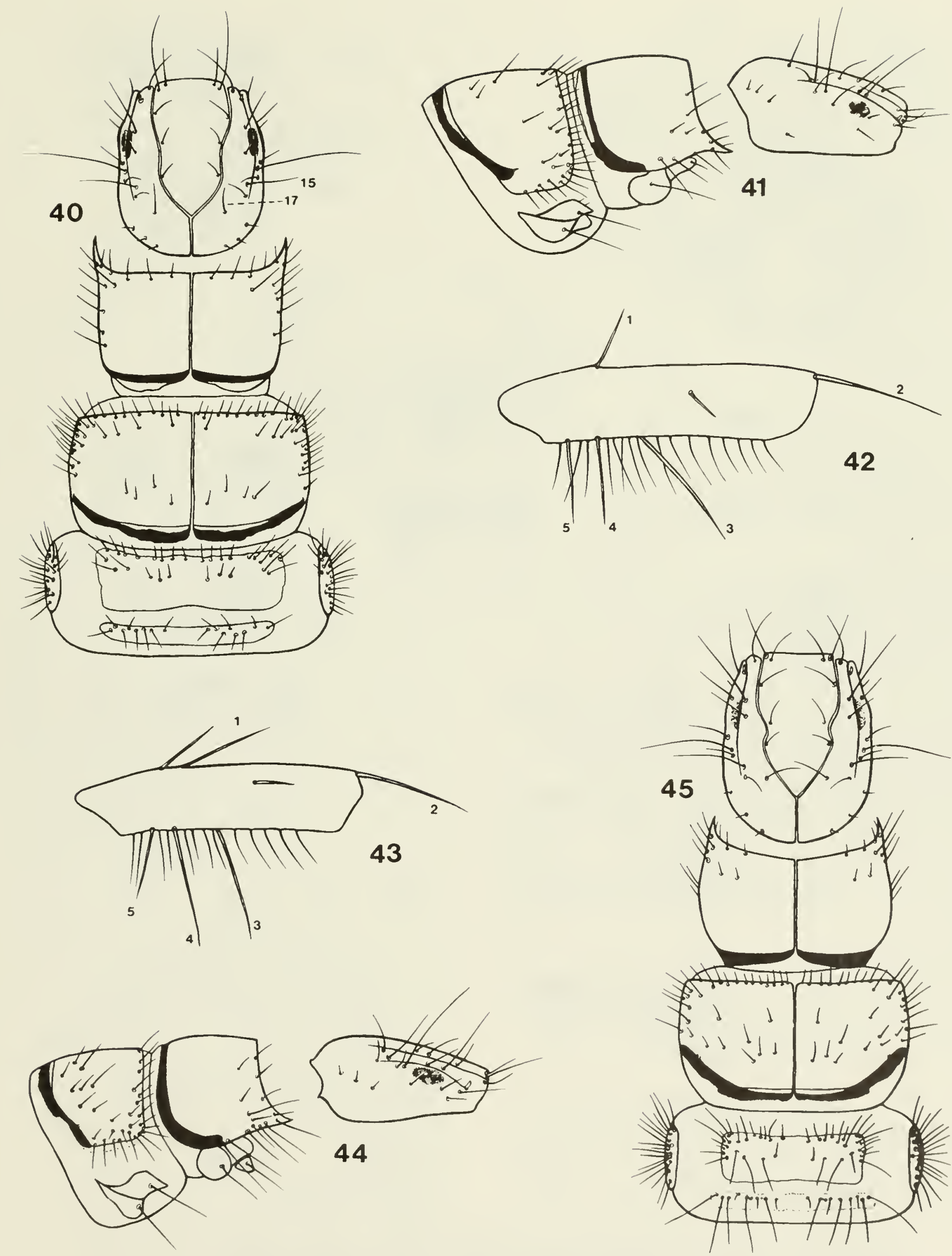

Figs. 40-45. Larvac of Psilotreta spp. 40, 45. Head and thorax-dorsal. 41, 44. Head, prothorax, and mesothorax-lateral. 42, 43. Left mesofemur-anterior. 40-42. P. kisoensis. 43-45. Psilotreta sp. (India, Assam, Kameng). 

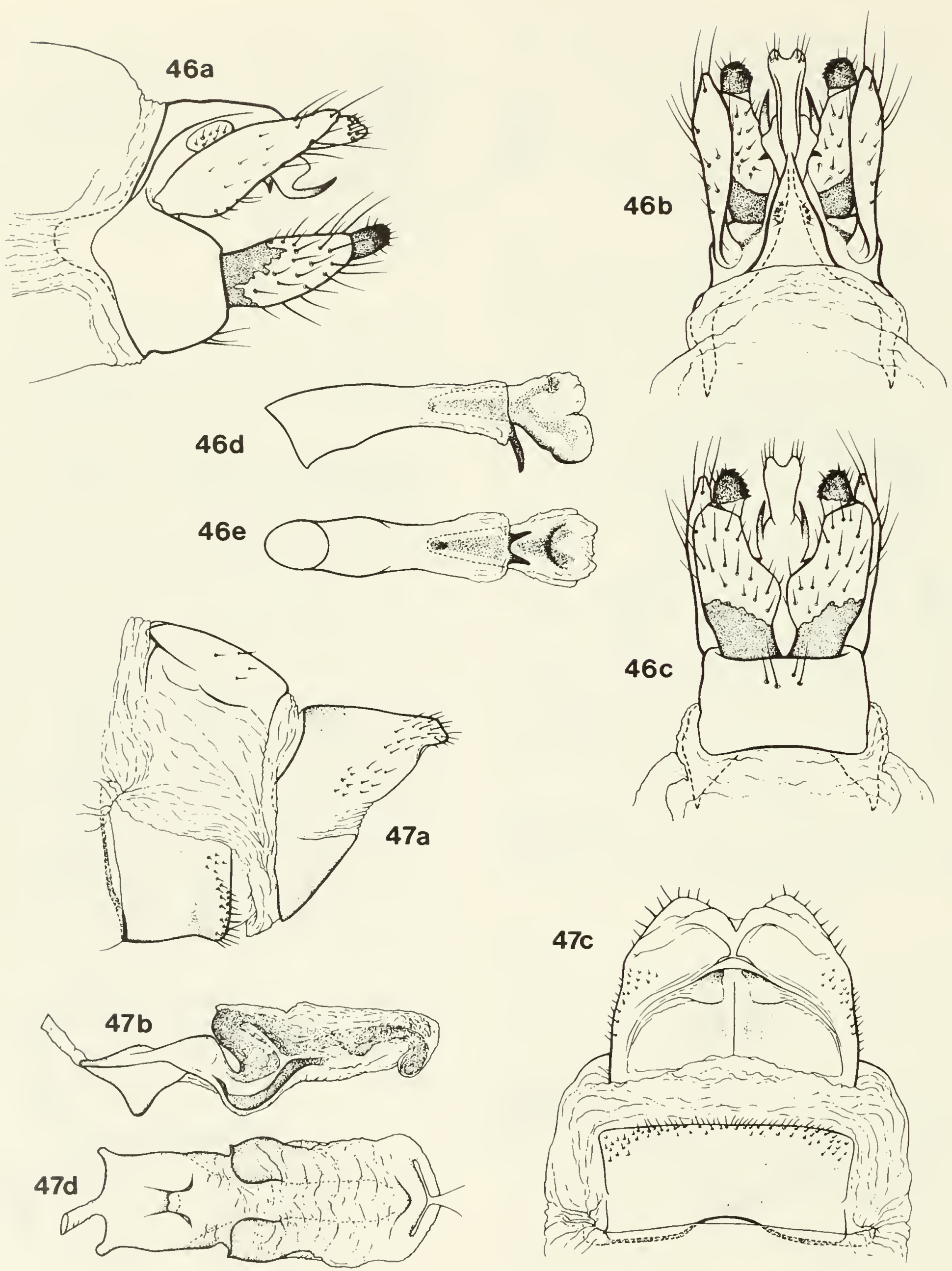

Figs. 46, 47. Psilotreta japonica. 46. $a-c, \delta$ genitalia-lateral, dorsal, ventral; d,e, phallus-lateral, ventral. 47. $a, c$, genitalia-lateral, ventral; $b, d$, vaginal apparatus-lateral, ventral. 


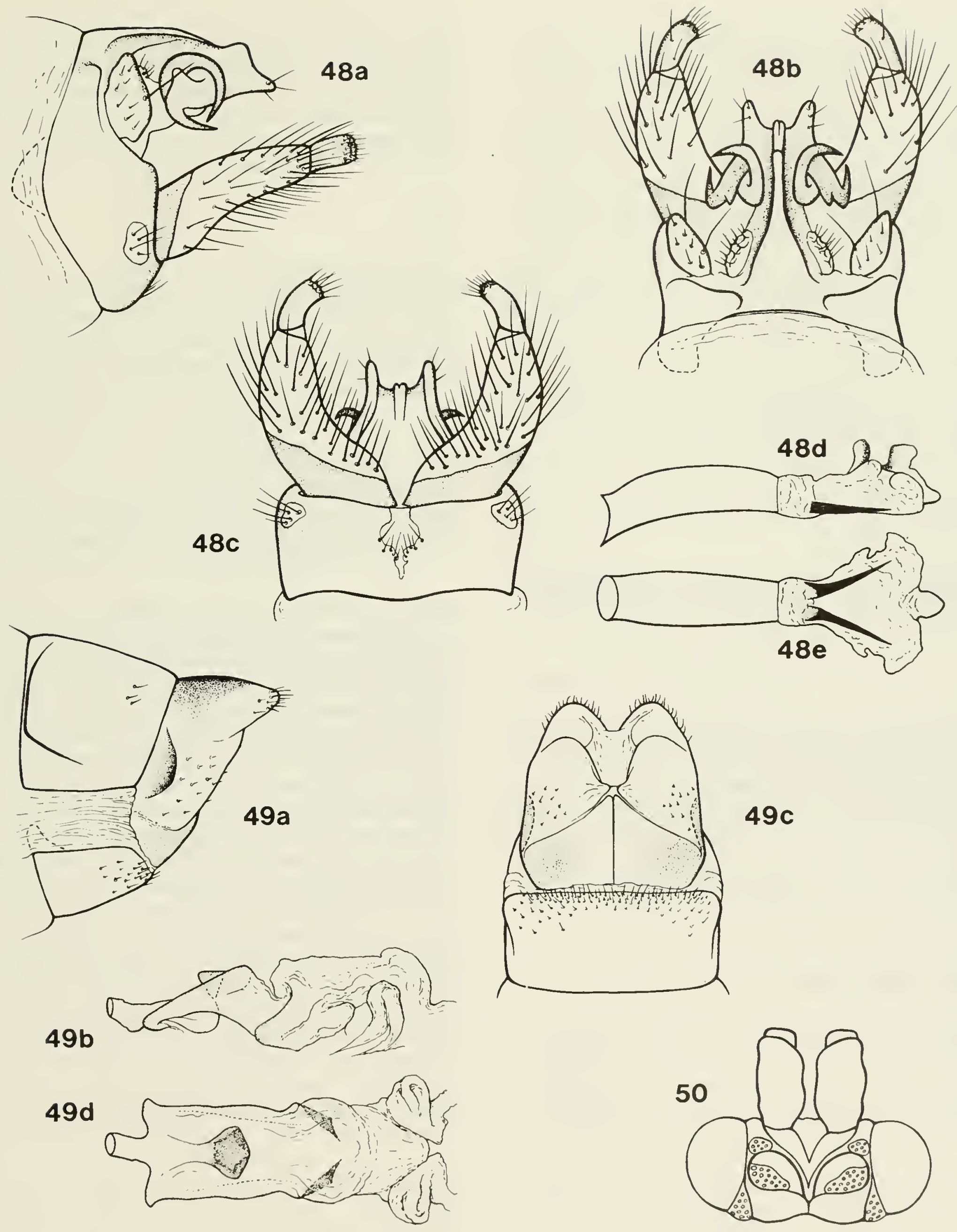

Figs. 48-50. Psilotreta chinensis. 48. $a-c$, of genitalia-lateral, dorsal, ventral; d,e, phallus-lateral, ventral. 49. $a, c$, q genitalia-lateral, ventral; $b, d$, vaginal apparatus-lateral, ventral. 50 . $\delta$ head-dorsal. 


\section{LARVA}

This species may be the one described by Lepneva (1958, 1966) under the name $P$. kisoensis, as discussed above. To the description in those works we add the following observations: colour pattern discrete dark brown streaks on a yellowish background, as opposed to the more diffuse blotches of $P$. kisoensis larvae. Head longer than wide, not domed dorsally; head seta 17 brown, shorter than seta 15 . Mesofemur with seta 3 situated distad of dorsal seta I by approximately the distance between setae 4 and 5 . Metanotum with anterior sclerite bearing $35-40$ setae, posterior bearing 18-23, each lateral bearing 35-40. Segment VIII with 8-9 tubercles laterally. Abdominal gills: dorsal-II 15-18, III 21-24, IV 15-19, V 13-18, VI 8-9, V1I 5-7; ventral-II 10-11, III 15-17, IV 16-17, V 14-15, VI 1217, VII 11-14. Larva up to $13 \mathrm{~mm}$ in length; head up to 1.2 $\mathrm{mm}$ in width. Larval case typical for genus, up to $16 \mathrm{~mm}$ in length.

PUPA

Typical for genus. Case up to $19 \mathrm{~mm}$ in length.

\section{MATERIAL EXAMINED}

NORTH KOREA-Hjangsan District, Mjohjang-san: 1622.vi.1965, ơ + paratypes (LB); Sangvon-am, 17.vi. 1965, L PP P, \& MMT (ROM).

\section{NOTES}

The association is based on a female metamorphotype which is identical with the illustration of $P$. locumtenens in Botoşăneanu (1970), and on three pupae, one prepupa, and eight early fifth instar larvae. This collection is from Botoşăneanu's Station 14, which is one of the paratype localities of $P$. falcula. However, the type locality of $P$. locumtenens (Station 17) apparently is nearby in the same river system.

\section{Psilotreta falcula Botoşăneanu}

Psilotreta falcula Botoşăneanu, 1970:314-316, pl. 37, figs. 1-5; pl. 39, fig. 3, ठ o . Holotype đे (Zoological Institute, Polish Academy of Sciences, Warsaw), North Korea, Hamgjong-pukto Province, Poro-chon River about $2 \mathrm{~km}$ northwest of Kjong-song, 4.vi. 1965.

This species is closely related to $P$. kisoensis and $P$. locumienens and can be distinguished by details of the genitalia and the structure of the head of the male, as outlined in the key, and by details of the vaginal sclerites and the setal wart of the tergum of segment $\mathrm{X}$ of the female. We have examined uncleared male and female paratypes.

To the original description we add the following obser- vations: frontoclypeus of male having a large median wart thickly beset with long, erect setae; vertex with deep groove along coronal sulcus and with anteromesal warts small and rounded, anterior warts absent, and posterior warts large. Female with tergum of segment $\mathrm{X}$ having setal warts extended posteriorly on either side as fingerlike processes, as in $P$. locumtenens.

\section{LARVA}

Unknown.

\section{MATERIAL EXAMINED}

NORTH KOREA-Hamgjong-pukto Province, Poro-chon River about $2 \mathrm{~km}$ nw. Kjong-song, 4.vi.1965, ð paratype (LB). Hamhyng-si Province, Hamdzu District, ca $15 \mathrm{~km} \mathrm{w}$. Hamhyng, Hyngpong-ri, 12.vi.1965, ㅇ paratype (LB).

\section{Psilotreta quadrata Schmid}

Psilotreta quadrata Schmid, 1959:327, pl. 4, figs. 8,9. Holotype ơ (Zoologisches Museum der Humboldt, Universität zu Berlin), China, Li-kiang, 22.v.1924.

This species is distinctive in several features, notably the complete fusion of the body of segment $\mathrm{X}$ and of the lateral processes with the median dorsal extension of segment $X$, forming a complete hood over the phallus, and the quadrate shape of the basal segment of the inferior appendage.

To the original description we add the following observations. Abdominal segment VII with a posterior lobe on the pleural membrane. Segment $X$ with basal setal wart indistinct and elongate, bearing several setae; median dorsal process with several short setae apically; lateral processes each with a narrow blunt projection arising from the basoventral border and curving posteriorly; the straight, more acute intermediate appendage arising from the posteroventral border of the body of segment $\mathrm{X}$ beneath the lateral process (Schmid, 1959, fig. 8, shows the projection of the lateral process apparently arising from the body of segment $\mathrm{X}$ beneath the intermediate appendage; the projection as illustrated also appears to be much longer than in the specimen we examined). Phallus with parameres short and talonlike, curved anterodorsally in lateral aspect and laterally in ventral aspect when in retracted position (shown in everted position in fig. 8 of Schmid, 1959).

\section{FEMALE AND LARVA}

Unknown.

\section{MATERIAL EXAMINED}

CHINA-North Yuennan Province, Li-kiang, 7.vii.1934, $\delta$ paratype (CNC). 


\section{Psilotreta schmidi sp. nov.}

This species is similar to both $P$. japonica and $P$. quadrata, but is distinct from all others of the genus in the inferior appendages having a ventral projection in lateral aspect and a prominent basomedian lobe in ventral aspect, and in the paired accessory phallic appendages being dorsad of the parameres.

\section{ADULT}

Maxillary palpi with first two segments subequal, slightly shorter than third and fourth, with fifth the longest, and with segments unmodified, setose. Clypeus convex, with scattered setae. Anteromedian warts of head slightly raised, with a moderately deep groove between them; anterior warts small, oval; posterior warts large, oval, extending about halfway to coronal suture. Tibial spurs 2 , 4, 4. Forewing 9-10 mm in length. Coloration brown; setae reddish or purplish. Forewing with discal cell present and approximately one-third length of wing; $R_{2}$ arising in basal one-third of discal cell and kinked at crossvein $r ; R_{4}$ and $R_{5}$ stalked. Hindwing with discal cell short, $R_{2}$ arising very close to $R_{1}$.

Male genitalia (Fig. 51). Segment VII with pleural membranes lacking posterior lobe. Segment IX with sides broad, with median dorsal projection long and fused with segment X throughout; basal segments of inferior appendages each with a median basal flange appearing as a broad triangle in ventral aspect and as a thin projection in lateral aspect, apical segments each dorsoventrally depressed and bearing numerous small black teeth on apical margin, both segments setose. Segment $X$ with preanal appendages thin, long, each dorsal edge being smoothly convex, each ventral edge being sinuous and strongly concave beyond base, apical third of each having dorsal and ventral edges subparallel and apex rounded and bearing scattered, long setae; median dorsal process in dorsal aspect broad and enlarged apically, with apex truncate to slightly emarginate and bearing a row of several long setae laterally on each side, in lateral aspect thin and free from body of segment $\mathrm{X}$ and lateral processes, extending posteriorly just beyond apex of each lateral process; body of segment $\mathrm{X}$ with apex bilobed in dorsal or ventral aspect, broad laterally, and with basal setal wart elongate and poorly defined; lateral processes long and broad, arising from middle of body of segment $X$, in lateral aspect projecting ventrally a short distance before turning posteriorly at right angles and ending in a slightly upcurved apex short of end of median dorsal process, and in dorsal or ventral aspects appearing as a thick rod tapering to an acute apex; intermediate appendages low, rounded, and inconspicuous, arising beneath lateral processes and extending anterad half the distance to the preanal appendages, free from the body of segment $X$ apically but scarcely visible or not visible in dorsal aspect.

Phallus stocky; phallotheca short and slightly constricted medially in lateral aspect. Endotheca inflated dorsally and bearing two pairs of sclerotized processes; parameres arising ventrally, large, broad, ventrally decurved in lateral aspect, and thin and forming a narrow $\mathrm{V}$ in ventral aspect; second pair of processes on endotheca short and roughly triangular, arising laterally, and projecting outwardly. Aedeagus with a cylindrical base, a prominent ventral lobe apically, and the phallotremal sclerite C-shaped in lateral view.

\section{FEMALE AND LARVA \\ Unknown.}

\section{MATERIAL EXAMINED}

(All specimens were collected by F. Schmid and are deposited in the CNC, Ottawa.) Holotype 0 : INDIA-Sikkim, Padamchen, 30.viii. 1959. Paratypes: INDIA-Sikkim, Manu, 5-6.viii.1959, 1 ठ (\#239); Rongne, 21.viii.1959, I के (\#238).

\section{ETYMOLOGY}

We take pleasure in naming this species in honour of its collector, Dr Fernand Schmid.

\section{Psilotreta assamensis sp. nov.}

This species is distinguished from other Asian species by the greatly reduced lateral processes of segment $\mathrm{X}$, by the long, slender, acute parameres, and by the inferior appendages, which are broad and have a ventromesal lobe.

\section{ADULT}

Forewing 9-12 mm in length in male, $14-17 \mathrm{~mm}$ in female. Head and thorax brown; antennae densely clothed with appressed white setae making them conspicuous in contrast with the rest of the insect; maxillary palpi dark brown; labial palpi light brown; forewings light brown with patches of yellowish setae between the veins in the middle of the wing and along the apical margin; hindwing uniformly light brown; forelegs light brown; middle and hind legs whitish.

Maxillary palpi with first two segments subequal and shorter than the rest, third and fifth subequal and about twice the length of the first or second and slightly longer than the fourth. Labial palpi with each segment slightly longer than the preceding. Vertex with anteromedian warts small, oval, and raised, a deep groove between them; anterior pair small, transversely oval, and slanting away from anteromedian pair; posterior warts twice as large as anterior warts, two pairs of small bumps between them; warts bearing long yellowish setae, with shorter setae 

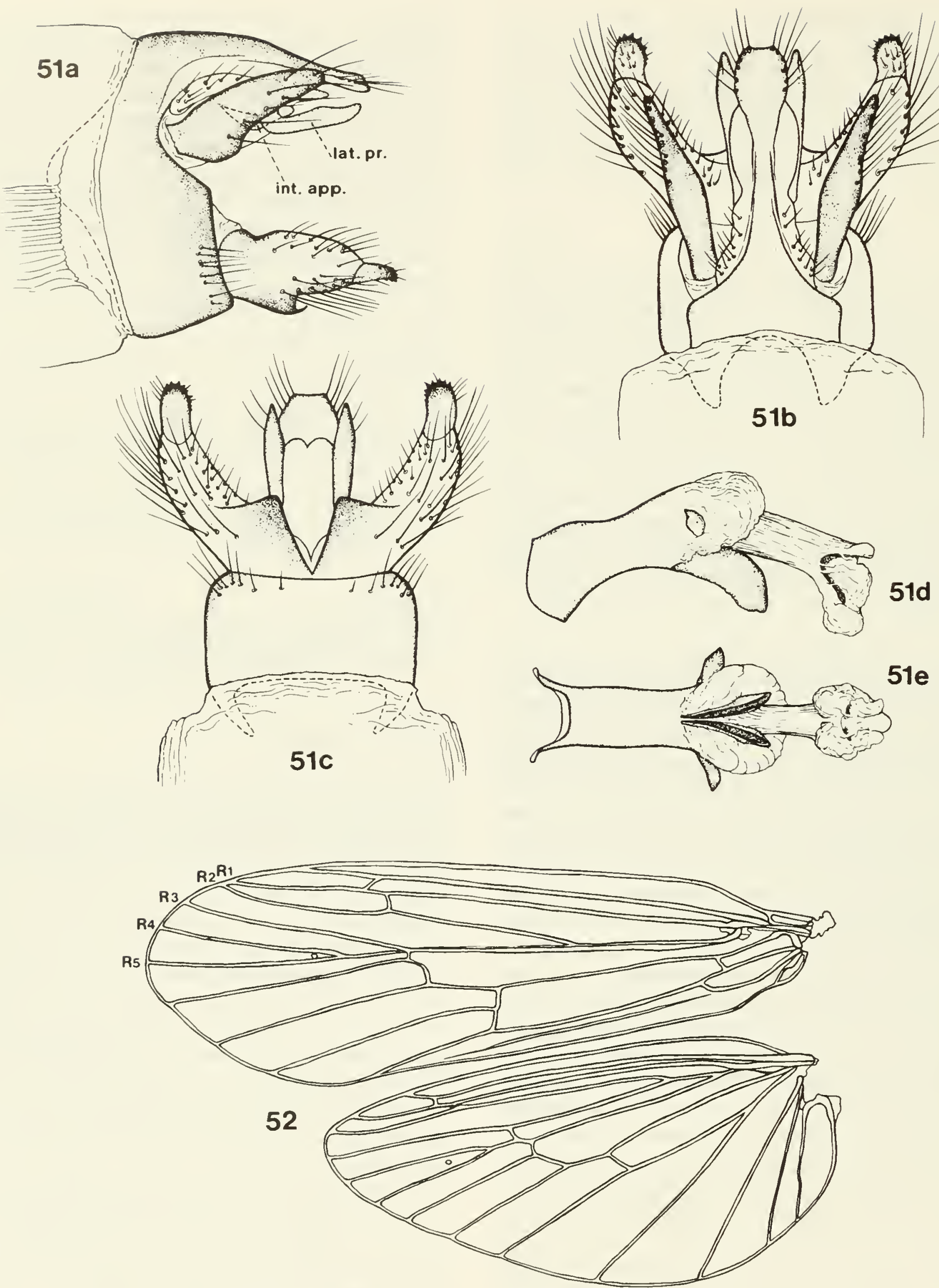

Figs. 51, 52. Psilotreta spp., adults. 51. P. schmidi: a-c, o genitalia-lateral, dorsal, ventral; $d, e$, phallus_lateral, ventral (int. app.—intermediate appendage; lat, pr.—lateral process). 52. P. chinensis, $\delta$ wings. 
between warts. Face with lateral warts extending from level of anterior tentorial pits to antennal sockets and bearing dark brown setae; frons without setae and indented above level of anterior tentorial pits to form the groove between the anteromedian warts. Eyes black, large, larger in male than female.

Venation in both sexes similar except forewing of female with $M_{1}$ and $M_{2}$ separated and thyridial cell present; forewing with discal cell present and extending about onethird length of wing, $R_{2}$ arising in basal fourth of discal cell and kinked at crossvein $r, R_{1}$ and $R_{2}$ converging near wing margin but not meeting, $\mathrm{R}_{3+4}$ branched beyond end of discal cell; hindwing with thyridial cell broad near origin of $\mathrm{Cu}_{1 \mathrm{~b}}$ in female, thyridial cell not broadened in male, $\mathrm{M}_{1+2}$ undivided in either sex.

Male genitalia (Fig. 53). Segment VII without pleural lobes. Segment IX with median dorsal process long and triangular and with base wide in dorsal aspect; inferior appendages each with a broad basal segment having a mesoventral lobe bearing several short, stiff, thickened setae at its apex, in addition to the longer, thinner setae scattered over the rest of the segment, and with a short apical segment having a broad base and narrow apex in lateral aspect, the apex broadly rounded in ventral aspect and bearing numerous short black teeth apically. Segment $\mathrm{X}$ with preanal appendages broadest in basal fourth, tapering gradually to apex, and bearing numerous short, stiff yellowish setae on basal half and long black setae on apical half, contrasting sharply in uncleared specimens with golden yellowish setae of rest of genitalia; median dorsal process long, acute or truncate in dorsal aspect, slightly enlarged apically in lateral aspect in some specimens, and bearing a row of about 10 stiff setae along each side near apex; body of segment $X$ broad in lateral aspect, largely membranous, sclerotized along ventral edge, fused dorsally to segment IX throughout its length; lateral process(?) greatly reduced, present as a sclerotized flange arising from dorsal edge of segment $X$ near midlength, becoming thicker and flared dorsolaterally, ending far short of apex of median dorsal process, and bearing dorsally on each side 1 to several setae, which may represent the basal setal wart(?); intermediate appendages(?) broad, curved, ramshornlike projections arising from apex of body of segment $X$ and curved apicodorsally.

Phallus with phallotheca long, cylindrical, slightly decurved and enlarged ventroapically; endotheca with pair of long, pointed, slightly curved parameres; aedeagus with ventral plate sclerotized, with membranous apex bilobed in ventral aspect, and with phallotremal sclerite elongate and $\mathrm{S}$-shaped in lateral aspect and having apex flared.

Female genitalia (Fig. 54). The female of $P$. assamensis is easily distinguished from the other species we examined by details of the vaginal chamber. Segment IX lacks depression laterally. Segment X with tergum deeply incised apically, narrowed and angular in lateral aspect. Median plate with weak median longitudinal suture. Posterior vaginal sclerites broad in lateral aspect, narrow in ventral aspect; dorsal edge above posterior sclerites broad in ventral aspect; anterior portion of vaginal chamber slightly longer than wide in ventral aspect.

\section{LARVA}

The larva of $P$. assamensis is unknown, but may correspond to Psilotreta sp. collected in Kameng, where the majority of the specimens of $P$. assamensis were collected.

\section{MATERIAL EXAMINED}

(All specimens were collected by F. Schmid and are deposited in the CNC, Ottawa, except for five paratypes in the ROM.)

Holotype o: INDIA-Assam, Kameng, Rahung, 17.vii.1961 (\#281). Paratypes: INDIA-Assam, Kameng: Amatulla, 17.v.1961, 3 ơ (\#192); Bilo La, 10.vi.1961, 1 ơ 2 क (\#241); Bokhar, 28.v.1961, 1 o (\#218); Chug, 25-31.vii.1961, 3 ठ 1 \& (\#300); same, 913.viii.1961, 1 क (\#307); Dirang Dzong, 18.vii.1961, 3 ò 1 (\#283); same, 21-22.vii, 2 (\#292); Kujjalong, 28-30.vi.1961, 1 \& (\#259), 1 ơ (\#260); Rahung, 16.vii.1961, 3 क (\#279); same, 17.vii.1961, 3 oे 1 \& (\#281); Salari, 10.vii.1961, 2 ơ 1 \& (\#275), 2 ơ (\#276). Sikkim: Dikchu, 9.v.1959, I ơ (\#119); Lingtham, 810.viii.1959, 1 के (\#243); Mangang, 9.v.1959, 1 ठ (\#122); Nampung, 8.v.1959, I के (\#116); Singhik, 710.viii.1959, I o (\#242). Non-type specimens: the following four females are not included in the type series because they were not collected in association with males. INDIA-Assam, Kameng: Lifakpo, 29.v.1961, I \& (\#222); Moshing, 8-10.ix.1961, 1 \& (\#333); Jhum La, 15-22.ix.1961, 1 \& (\#337); Talung Dzong, 3.vi.1961, 1 q (\#228).

\section{Psilotreta sp.}

The larvae and pupae described here may be $P$. assamensis; they were collected in Kameng, some of them from the same locality as one of the non-type females listed under that species. However, since the pupae are insufficiently developed, except one female pupa which had rotted and could not be identified, we choose not to assign a name to this larva until better evidence becomes available.

\section{LARVA (Figs. 43-45)}

General appearance typical for genus. Head without distinct colour pattern but dorsal surface light, with contrasting dark muscle scars and irregular darker areas on 

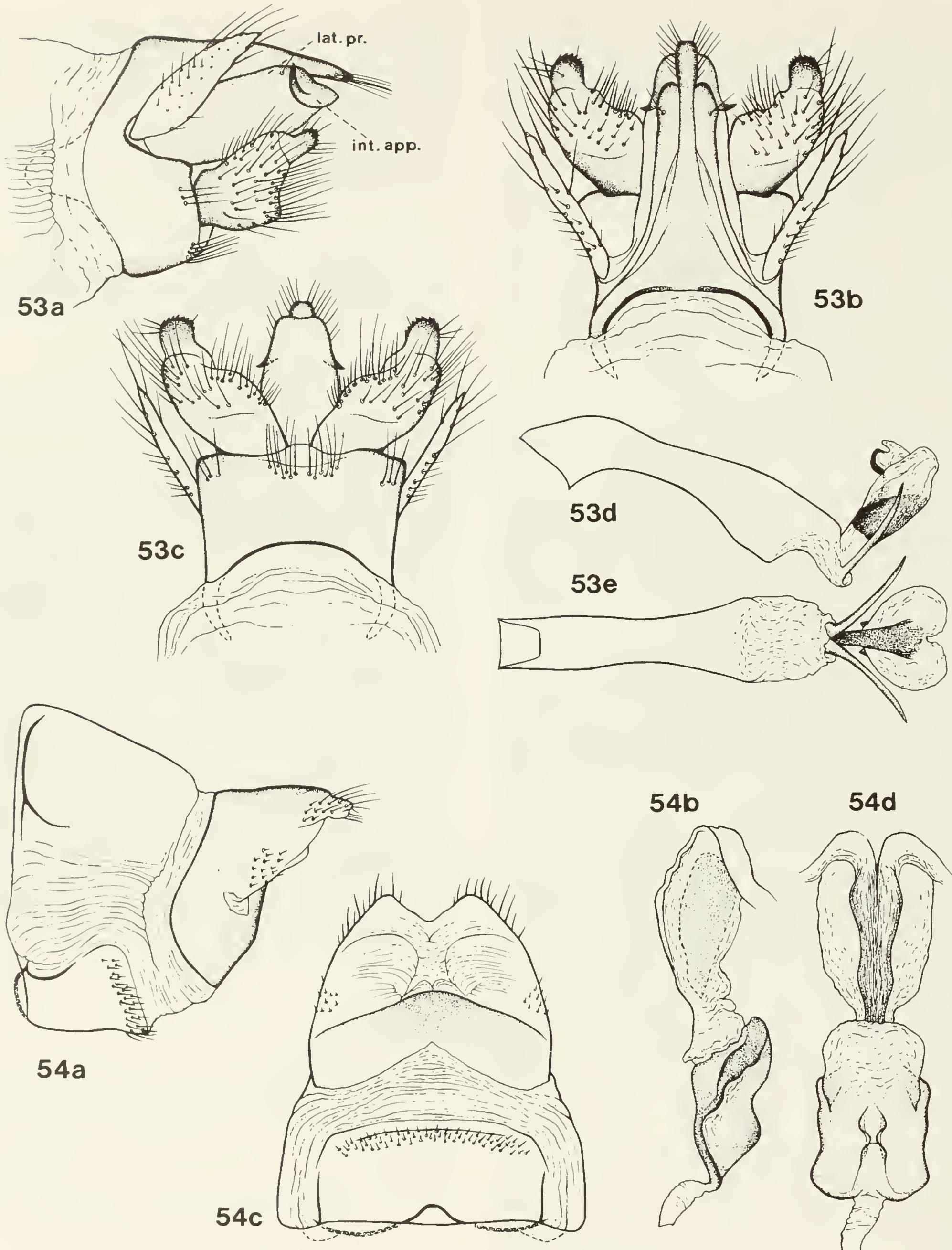

54d

FIGs. 53, 54. Psilotreta assamensis. 53. $a-c$, ठ̊ genitalia-lateral, dorsal, ventral; $d, e$, phallus-lateral ventral (int. app.-intermediate appendage; lat. pr.-lateral process). 54. a,c, $\&$ genitalia-lateral, ventral. $b, d$, vaginal apparatus-lateral, ventral. 
parietals along anterior border with frontoclypeus; head much darker posteriorly and ventrally, with a large light area around eyes. Pronotum brown, with lighter areas laterally, and posterior ridge black. Mesonotum brown, with lighter areas at anterolateral corner and at bases of some of the larger dorsal setae, and with posterior ridge black from middorsal line to ventrolateral border. Metanotum with anterior sclerite brown, lateral borders yellowish, lateral sclerites brown and having some darkening posterodorsally, and posterior sclerite light yellowish brown. Pleurites brown with suture and anterior borders black; legs light brown basally with distal segments becoming darker and with proximal articulation of coxae and femora blackened.

Head longer than wide; seta 17 slightly more than onehalf length of, and similar in appearance to, seta 15. Pronotum with anterolateral corner of size and shape similar to $P$. frontalis, approximately $0.2 \times$ middorsal length of tergite and slightly upcurved. Mesonotum with posterior inflection indicated as a short, thin, light streak extending anteriorly from ventrolateral extent of posterior ridge, and without an indentation along posterior margin of sclerite; mesepisternum with anteroventral corner slightly produced ventrally; mesofemur with 1 to 2 secondary setae arising dorsally basad of seta 1 and slightly shorter and thinner than seta 1, and with position of ventral seta 3 variable relative to dorsal seta 1 and ventral setae 4 and 5 . Metanotum (Fig. 45) with anterior sclerite bearing 34-46 setae, posterior bearing 16-20, each lateral bearing 28-37. Abdominal segment VIII bearing 20 lateral tubercles on each side. Abdominal gills: dorsal-II 23-25, III 30-33, IV 24-25, V 17-20, VI 12-13, VII 9-10, VIII 9-12; lateral-III 5-7; ventral-II 19-23, III 26-30, IV 26-27, V 24-25, VI 20-23, VII 16-22, VIII 9-14. Larva up to 12 $\mathrm{mm}$ in length; head up to $1.3 \mathrm{~mm}$ in width across eyes. Larval case typical for genus, tapered and curved in early instars and curved with little or no taper in final instar; posterior end with a single rock fragment cemented over opening; case up to $18 \mathrm{~mm}$ in length.

Plupa (Fig. 10a,b). The pupa of this species is described in the generic diagnosis. Pupal case typical for genus, up to $18 \mathrm{~mm}$ in length.

\section{MATERIAI, EXAMINED}

INDIA-Assam, Kameng: Jhum La, 17.ix.1961, many L, I P (decomposed) (ROM); Kalaktang, 14.v.1961, many L and PP, 3 P (ROM).

\section{NOTES}

The position of ventral seta 3 of the femur (Fig. 43) is variable relative to the position of dorsal seta 1 and ventral setae 4 and 5 , being distad of 1 by less than the distance between 4 and 5 in most specimens, and by approximately the same or a greater distance in other specimens. This may be because of difficulty in interpretation owing to the presence of the secondary dorsal setae, or it may indicate that there are two closely similar species present.

The occurrence of early instars and pupae in samples in May and September may indicate a life cycle requiring at least two years for completion, as is found in Nearctic species, coupled with prolonged emergence of adults. It is also possible that two species are present, as suggested above.

\section{Psilotreta kwantungensis Ulmer}

Psilotreta kwantungensis Ulmer, 1925:66-68, figs. 49-52. Holotype ơ (ZIM), China, Lienping, 8.iv. 1920.

This species is most closely related to $P$. lobopennis Hwang; both have the median dorsal process of segment $X$ produced as a long narrow hood overhanging the rest of the segment, and have inferior appendages each with the basal segment bearing prominent dorsal and ventral lobes and with the apical segment arising between the lobes. The male of $P$. kwantungensis is distinguished from those of $P$. lobopennis by the longer apex of the body of segment $\mathrm{X}$ and by the shorter ventral lobe of the basal segment of the inferior appendage.

\section{ADULT}

Forewing $10 \mathrm{~mm}$ in length in male, $12 \mathrm{~mm}$ in female. Head and thorax brown; abdomen blackish; antennae whitish; legs lighter than thorax; wings uniformly brown. Venation (Ulmer, 1925, figs. 49, 50) without modifications; discal cell present and short, with $\mathrm{R}_{2}$ having a kink at crossvein $\mathrm{r}$.

Male genitalia (Fig. 55). Segment VII with posterior lobe on pleural membrane. Segment IX with anterolateral lobe large; small wartlike setal patches present laterally and ventrally near insertion of inferior appendage; median dorsal process of segment IX indistinguishably fused with that of segment $X$, together forming a long, narrow hood overhanging body of segment $X$, in dorsal aspect slightly constricted at base, broader and parallel sided beyond base to rounded apex, and bearing several setae; inferior appendages with basal segment C-shaped in lateral aspect, thumblike dorsal lobe and longer ventral lobe bearing several short stiff setae at apex, in addition to longer setae scattered over rest of segment, in ventral aspect with broad darker area free of setae, extending along mesal margin, and slightly produced at apex, and with lighter setate ventral lobe narrowing to apex from this point; inferior appendages with apical segment arising subapically in C-shaped basal segment, triangular in lateral aspect, dorsoventrally depressed, having apex rounded in dorsal aspect, 


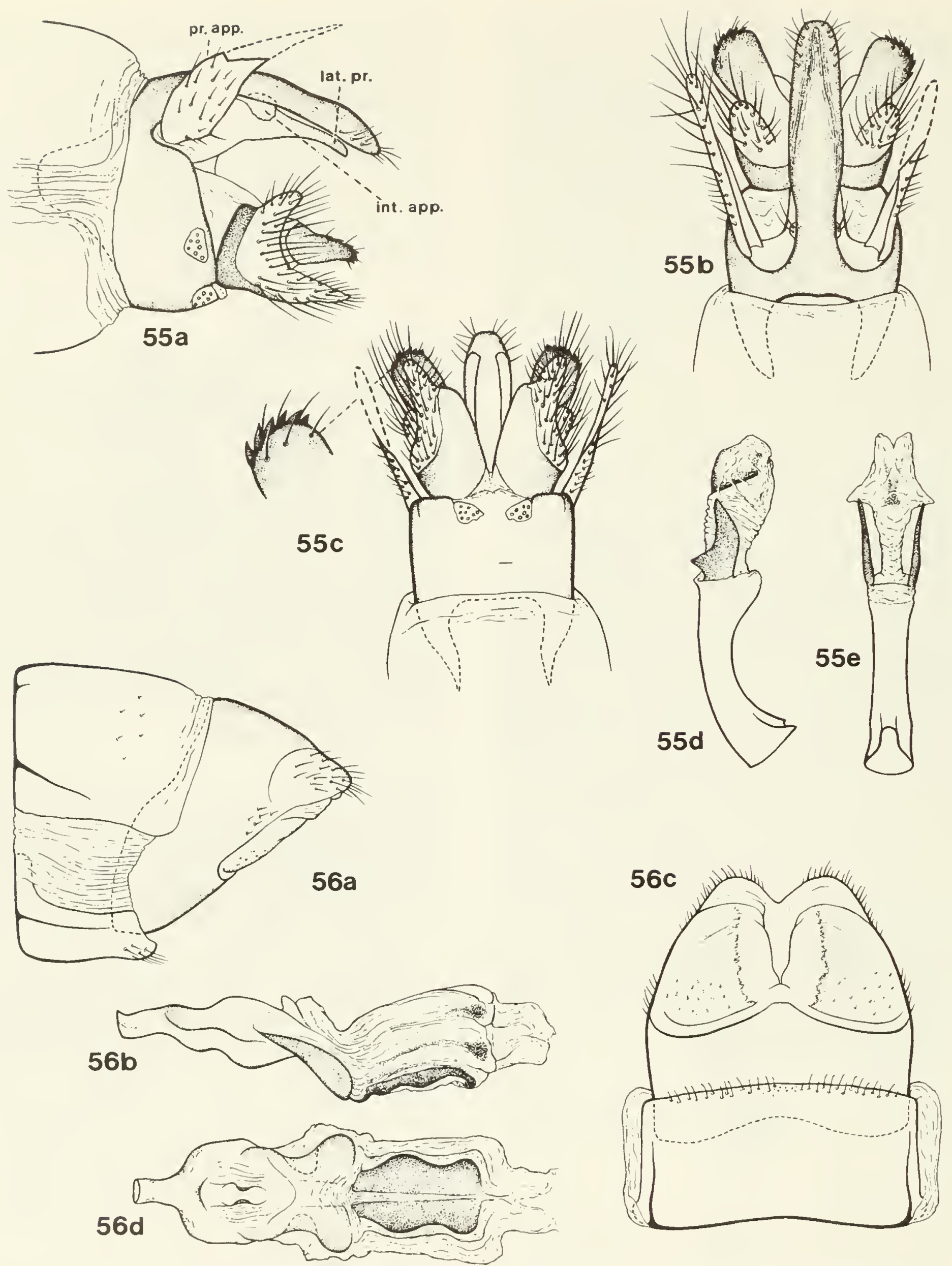

Figs. 55, 56. Psilotreta kwantungensis. 55. a-c, ơ genitalia, holotype, Lienping, China-lateral, dorsal, ventral with detail of apex of inferior appendage; right preanal appendage on type broken as shown, with outline of left appendage dotted in lateral aspect; $d, e$, phallus-lateral, ventral (int. app.--intermediate appendage; lat. pr.--lateral process; pr. app.-preanal appendage). 56. a,c, $\$$ genitalia, paratype, Mahntsishan, Chinalateral, ventral; $b, d$, vaginal apparatus-lateral, ventral. 
and bearing eight to nine short black spines along apical margin. Segment $X$ with body fused to segment IX only near base, completely free from median dorsal process; lateral processes(?) small, thin, rounded lobes arising near midlength of body of segment $X$; intermediate appendages projecting posteriorly from apex of body of segment $\mathrm{X}$ and extending beneath median dorsal process nearly to apex; preanal appendages broad basally, with apical half very narrow and bearing scattered long setae.

Phallus with phallotheca cylindrical and curved in lateral aspect and both basal and apical ends produced ventrally. Endotheca bearing large parameres laterally; base broad in lateral aspect, with a large triangular dorsal projection near base; ventral margin angled upwards to an acute apex at about midlength, in ventral aspect appearing as a thin rod. Aedeagus membranous throughout with two triangular lobes near midlength and with apex bifid in ventral aspect; phallotremal sclerite with anterior margin straight, apex flared in ventral aspect.

Female genitalia (Fig. 56). The female of this species is easily distinguished from the others we have examined by the absence of a sulcus on the posterior portion of sternum IX and by details of the vaginal chamber.

Segment IX with tergum lacking depression laterally; posterior portion of sternum IX lacking suture and set off from posteroventral lobes of tergum $X$ by sharp ridge. Segment $X$ with apex rounded in lateral aspect. Vaginal chamber with anterior portion bearing low ventromedian projection; posterior portion with three layers of sclerotiza- tion, the ventral layer more heavily sclerotized than the other two, and in ventral aspect with sinuous outer margin.

\section{LAR VA}

Unknown.

MATERIAL EXAMINED

CHINA-Lienping, 8.iv.1920, holotype ơ (ZIM). Mahntsishan, 20.vii.1915, paratype $q$ (ZIM).

\section{Psilotreta trispinosa Schmid}

Psilotreta trispinosa Schmid, 1965:148, pl. 7, figs. 9, 10. Holotype ơ (Alexander Koenig Museum, Bonn), China, Wenchow, 15 April 1939.

This species is easily recognized by the distinctive threespine arrangement of the lateral processes and intermediate appendages of segment $X$.

To the original description we add abdominal segment VII with pleural membranes only slightly produced posteriorly.

FEMALE AND LARVA

Unknown.

MATERIAL EXAMINED

CHINA-Wenchow (Chekiang), 18.iv.1939, paratype ${ }^{*}$ (CNC).

\section{Species Not Examined}

Psilotreta lobopennis Hwang, 1957:394-395, figs. 96-99, o, China.

Psilotreta ochina Mosely, 1942:345-346, figs. 6-8, o $q$. Holotype $\delta$ (BMNH), China, vicinity of Foochow, 1935-1937.
Psilotreta orientalis Hwang, 1957:393-394, figs. 92-95, o. China.

Psilotreta quinlani Kimmins, 1964:49-50, figs. 38-43, ठ . Holotype ơ (BMNH), Nepal, Ulleri, 1830-2135 m, 19.v.1954. 


\section{Phylogenetic and Biogeographic Considerations}

Twenty species of Psilotreta are now recognized; 6 are known from eastern North America, and 14 from Nepal, India, China, Korea, Siberia, and Japan. These two geographic groups are also separated phylogenetically, the North American species forming a monophyletic assemblage distinct from the Asian species.

Monophyly of the Nearctic species is supported by two characters in the male genitalia. All lack parameres on the phallus, whereas all the Asian species possess parameres. Since the presence of parameres is a plesiomorphic condition in Trichoptera (Nielsen, 1957, 1981; Schmid, 1970, 1980), absence of these structures in the North American Psilotreta is a synapomorphy uniting these species in a monophyletic group. On all North American Psilotreta the apical segments of the inferior appendages bear a few relatively stout black teeth (e.g., Figs. 11c, 17c), whereas most of the Asian Psilotreta have numerous small spines (e.g., Figs. 46c, 48c). Numerous small spines is the probable plesiomorphic condition; certain other genera of odontocerids have numerous very small spines (e.g., Odontocerum, Marilia, Nerophilus), and the same condition occurs in the sister family of the odontocerids, the Philorheithridae. Thus, we propose that a reduced number (fewer than 10) of larger teeth on the apical segment of the inferior appendages in the North American species, and at least one Asian species, is an apomorphic condition. It is probable that this condition in the Asian species $P$. kwantungensis (Fig. 55c) (and P. lobopennis?) is independently derived, since it is associated with a dorsoventral depression of the apical segment which does not occur in the North American species. We have not been able to examine the females, larvae, or pupae of a sufficient number of Asian species to detect any characters of phylogenetic value in these stages.
Further analysis of the phylogenetic relationships among the North American species was carried out by means of an outgroup analysis using the Asian Psilotreta, the other genera of the Odontoceridae, and other limnephiloid families as the outgroups. Characters for which hypotheses of ancestral and derived states could be developed are listed in Table 1. In the cladogram (Fig. 57) resulting from the analysis in Table 1, two clusters of three species each are proposed - the indecisa and rufa subgroups. The species in these two groups are readily resolved as three-taxon statements.

Published descriptions of the Asian species that we have not examined are inadequate for phylogenetic analysis; however, we advance the following observations. Certain groups of closely related species can be recognized among the Asian Psilotreta. The three species $P$. kisoensis, $P$. falcula, and $P$. locumtenens share apparently derived characteristics:" the lateral processes of segment $X$ are bean shaped and lack projections, and the basal segment of each of the inferior appendages has an apical projection ventrally. $P$. kwantungensis and $P$. lobopennis Hwang are sister species as indicated by the fused condition of the median dorsal and the lateral processes of segment $\mathrm{X}$ and

\footnotetext{
* While this manuscript was in press, we noted the description of a new species of Psilotreta from Korea, $P$. pyonga Olah, 1985 (J. Olah, 1985, Threc new Trichoptera from Korca. Folia Entomologica Hungarica 46(1):137-142). The species as described is difficult to distinguish from $P$. falcula Botoşăneanu, with which it is closely related, if not conspecific. Comparison of types and of variability in series of the two species will be required to confirm the validity of $P$. pyonga.
}

TABLE 1. Character states for cladistic analysis of North American Psilotreta species.

\begin{tabular}{|c|c|c|}
\hline Character & $\square$ Plesiomorph State & Apomorph State \\
\hline 1. Parameres of male & present & absent \\
\hline $\begin{array}{l}\text { 2. Spines on apical segment of inferior } \\
\text { appendage }\end{array}$ & numerous, small & few, large \\
\hline $\begin{array}{l}\text { 3. Median dorsal process of segment X } \\
\text { of malc }\end{array}$ & well developed, sclerotized & reduced, membranous \\
\hline 4. Larval head seta 17 & long, thick, dark & short, thin, clear \\
\hline 5. Larval head capsule & flat dorsally & domed dorsally \\
\hline 6. Warts on vertex of male & small, unmodified & $\begin{array}{l}\text { very large, raised medially, with scalelike } \\
\text { setae }\end{array}$ \\
\hline 7. Hindwing of female & discal cell closed & discal cell open \\
\hline 8. Maxillary palp of male & unmodified & second segment with eversible lobe \\
\hline 9. Vertex of male & without eversible lobes & with paired eversible lobe \\
\hline
\end{tabular}




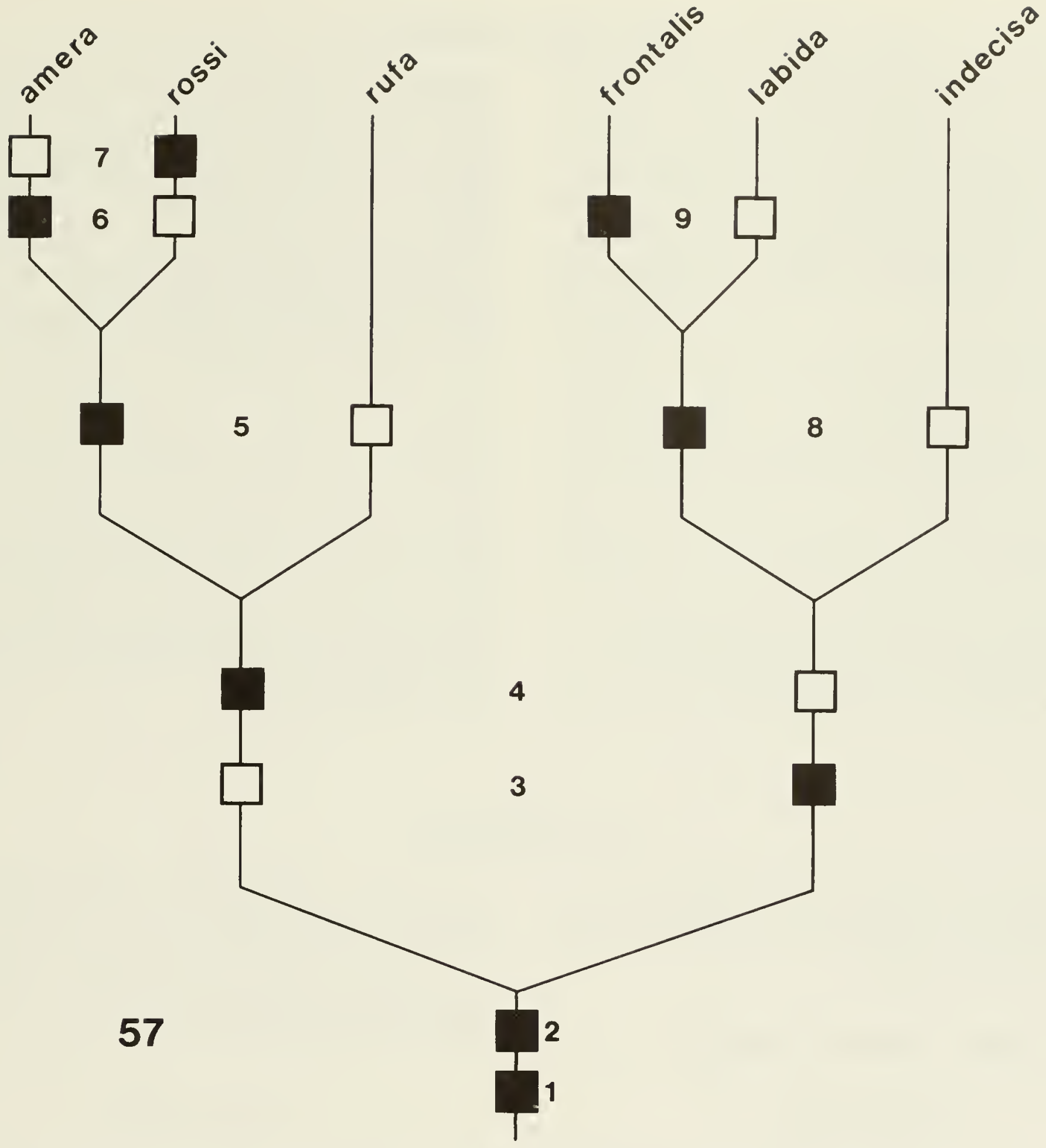

Fig. 57. Cladogram for the North American species of Psilotreta. Characters numbered as in Table 1; open squares represent plesiomorph character states, closed squares represent apomorph character states. 
by the C-shaped basal segment of the inferior appendages. The new species, $P$. schmidi, appears most closely related to $P$. japonica because of the orientation and shape of the projection of the lateral processes, the reduced intermediate appendages of segment $\mathrm{X}$, and the basomesal projection of the first segment of the inferior appendages. Two species that we have not examined ( $P$. ochina Mosely and $P$. orientalis Hwang) appear from the illustrations and descriptions to be related on the basis of the unique footshaped apical segment of each inferior appendage, and perhaps also on the basis of the apex of the median dorsal process of segment $X$, which is very wide in lateral aspect. Kimmins (1964) has suggested that $P$. orientalis is related to $P$. quinlani Kimmins on the basis of the structure of segment $\mathrm{X}$; however, if the illustrations and descriptions of the two species are accurate, it is difficult to relate these two species very closely. In fact, $P$. quinlani may have more in common with $P$. trispinosa, the only other species having bifurcate intermediate appendages. The remaining species are rather isolated from the rest of Psilotreta: $P$. chinensis because of the very short preanal appendages, the dorsal projection of the lateral processes of segment $X$, and the accessory processes of the endotheca; $P$. assamensis because of the reduced lateral appendages; and $P$. quadrata because of the fused condition of the median dorsal process of segment $\mathrm{X}$ with the lateral processes to produce a large hood over the phallus, and the distinctive inferior appendages. The association of larvae and females of more of the species will improve our understanding of the relationships within Psilotreta. We also expect that many undescribed species remain to be discovered in Asia.

The disjunct distribution of the species of Psilotreta in temperate eastern Asia and eastern North America coincides with a widely recognized global biogeographic pattern (Boufford and Spongberg, 1983). Yet, absence of Psilotreta from Europe is at variance with the generalization, derived from analysis of several arthropod lineages, that the faunas of Europe and eastern North America have shared a more recent common biota than either has shared with Asia (Allen, 1983). The sister genus of Psilotreta appears to be the European Odontocerum, giving further support to a Eurasian origin for Psilotreta. The fact that the Nearctic component of Psilotreta is a derivative group is consistent with the suggestion (Schmid, 1970:107) that the more primitive elements of lotic lineages in Trichoptera have an Oriental origin.

\section{List of Species}

The 20 species of Psilotreta are listed with their distributions and references to figures. New synonymies established herein also are listed.

\section{NORTH AMERICAN SPECIES}

\author{
indecisa Group \\ indecisa Subgroup
}

P. indecisa (Walker, 1852). Eastern North America. Figs.

$1,4,5,10 \mathrm{c}, 11,12,24,25,32,38$.

Heteroplectron borealis Provancher, 1877.

P. frontalis Banks, 1899. Eastern North America. Figs. 2, 13, 14, 26, 33, 38.

P. hansoni Denning, 1948. Status unconfirmed.

P. labida Ross, 1944. Eastern North America. Figs. 9, 15, $16,27,34,38$.

rufa Subgroup

P. rufa (Hagen, 1861). Eastern North America. Figs. 6-8, $17,18,28,29,35,39$.

Heteroplectron? dissimilis Banks, 1897.
P. amera Ross, 1939. Georgia, North Carolina, South Carolina, Tennessee. Figs. 3, 22, 23, 31, 37, 39.

P. rossi Wallace, 1970. North Carolina, Virginia, West Virginia. Figs. 19-2 1, 30, 36, 39.

\section{ASIAN SPECIES}

P. japonica (Banks, 1906). Japan. Figs. 46, 47.

$P$. schmidi sp. nov. Eastern India. Fig. 51.

$P$. falcula Botoşăneanu, 1970. North Korea.

P. kisoensis Iwata, 1928. Japan. Figs. 40-42.

$P$. locumtenens Botoşăneanu, 1970. North Korea.

P. kwantungensis Ulmer, 1925. China. Figs. 55, 56.

P. lobopennis Hwang, 1957. China.

$P$. ochina Mosely, 1957. China.

$P$. orientalis Hwang, 1957. China.

$P$. quinlani Kimmins, 1964. Nepal.

P. trispinosa Schmid, 1965. China.

P. chinensis Banks, 1940. China. Figs. 48-50, 52.

P. assamensis sp. nov. Eastern India. Figs. 53, 54.

P. quadrata Schmid, 1959. China. 


\section{Acknowledgements}

This study was conducted under the support of an operating grant (to G. B. Wiggins) from the Natural Sciences and Engineering Research Council of Canada. Earlier fieldwork was supported by research grants (to G. B. Wiggins) from the National Science Foundation of the United States and the Canadian National Sportsmen's Show. To these sources and to the individuals and institutions listed previously as sources of additional material, especially type specimens, we extend sincere appreciation. O. S. Flint assisted in providing references and specimens. J. C. Morse reviewed the manuscript and provided helpful comments on the interpretation of venation; F. Schmid also reviewed the manuscript. Zile Zichmanis drew all the illustrations, except for Fig. 8a-c,g, which were drawn by Anker Odum. Nina Cunniff assisted in compiling locality data. Susan Pasch and E. R. Fuller helped to organize and check the manuscript. 



\section{Literature Cited}

ALLEN, R. T.

1983 Distribution patterns among arthropods of the north temperate deciduous forest biota. Annals of the Missouri Botanical Garden 70:616-628.

BANKS, N.

1897 New North American neuropteroid insects. Transactions of the American Entomological Society $24: 21-$ 31.

1899 Descriptions of new North American neuropteroid insects. Transactions of the American Entomological Society 25:199-218.

1906 New Trichoptera from Japan. Proceedings of the Entomological Society of Washington 7:106-112.

1914 American Trichoptera-notes and descriptions. Canadian Entomologist 46: 149-156, 201-205, 252258, 261-268.

1940 Report on certain groups of neuropteroid insects from Szechwan, China. Proceedings of the United States National Museum 88(3079): 173-220.

BETTEN, C.

1934 The caddis flies or Trichoptera of New York state. New York State Museum Bulletin 292:1-576.

BETTEN, C. and M. E. MOSELY

1940 The Francis Walker types of Trichoptera in the British Museum. London, British Museum (Natural History). $248 \mathrm{pp}$.

BOTOŞĂNEANU, L.

1970 Trichoptères de la République Démocratique-Populaire de la Corée. Annales Zoologici 27:275-359.

BOUFFORD, D. E. and S. A. SPONGBERG

1983 Eastern Asian-Eastern North American phytogeographical relationships - a history from the time of Linnaeus to the twentieth century. Annals of the Missouri Botanical Garden 70:423-439.

CORBET, P. S., F. SCHMID, and C. L. AUGUSTIN

1966 The Trichoptera of St. Helen's Island, Montreal. I. The species present and their relative abundance at light. Canadian Entomologist 98:1284-1298.

DENNING, D. G.

1948 Descriptions of eight new species of Trichoptera. Bulletin of the Brooklyn Entomological Socicty 43:119-129.

1950 Order Trichoptera, the caddisflies. In Wray, D. L., ed., Insects of North Carolina. Ralcigh, North Carolina Dept. of Agriculture, pp. 19-23.

EDWARDS, S. W.

1966 An annotated list of the Trichoptera of middle and west Tennessec. Journal of the Tennessee Academy of Science $41: 116-128$.
GRAHAM, A. C.

1982 Life history and population ecology of Psilotreta rufa (Hagen) (Trichoptera: Odontoceridae). 13th Annual Meeting of the North American Benthological Society, May 18-21, 1982, University of Michigan, Ann Arbor. [Abstract]

HAGEN, H. A.

1861 Synopsis of the Neuroptera of North America, with a list of the South American species. Smithsonian Miscellaneous Collections. Washington, Smithsonian Institution. $347 \mathrm{pp}$.

HARPER, P. P., J. C. PILON, and J.-M. PERRON

1975 Insectes aquatiques du nord du Québec (Ephémeroptères, Odonates, Plecoptères et Trichoptères). Annales de la Société entomologique du Québec $20: 33-43$.

HILSENHOFF, W. L.

1981 Aquatic insects of Wisconsin. University of Wisconsin-Madison, Natural History Council Publication $2: 1-60$.

HOLZENTHAL, R. W., S. C. HARRIS, and P. K. LAGO

1982 An annotated checklist of caddisfies (Trichoptera) of Mississippi and southeastern Louisiana. 1II. Limnephiloidea and conclusions. Proceedings of the Entomological Society of Washington 84:513-520. HWANG, C.-L.

1957 Descriptions of Chinese caddisflies (Trichoptera). Acta Entomologica Sinica 7:373-404.

HYLAND, $K$.

1948 New records of Pennsylvania caddis flies (Trichoptera). Entomological News 59:38-40.

IWATA, M

1928 Trichopterous larvae from Japan. III. Dobutsugaku Zasshi 401:115-130.

KIMMINS, D. E.

1964 On the Trichoptera of Nepal. Bulletin of the British Museum (Natural History), Entomology 15:33-55.

LAKE, R. W.

1984 Distribution of caddisfies (Trichoptera) in Delaware. Entomological News 95:215-224.

LEPNEVA, S. G.

1958 Die zweite Gattung und Art der Odontoceridac (Trichoptera, Integripalpia) in der U.S.S.R. Entomologicheskoe Obozrenic, Moskva-Leningrad 37:914-919.

1966 Fauna SSSR, Rucheiniki, vol. 2, no. 2. Lichinki i kukolki podotryada tsel'noshchupikovykh. Zoologicheskii Institut Akademiia Nauk SSSR, n.s. 95. [In Russian. Translated into English as Fauna of the U.S.S.R.; Trichoptera, vol. 2, no. 2. Larvae and Pupae of Integripalpia. Published by the Israel Program for Scicntific Translations, 1971.] 
LLOYD, J. T.

1921 The biology of North American caddisfly larvae. Lloyd Library of Botany, Pharmacy and Materia Medica, Bulletin 21, Entomological Series 1:1-124.

LONGRIDGE, J. L. and W. L. HILSENHOFF

1972 Trichoptera (caddisflies). In Aquatic insects of the Pine-Popple River, Wisconsin. Wisconsin Dept. of Natural Resources, Technical Bulletin 54:20-30.

1973 Annotated list of Trichoptera (caddisflies) in Wisconsin. Wisconsin Academy of Science, Arts and Letters 61:173-183.

MARTYNOV, A. B.

1933 On the interesting collection of Trichoptcra from Japan. Annotationes Zoologicae Japonenses 14:139156.

McElvray, E. P., T. L. ARSUFFI, and B. A. FOOTE

1977 New records of caddisflies (Trichoptera) for Ohio. Proceedings of the Entomological Society of Washington 79:599-604.

MILNE L. J.

1934 Studies in North American Trichoptera. Part I. Cambridge, published by the author, pp. 1-19.

1936 Studies in North American Trichoptera. Part 3. Cambridge, published by the author, pp. 56-128.

MORSE, J. C., J. W. CHAPIN, D. D. HERLONG, and R. S. HARVEY

1980 Aquatic insects of Upper Three Runs Creek, Savannah River Plant, South Carolina. Part I. Orders other than Diptera. Journal of the Georgia Entomological Society 15:73-101.

MORSE, W. J. and R. L. BLICKLE

1953 A check list of the Trichoptera (caddisflies) of New Hampshire. Entomological News 64:68-73, 97102.

MOSELY, M. E.

1942 Chinese Trichoptera: a collection made by Mr. M. S. Yang in Foochow. Transactions of the Royal Entomological Society, London 92:343-362.

NEVES, R. J.

1979 A checklist of caddisflies (Trichoptera) from Massachusetts. Entomological News 90:167-175.

NIELSEN, A.

1957 A comparative study of the genital segments and their appendages in male Trichoptera. Kongelige Danske Videnskabernes Selskab, Biologiske Skrifter 8:1-159.

1981 On the evolution of the phallus and other male terminalia in the Hydropsychidae with a proposal for a new generic name. In Moretti, G. P., ed., Proceedings of the Third International Symposium on Trichoptera, Perugia, Italy. Series Entomologica 20. The Hague, Junk, pp. 273-278.

PROVANCHER, $M$.

1877 Faune canadienne. Les Insectes-Névroptères. Le Naturaliste canadien 9:257-269.
ROBERT, A.

1960 Les Trichoptères de la région du Lac Munroe, Parc du Mont Tremblant, Qućbec. Annales de la Société entomologique du Québec 4:47-6!.

ROSS, H. H.

1938 Lectotypes of North American caddisflies in the Museum of Comparative Zoology. Psyche 45:1-61.

1939 New species of Trichoptera from the Appalachian Region. Proceedings of the Entomological Society of Washington 41:65-72.

1944 The caddis flies, or Trichoptera, of Illinois. Bulletin of the Illinois Natural History Survey 23:1-326.

ROY, D. and P. P. HARPER

1975 Nouvelles mentions de Trichoptères du Québec et description de Limnephilus nimmoi sp. nov. (Limnephilidae). Canadian Journal of Zoology 53:1080 1088.

1979 Liste preliminaire des Trichoptères (insectes) du Québec. Annales de la Société entomologique du Québec 24:148-172.

SCHMID, F.

1959 Quelques Trichoptères de Chine. Mitteilungen aus dem Zoologischen Muscum in Berlin 35:317-345.

1965 Quelques Trichoptères de Chine. II. Bonner zoologische Beiträge 16:127-154.

1970 Le genre Rhyacophila Pictet et la famille des Rhyacophilidae (Trichoptera). Memoirs of the Entomological Society of Canada 66:1-230.

1980 Les insectes et arachnides du Canada. Partie 7. Genera des Trichoptères du Canada et des États adjacents. Agriculture Canada Publication 1692:1296.

1983 Révision des Trichoptères canadiens. III. Les Hyalopsychidae, Psychomyiidae, Goeridae, Brachycentridae, Sericostomatidae, Helicopsychidae, Beraeidae, Odontoceridae, Calamoceratidae et Molannidae. Mémoires de la Société entomologique du Canada 125:1-109.

SIBLEY, C. K.

1926 Studies on Trichoptera. In A preliminary biological survey of the Lloyd-Cornell Reservation. Lloyd Library of Botany, Pharmacy and Materia Medica, Bulletin 27, Entomological Series 5:102-108, 185221.

TSUDA, M.

1942a Japanische Trichopteren. I. Systematik. Memoirs of the College of Science, Kyoto Imperial University, Series B, 17:239-339.

1942b Correction of names of Japanese Trichoptera larvae. Zoological Magazine, Tokyo 54:39-50.

1958 Present knowledge of Japanese caddis-fly larvae. Kontyu 26:168-174.

1959 Trichoptera. In Illustrated insect larvae of Japan. Tokyo, Hokuryukan, pp. 126-154.

1935 Insects of Jehol (iii). Trichopterous larva and pupa. 
Report of the First Scientific Expedition to Manchoukuo. Tokyo. Part 7, article 27, 10 pp.

ULMER, G.

1907a Trichopteren. Collections zoologiques du Baron Edm. de Selys Longchamps, Catalogue, Fascicule VI, pp. 1-102.

1907b Trichoptera. Genera Insectorum 60, $259 \mathrm{pp.}$

1925 Beiträge zur Fauna Sinica. III. Trichopteren und Ephemeropteren. Archiv für Naturgeschichte 91:19110.

UNZICKER, J. D.

1968 The comparative morphology and evolution of the internal female reproductive system of Trichoptera. Illinois Biological Monographs 40:1-72.

WALKER, F.

1852 Catalogue of the specimens of neuropterous insects in the collection of the British Museum. Part 1. London. $192 \mathrm{pp}$.

WALLACE, J. B.

1970 A new species of Psilotreta from North Carolina (Trichoptera: Odontoceridae). Entomological News 81:243-245.
WIGGINS, G. $B$.

1977 Larvae of the North American caddisfly genera (Trichoptera). Toronto, University of Toronto Press. 401 pp.

1978 Trichoptera. In Merritt, R. W. and K. W. Cummins, eds., An introduction to the aquatic insects of North America. Dubuque, lowa, Kendall/Hunt, pp. 149185.

WILLIAMS, N. E.

1983 A comparative study of chaetotaxy in larval Trichoptera with special reference to the Limnephilidae. Ph.D. Thesis, University of Toronto. $168 \mathrm{pp}$.

WILLIAMS, N. E. and G. B. WIGGINS

1981 A proposed setal nomenclature and homology for larval Trichoptera. In Moretti, G. P., ed., Proceedings of the Third International Symposium on Trichoptera, Perugia, Italy. Series Entomologica 20. The Hague, Junk, pp. 421-429.

WILLIAMS, N. E. and D. D. WILLIAMS

1979 Distribution and feeding records of the caddisflies (Trichoptera) of the Matamek River region, Quebec. Canadian Journal of Zoology 57:2402-2412. 






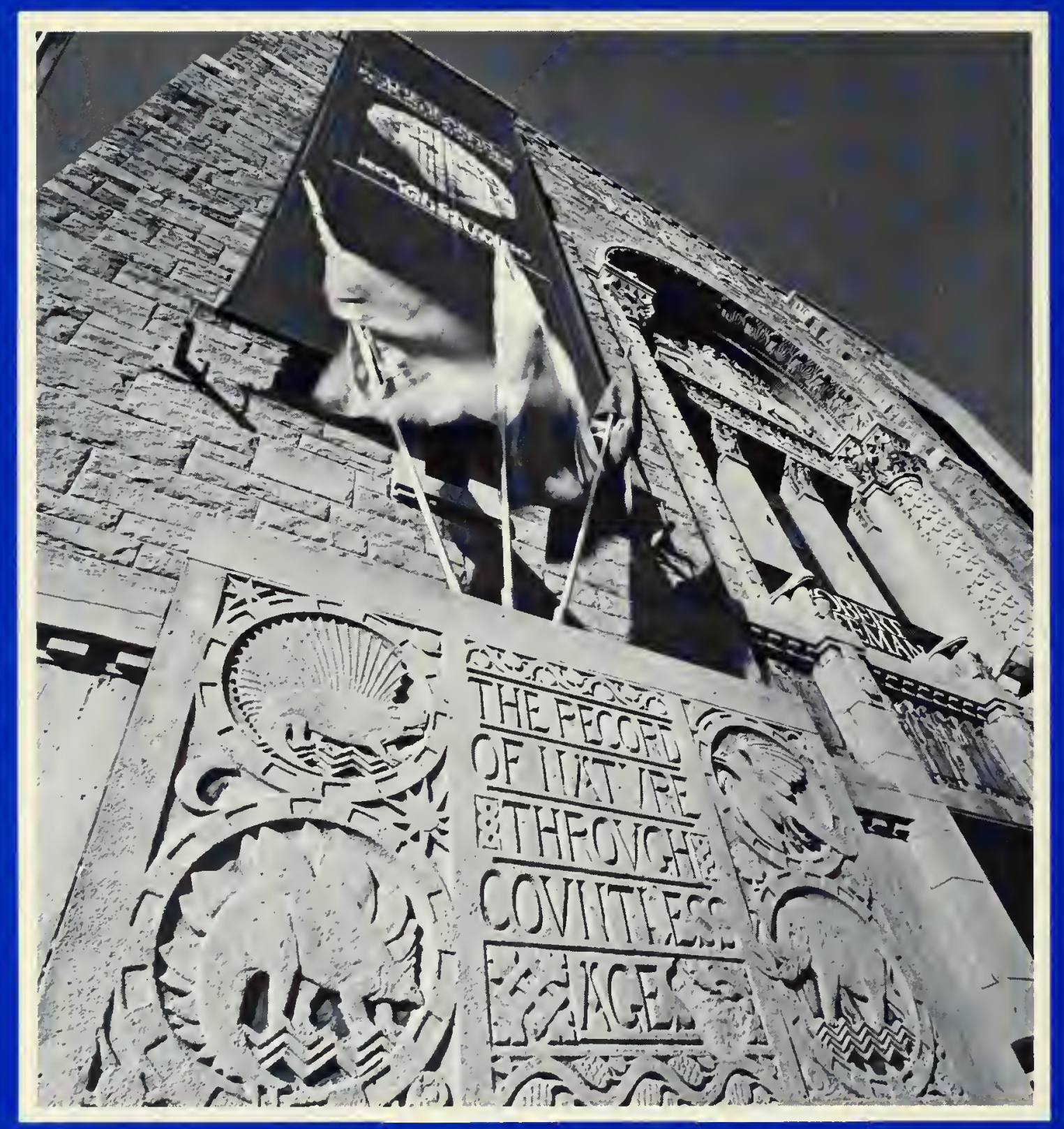

ISBN 0-88854-332-8

ISSN 0384-8159 